\title{
Hydrogeology and Water Resources of Ruby Valley, Northeastern Nevada
}

\author{
Prepared in cooperation with the \\ NEVADA DIVISION OF WATER RESOURCES \\ and the U.S. FISH AND WILDLIFE SERVICE
}

Scientific Investigations Report 2005-5247 
COVER: Ruby Valley looking northwest toward Ruby Lake National Wildlife Refuge and Ruby Mountains.

Photograph by David L. Berger, U.S. Geological Survey, 2001. 


\section{Hydrogeology and Water Resources of Ruby Valley, Northeastern Nevada}

By David L. Berger

Prepared in cooperation with the

NEVADA DIVISION OF WATER RESOURCES and the

U.S. FISH AND WILDLIFE SERVICE

SCIENTIFIC INVESTIGATIONS REPORT 2005-5247

U.S. Department of the Interior

U.S. Geological Survey 


\section{U.S. Department of the Interior \\ Gale A. Norton, Secretary \\ U.S. Geological Survey \\ P. Patrick Leahy, Acting Director}

\section{U.S. Geological Survey, Carson City, Nevada, 2006}

For more information about the USGS and its products:

U.S. Geological Survey, Information Services

Box 25286, Denver Federal Center

Denver, CO 80225

Telephone: 1-888-ASK-USGS

World Wide Web: http://www.usgs.gov/

Any use of trade, product, or firm names in this publication is for descriptive purposes only and does not imply endorsement by the U.S. Government.

Although this report is in the public domain, permission must be secured from the individual copyright owners to reproduce any copyrighted materials contained within this report.

Suggested citation:

Berger, D.L., 2006, Hydrogeology and water resources of Ruby Valley, northeastern Nevada: U.S. Geological Survey Scientific Investigations Report 2005-5247, 39 p., available at URL: <http://pubs.water.usgs.gov/sir2005-5247>. 


\section{Contents}

Abstract Introduction
Purpose and Scope
Previous Investigations
Acknowledgements
Description of Study Area
Physiography
Hydrogeologic Framework and Vegetation
Geologic History and Structural Setting
Areal Extent of Hydrogeologic Units
Precipitation
Runoff
Evapotranspiration
Ground Water
$\quad$ Sources and Movement
$\quad$ Recharge
Water Ouality

\section{Figures}

Figure 1. Map showing location and general features of the Ruby Valley area, northeastern Nevada and location of selected precipitation stations, evapotranspiration sites, and spring and streamflow discharge sites

Figure 2. Graphs showing annual precipitation, as percent departure from average (1971-2000) for selected precipitation stations and SNOTEL sites in and near Ruby Valley, northeastern Nevada

Figure 3. Map showing distribution of hydrogeologic units, faults, and depth to pre-Cenozoic basement rock, Ruby Valley, northeastern Nevada

Figure 4. Graph showing difference between measured and predicted average annual precipitation versus the predicted average annual precipitation for 18 stations in and near Ruby Valley, northeastern Nevada, 1971-2000

Figure 5. Map showing distribution of annual precipitation based on altitude-location relation, Ruby Valley, northeastern Nevada. 
Figure 6. Graph showing comparison of average annual precipitation for 18 stations in and near Ruby Valley, northeastern Nevada, 1961-90 and 1971-2000.

Figure 7. Graph showing Palmer drought severity index for northeastern Nevada, 1895-2004

Figure 8. Graphs showing $(A)$ relation of Franklin River daily average streamflow to Lutts Creek instantaneous streamflow and $(B)$ comparison between predicted streamflow and measured streamflow for Lutts Creek, Ruby Valley, northeastern Nevada

Figure 9. Map showing site number and depth to ground water, for selected wells in spring 2003, in and near Ruby Valley, northeastern Nevada

Figure 10. Hydrographs showing changes in water levels in selected wells in Ruby Valley, northeastern Nevada, 2000-03.

Figure 11. Map showing generalized ground-water levels in basin-fill deposits, spring 2003, in and near Ruby Valley, northeastern Nevada.....

Figure 12. Graph showing major ion composition of ground water sampled in and near Ruby Valley, northeastern Nevada 32

Figure 13. Graph showing relation between delta deuterium and logarithm of chloride concentrations in sampled water in and near Ruby Valley, northeastern Nevada .33

Figure 14. Graph showing relation of delta deuterium to delta oxygen-18 in sampled water from evapotranspiration, ground-water, spring, and surface-water sites in and near Ruby Valley, northeastern Nevada

\section{Tables}

Table 1. Average annual precipitation at sites in and near Ruby Valley, northeastern Nevada ......5

Table 2. Summary of hydrogeologic units, Ruby Valley, northeastern Nevada ................................8

Table 3. Site number, location, and type of data available for selected evapotranspiration, well, spring, and surface-water sites, Ruby Valley, northeastern Nevada.

Table 4. Range in average annual precipitation for Ruby Valley Hydrographic Area, northeastern Nevada.

Table 5. Results of varying location coefficients in equation 1 on the distribution of precipitation, Ruby Valley, northeastern Nevada.

Table 6. Computed or estimated annual streamflow, drainage area, and annual unit-area runoff for Franklin River, Lutts Creek, and Overland Creek, Ruby Valley, northeastern Nevada

Table 7. Estimated annual water budget for the Ruby Valley Hydrographic Area, northeastern Nevada

Table 8. Results of chemical analyses for water samples from selected evapotranspiration, well, spring and surface-water sites, Ruby Valley, northeastern Nevada. 
CONVERSION FACTORS AND VERTICAL DATUM

\begin{tabular}{|c|c|c|}
\hline Multiply & By & To obtain \\
\hline \multicolumn{3}{|c|}{ Length } \\
\hline inch (in.) & 2.54 & centimeter $(\mathrm{cm})$ \\
\hline foot (ft) & 0.3048 & meter $(\mathrm{m})$ \\
\hline mile (mi) & 1.609 & kilometer (km) \\
\hline acre-foot per square mile (acre-ft/mi²) & 476.25 & cubic meter per square kilometer $\left(\mathrm{m}^{3} / \mathrm{km}^{2}\right)$ \\
\hline \multicolumn{3}{|c|}{ Area } \\
\hline acre & 4,047 & square meter $\left(\mathrm{m}^{2}\right)$ \\
\hline \multicolumn{3}{|c|}{ Transmissivity* } \\
\hline $\begin{array}{r}\text { cubic foot per day per foot width of } \\
\text { aquifer }\left(\mathrm{ft}^{2} / \mathrm{d}\right)\end{array}$ & 0.09290 & $\begin{array}{l}\text { cubic meter per day per meter width of } \\
\text { aquifer }\left(\mathrm{m}^{2} / \mathrm{d}\right)\end{array}$ \\
\hline \multicolumn{3}{|c|}{ Flow rate } \\
\hline foot per day (ft/d) & 0.3048 & meter per day $(\mathrm{m} / \mathrm{d})$ \\
\hline foot per year (ft/yr) & 0.3048 & meter per year $(\mathrm{m} / \mathrm{yr})$ \\
\hline inch per year (in/yr) & 25.4 & millimeter per year (mm/yr) \\
\hline \multicolumn{3}{|c|}{ Volumetric rate } \\
\hline acre-foot per year (acre-ft/yr) & 1,233 & cubic meter per year $\left(\mathrm{m}^{3} / \mathrm{yr}\right)$ \\
\hline \multicolumn{3}{|c|}{ Hydraulic gradient } \\
\hline foot per mile (ft/mi) & 0.1894 & meter per kilometer $(\mathrm{m} / \mathrm{km})$ \\
\hline
\end{tabular}

Sea level: In this report, "sea level” refers to the National Geodetic Vertical Datum of 1929 (NGVD of 1929, formerly called "Sea-level Datum of 1929"), which is derived from a general adjustment of the first-order leveling networks of the United States and Canada.

Datum: Horizontal coordinate information is referenced to the North American Datum of 1983 (NAD83) unless otherwise stated.

Temperature: Degrees Celsius $\left({ }^{\circ} \mathrm{C}\right)$ can be converted to degrees Fahrenheit $\left({ }^{\circ} \mathrm{F}\right)$ by using the formula ${ }^{\circ} \mathrm{F}=\left(1.8 \mathrm{x}{ }^{\circ} \mathrm{C}\right)+32$.

*Transmissivity: The standard unit for transmissivity is cubic foot per day per square foot times foot of aquifer thickness $\left[\left(\mathrm{ft}^{3} / \mathrm{d}\right) / \mathrm{ft}^{2}\right] \mathrm{ft}$. In this report, the mathematically reduced form, foot squared per day $\left(\mathrm{ft}^{2} / \mathrm{d}\right)$, is used for convenience.

Water-quality units:

$\mathrm{mg} / \mathrm{L}$ milligrams per liter

$\mu \mathrm{g} / \mathrm{L} \quad$ micrograms per liter 


\title{
Hydrogeology and Water Resources of Ruby Valley, Northeastern Nevada
}

\author{
By David L. Berger
}

\section{Abstract}

Ruby Valley is a topographically closed, relatively undeveloped basin in northeastern Nevada that is experiencing slow but steady rural development. In 1999 the U.S. Geological Survey, in cooperation with the Nevada Division of Water Resources and the U.S. Fish and Wildlife Service, began a phased evaluation of the water resources in Ruby Valley. Phase 1 was completed in 2001 and provides evapotranspiration data from wetland habitats within the Ruby Lake National Wildlife Refuge. Phase 2 of the evaluation, presented in this report, was designed to provide information on the water resources of the entire Ruby Valley Hydrographic Area, including an updated water budget.

The distribution of precipitation in Ruby Valley, derived from four estimates, range from 700,000 acre-ft/yr (acre-feet per year) developed from the Hardman precipitation map of Nevada to 910,000 acre-ft/yr based on a relation among annual precipitation, altitude, and location developed for this study. Predictions based on the Hardman precipitation map estimates about 25 to 31 percent less precipitation than the other estimates. Most of the differences in total precipitation are related to differences in climatic conditions during the period of estimated precipitation. Annual runoff generated in the mountain blocks that border Ruby Valley ranges from about 82,000 to 100,000 acre-ft/yr. The Ruby Mountains and East Humboldt Range generate about 80 percent of the total runoff.

The depth to ground water in basin-fill deposits during the spring of 2003 ranged from less than 5 feet along the margins of Ruby Lake to more than $200 \mathrm{ft}$ beneath the alluvial slope in the northeast part of the valley. During the 4-year period from 2000 to 2003 water levels generally declined over much of the study area due to below average precipitation. Average ground-water recharge from precipitation is about $100,000 \mathrm{acre}-\mathrm{ft} / \mathrm{yr}$, based on basin-scale reconnaissance level methods. Water samples were collected from 16 wells and 11 springs in and near Ruby Valley and analyzed for major ions, nutrients, and stable-isotopic composition. No primary drinking-water standards were exceeded for any of the constituents that were analyzed. Secondary drinkingwater standards were exceeded for manganese, sulfate, iron, dissolved solids, and $\mathrm{pH}$ at three wells. Most of the water sampled is a calcium-bicarbonate type.
Total annual inflow to Ruby Valley ranges from about 710,000 to 930,000 acre-ft/yr. Precipitation makes up the largest inflow component. Subsurface inflow, from Huntington and Northern Butte Valleys, represent less than 2 percent of the total inflow. Estimates of total annual outflow range from 780,000 to 870,000 acre-ft/yr. Evapotranspiration (ET) represents the largest outflow and is subdivided into areas of the mountain block, alluvial slope, and valley floor. ET from mountain-block areas that border Ruby Valley is about 270,000 acre-ft/yr based on mass-balance calculations. Estimates of ET on alluvial slopes, where the only source of water is soil moisture from precipitation and infiltrated streamflow, is about 180,000 acre-ft/yr. Total ET on the Ruby Valley floor in 2001 ranges from about 330,000 to 420,000 acre- $\mathrm{ft} / \mathrm{yr}$ and is comprised from five different land-cover types. Subsurface outflow represents less than 1 percent of the outflow from Ruby Valley and takes place northeastward toward Clover Valley and possibly southwestward toward Long Valley.

\section{Introduction}

Nevada is experiencing one of the fastest population growth rates in the Nation. This growth is the driving force behind most present and emerging water-resources problems in the State. Ruby Valley is a relatively undeveloped and sparsely populated area in northeastern Nevada and currently the subject of water-right adjudication proceedings. In July 1985, the office of the Nevada State Engineer declared Ruby Valley a "Designated Basin," which limits the exercise of committed ground-water rights to not exceed a basin's estimated long-term recharge (Nevada Revised Statute 534.120, 2003).

Water resources in Ruby Valley were last evaluated more than 50 years ago by the U.S. Geological Survey (USGS; Eakin and Maxey, 1951) and provided a reconnaissance-level estimate of the ground-water budget. Since then additional climatic and hydrologic data have been collected and the development of remote-sensing techniques have provided new tools and approaches for water-resources analyses. This current study, made by the USGS in cooperation with the 
Nevada Division of Water Resources and the U.S. Fish and Wildlife Service was designed to evaluate the water resources of Ruby Valley, with emphasis on updating the water budget.

\section{Purpose and Scope}

This water-resources evaluation of Ruby Valley was divided into two 3-year phases. Phase 1 was designed to quantify annual evapotranspiration (ET) from the Ruby Lake National Wildlife Refuge (Ruby Lake NWR) for the 2000 water year (Berger and others, 2001). The 2000 water year is from October 1, 1999, to September 30, 2000. Presented in this report are the results of phase 2 of the overall investigation. This report presents information on the hydrogeologic framework and water resources of Ruby Valley, including an updated water budget and estimates of ground-water recharge.

\section{Previous Investigations}

One of the earliest water-resources investigations in Ruby Valley was done by the USGS in the late 1940's by Eakin and Maxey (1951). Their study briefly describes the hydrography of Ruby Valley and presents estimates of ground-water recharge and discharge. Other early studies of the USGS that provide information on Ruby Valley include a bulletin by Hill (1916) and a memorandum report on ground water by Taylor (1940). As part of a series of reconnaissance studies to provide preliminary appraisals of Nevada's water resources, Rush and Everett (1966) and Glancy (1968) provide estimates of subsurface inflow to Ruby Valley from adjacent basins. In a hydrogeologic appraisal of hydrothermal systems in northern and central Nevada, Olmsted and others (1975) provide information on the Sulphur Hot Springs thermal area in westcentral Ruby Valley. Several report products of the USGS Great Basin Regional Aquifer-System Analysis (RASA) included the Ruby Valley area. These RASA reports include Bedinger and others (1984), Thomas and others (1986), Harrill and others (1988), Prudic and others (1995), and Plume (1996). In addition, Nichols (2000) included Ruby Valley as part of a regional ground-water ET study of nearly $15,000 \mathrm{mi}^{2}$ in eastern Nevada.

Several reports by Sharp (1938, 1939a, 1939b, 1940, and 1942) and Howard (1966a,1966b, 1971, and 1980) included geology, geologic structure, and geomorphology of the Ruby Mountains and East Humboldt Range. Dudley (1967) used geomorphic features to infer the hydrogeology of the central Ruby Mountains and their influence on streamflow and ground-water movement. Chemistry of ground water in the carbonate rocks of the southern Ruby Mountains was described by Johnson (1980). A detailed discussion of the regional geology of Elko County, which includes most of Ruby Valley, is presented by Coats (1987). Geology of the southern part of Ruby Valley that lies in White Pine County is presented by Hose and Blake (1976). Csuti (1987) describes an ecological survey and assessment of land adjacent to
Franklin Lake in the north-central part of the valley. The last 40,000 years of environmental and climatic change, based on palynological data from sediment cores from Ruby Lake, are described by Thompson (1992).

As a result of phase 1 of the current overall USGS study in Ruby Valley, Berger and others (2001) present seasonal and annual ET rates for major habitats within the Ruby Lake NWR for the 2000 water year. Daily ET rates, miscellaneous streamdischarge and water-level measurements, and water-quality data collected as part of the overall Ruby Valley study have been published annually in data reports of the USGS (Allander and others, 2001; Garcia and others, 2002; Berris and others, 2003).

\section{Acknowledgements}

The author expresses appreciation to the many private land owners and residents who granted access to their property and provided descriptions of Ruby Valley history. Further gratitude is expressed to the personnel at the U.S. Fish and Wildlife Service stationed at the Ruby Lake NWR and the Gallagher State Fish Hatchery.

\section{Description of Study Area}

Ruby Valley is an elongated, topographically closed basin in northeastern Nevada, about $30 \mathrm{mi}$ southeast of Elko, Nev. (fig. 1). The valley occupies a north-south-trending structural basin in the Great Basin region of the Basin and Range physiographic province. The boundary of the Ruby Valley Hydrographic Area ${ }^{1}$ (HA; fig. 1), which coincides with the drainage-area boundary, encompasses about $1,000 \mathrm{mi}^{2}$ in Elko and White Pine Counties.

The residential population in the study area is distributed among several ranches around the north, northwest, and northeast sides of the valley. The principal industries are ranching, which is supported by large acreages of irrigated land, and recreational activities. On the basis of landsat imagery collected in 1985, 1989, 1995, and 2001 an average of about 4,300 acres of land were irrigated. Near the center of the valley is Franklin Lake, 3,200 acres of which are managed by the Nevada Division of Wildlife (fig. 1). The Ruby Lake NWR headquarters and Gallagher State Fish Hatchery are located along the east flank of the Ruby Mountains adjacent to Ruby Lake, in the southern part of the valley. Shantytown, a seasonal community, is about $3 \mathrm{mi}$ south of the refuge headquarters.

\footnotetext{
${ }^{1}$ The U.S. Geological Survey and Nevada Division of Water Resources delineated formal hydrographic areas in Nevada systematically in the late 1960's for scientific and administrative purposes (Cardinalli and other, 1968; Rush, 1968). The official hydrographic-area names, numbers, and geographic boundaries continue to be used in Geological Survey scientific reports and Division of Water Resources administrative activities. Hydrographic-area boundaries generally coincide with drainage-area boundaries.
} 


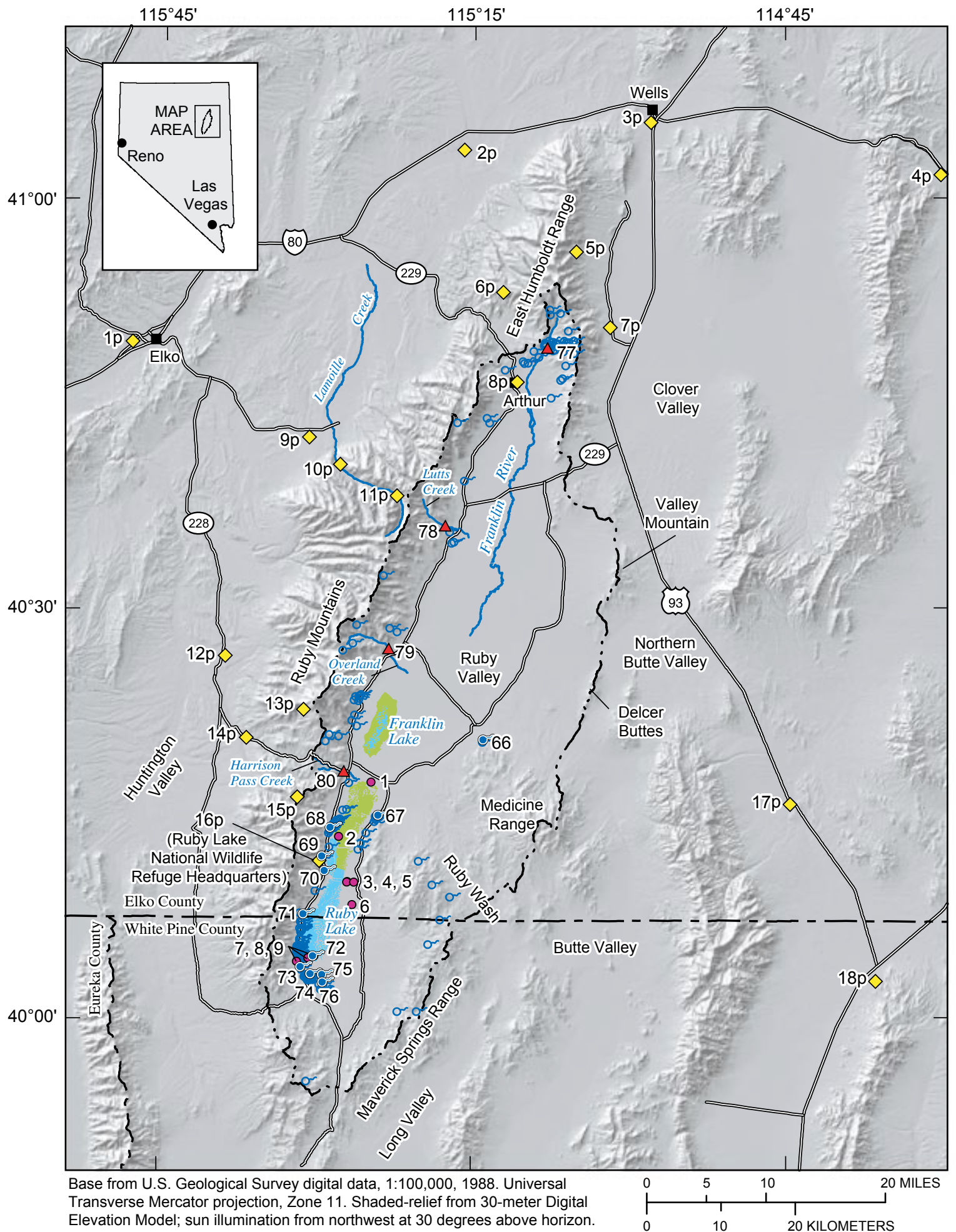

EXPLANATION

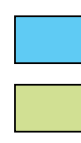

\begin{tabular}{|c|c|c|}
\hline Lake & $-\cdots-$ & $\begin{array}{l}\text { Ruby Valley hydrographic-area } \\
\text { boundary }\end{array}$ \\
\hline Wetland & & $\begin{array}{l}\text { Precipitation station- } \\
\text { Site number listed in table } 1\end{array}$ \\
\hline
\end{tabular}
2 - Evapotranspiration site-
Site number listed in table 3
76 Spring-measurement site- Site number listed in table 3

$80 \triangle$ Streamflow-discharge siteSite number listed in table 3 or Spring

Figure 1. Map showing location and general features of the Ruby Valley area, northeastern Nevada and location of selected precipitation stations, evapotranspiration sites, and spring and streamflow discharge sites. 


\section{Physiography}

The Ruby Mountains form the entire western border of Ruby Valley (fig. 1). This mountain range is a narrow, asymmetrical fault block that extends nearly $80 \mathrm{mi}$ to the south from its northern extension near Wells, Nev. Along nearly its entire length, the east slope of the Ruby Mountains is steeper than the west slope; in many places, the crest of the range is west of the drainage divide (Sharp, 1940, p. 343). Several peaks in the range have altitudes that exceed $11,000 \mathrm{ft}$. The Ruby Mountains merge in the north with the East Humboldt Range (fig. 1), which forms the north and northeast borders of the valley. Summit altitudes of the East Humboldt Range are between 8,000 and 11,000 ft. The Ruby Mountains and the East Humboldt Range are the most dominant features in the study area and are the principal source areas for inflow of water to Ruby Valley. The eastern border of the valley is composed of low hills and alluvial divides in the north and the Medicine and Maverick Springs Ranges (fig. 1), which reach altitudes of nearly $8,000 \mathrm{ft}$, in the south.

The floor of Ruby Valley lies just above an altitude of $5,900 \mathrm{ft}$, making it one of the higher valleys in the Great Basin. The valley is divided into two internally drained basins separated by an alluvial ridge at an altitude of about $6,000 \mathrm{ft}$. The lowest parts of these two basins are occupied by Franklin Lake in the north and Ruby Lake in the south. Wave action of the two lakes, aided by sediment from Harrison Pass Creek (fig. 1), probably built the alluvial ridge that separates the two lakes (Sharp, 1938, p. 318). The altitude of the valley floor increases northward from Franklin Lake to about 6,100 ft and southward from Ruby Lake to about 6,300 ft. Streams issuing from the east side of the Ruby Mountains north of Harrison Pass Creek and from the southwest flank of the East Humboldt Range, under natural conditions, terminate in Franklin Lake. The Franklin Lake drainage area covers the northern twothirds of the Ruby Valley HA. The existence of Franklin Lake is a result of accumulated precipitation and resultant streamflow from adjacent mountains (Csuti, 1987, p. 4). However, the Franklin River, which drains the southern part of the East Humboldt Range, flows to Franklin Lake only during sustained periods of above average precipitation. Streams south of and including Harrison Pass Creek and those issuing from the Maverick Springs Range terminate in Ruby Lake. Most of these streams are perennial only in the upper parts of the watersheds. Ruby Lake, in the southern third of Ruby Valley, is the site of the Ruby Lake NWR. The refuge covers nearly 38,000 acres of open water, wetland, and adjacent areas consisting of meadow, grassland, and shrub upland.

\section{Climate and Vegetation}

Ruby Valley is in a middle-latitude desert and steppe climate that is dominated by tropical air masses in the summer and continental polar air masses in the winter (Houghton and others, 1975, p. 13, 69-70). In the Ruby Mountains and East
Humboldt Range, average annual precipitation is about 33 in., based on Snowpack Telemetry (SNOTEL) data (1971-2000) from five stations (sites 5p, 6p, 11p, 13p, and 15p; fig. 1; table 1; Natural Resources Conservation Service, 2002). The Ruby Mountains and East Humboldt Range create a severe rain shadow and as a result precipitation abruptly decreases to the east. In addition, many storm tracks move southeast over southern Idaho and retain moisture until the Ruby Mountains and East Humboldt Range are encountered. Precipitation data collected at the headquarters of Ruby Lake NWR (site 16p; fig. 1) and at a weather station near Arthur, Nev. (site 8p; fig. 1), in the northern part of the valley indicate that average annual precipitation on much of the valley floor during the 30-year reference period (1971-2000) is about 14 in. (table 1). Farther east, annual precipitation on valley floors is about 8 in. (sites $4 p, 17 p$, and 18p; fig. 1; table 1).

Generally, precipitation throughout northeastern Nevada was below average during the period of this study (19992003). Annual precipitation on the valley floor of Ruby Valley was about 30 percent below the 30-year average (1971-2000) on the basis of data collected at Ruby Lake NWR and Arthur (sites 16p and 8p, respectively; fig. 2). Annual precipitation in the Ruby Mountains and East Humboldt Range, based on available data (1979-2003) recorded at two SNOTEL sites (site $6 p$ and $15 p$; fig. 2), indicate similar below average precipitation. The effects of below average precipitation in the study area appear to have been cumulative. The areal extent of flooded areas in the Ruby Lake NWR decreased from nearly 13,800 acres in the spring of 2000 to about 8,600 acres in the spring of 2004 (Jeffrey Mackay, U.S. Fish and Wildlife Service, oral commun., 2004).

Monthly precipitation on the floor of Ruby Valley generally is evenly distributed during October through May and averages about 1.34 in. monthly. During the remainder of the year monthly precipitation averages about $0.74 \mathrm{in}$., with the lowest amount typically recorded in July. In the Ruby Mountains and East Humboldt Range, average monthly precipitation during the period of October through May is more than twice that on the valley floor and represents the greatest source of inflow water to the valley.

Temperature data collected at Ruby Lake NWR (site 16p; 1971-2000) indicate that daily maximum temperatures in the summer typically exceed $85^{\circ} \mathrm{F}$ but reach $100^{\circ} \mathrm{F}$ on only 1 or 2 days during late July or early August. The average daily minimum summer temperature is about $40^{\circ} \mathrm{F}$. Daily maximum temperatures during the winter range between 30 and $50^{\circ} \mathrm{F}$ and daily minimum temperatures typically range from about 0 to $30^{\circ} \mathrm{F}$ but have been recorded as low as $-15^{\circ} \mathrm{F}$ in January. Annual evaporation (September 1999-October 2000) measured at an open-water site in the south marsh of Ruby Lake NWR was about 65 in. (site 7; fig. 1; Berger and others, 2001, p. 16). Pan-evaporation measurements collected at the refuge headquarters from 1978 through 2003 average about 48 in. from April through October (Jeffrey Mackay, U.S. Fish and Wildlife Service, written commun., 2004). 
Table 1. Average annual precipitation at sites in and near Ruby Valley, northeastern Nevada

\begin{tabular}{|c|c|c|c|c|c|c|c|}
\hline \multirow{2}{*}{$\begin{array}{c}\text { Site } \\
\text { number } \\
\text { (see fig. } \\
1 \text { for site } \\
\text { location) }\end{array}$} & \multirow[b]{2}{*}{ Station name } & \multirow[b]{2}{*}{$\begin{array}{l}\text { Available } \\
\text { period of } \\
\text { record }\end{array}$} & \multirow{2}{*}{$\begin{array}{l}\text { Altitude }{ }^{1} \text {, in } \\
\text { feet above } \\
\text { sea level }\end{array}$} & \multicolumn{2}{|c|}{$\begin{array}{c}\text { Average annual } \\
\text { precipitation, in inches }\end{array}$} & \multicolumn{2}{|c|}{$\begin{array}{l}\text { Estimated average annual } \\
\text { precipitation, in inches }\end{array}$} \\
\hline & & & & $1961-1990^{2}$ & $1971-2000^{2}$ & $\begin{array}{l}\text { PRISM }^{3} \\
\text { 1961-1990 }\end{array}$ & $\begin{array}{c}\text { Altitude- } \\
\text { location } \\
\text { relation }^{4} \\
\text { 1971-2000 }\end{array}$ \\
\hline $1 p$ & Elko WB airport & 1890-2004 & 5,196 & 9.93 & 9.59 & 11 & 11 \\
\hline $2 \mathrm{p}$ & Deeth 2 SW & 1951-2004 & 5,380 & 12.27 & 12.46 & 13 & 11 \\
\hline $3 p$ & Wells & 1948-2004 & 5,633 & 10.58 & 10.22 & 11 & 12 \\
\hline $4 p$ & Oasis & 1987-2004 & 5,977 & 6.7 & 8.11 & 11 & 12 \\
\hline $5 p$ & Hole-in-mountain & 1982-2004 & 7,693 & 33.6 & 35.0 & 30 & 29 \\
\hline $6 p$ & Dorsey Basin & 1979-2004 & 8,011 & 31.9 & 32.4 & 30 & 32 \\
\hline $7 p$ & Clover Valley & 1965-2004 & 5,793 & 14.07 & 14.42 & 13 & 12 \\
\hline $8 p$ & Arthur 4 NW & 1948-2004 & 6,213 & 15.10 & 14.85 & 17 & 16 \\
\hline $9 p$ & Lamoille Yost & 1975-2004 & 5,862 & 14.47 & 14.05 & 13 & 14 \\
\hline $10 \mathrm{p}$ & Lamoille PH & 1917-1972 & 7,152 & 20.09 & 18.81 & 22 & 25 \\
\hline $11 \mathrm{p}$ & Lamoille \#3 & 1981-2004 & 8,234 & 33.9 & 33.3 & 34 & 33 \\
\hline $12 p$ & Jiggs & 1948-1972 & 5,597 & 12.37 & 16.01 & 11 & 12 \\
\hline $13 p$ & Green Mountain & 1981-2004 & 8,247 & 32.9 & 32.5 & 34 & 32 \\
\hline $14 p$ & Jiggs 8 SSE ZAGA & 1978-2004 & 5,694 & 13.54 & 13.35 & 13 & 11 \\
\hline $15 p$ & Corral Canyon & 1979-2004 & 8,343 & 29.8 & 29.7 & 30 & 32 \\
\hline $16 \mathrm{p}$ & Ruby Lake & 1948-2004 & 6,473 & 13.26 & 13.66 & 17 & 16 \\
\hline $17 \mathrm{p}$ & Currie Highway station & $1961-1991$ & 5,797 & 7.24 & 7.27 & 9 & 7 \\
\hline $18 p$ & Lages & 1984-2004 & 6,085 & 7.70 & 7.90 & 9 & 7 \\
\hline
\end{tabular}

${ }^{1}$ Altitude based on 90 meter digital elevation model.

${ }^{2}$ Data from Natural Resources Conservation Service (2002) and National Oceanic and Atmospheric Administration (2002). Average annual precipitation for stations with incomplete years are estimated using a weighting function derived from observed relations between a candidate's monthly observations and those of up to 20 neighboring stations whose observations are most strongly correlated with the candidate site (Natural Resources Conservation Service, 2002, p. 3 ).

${ }^{3}$ Estimate based on May 1997 simulation of Precipitation-elevation Regression on Independent Slopes Model (PRISM; Daly and others, 1994).

${ }^{4}$ Estimate based on altitude-location relation (eq. 1) developed for this study. 

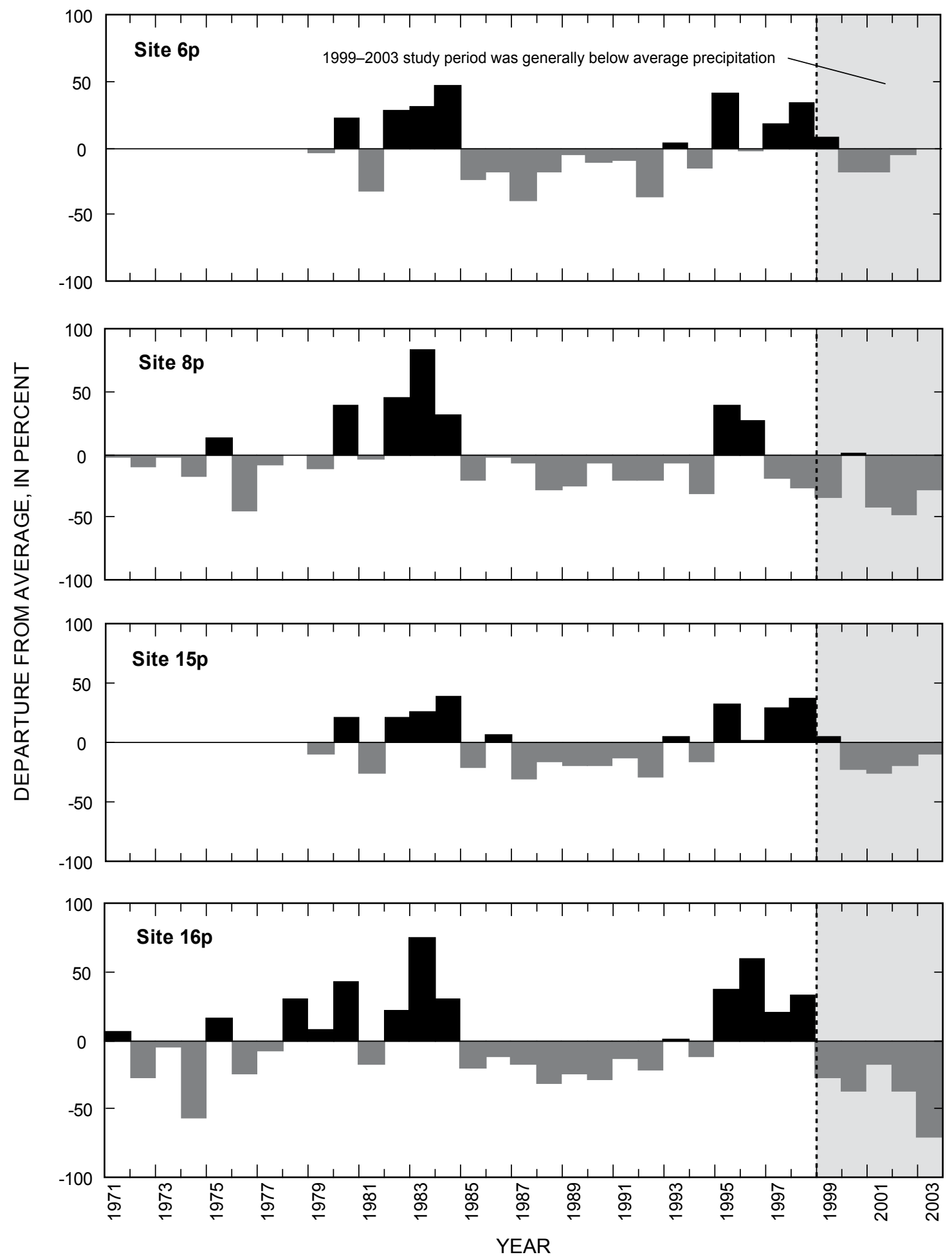

Figure 2. Graphs showing annual precipitation, as percent departure from average (1971-2000) for selected precipitation stations and SNOTEL sites in and near Ruby Valley, northeastern Nevada (National Oceanic and Atmospheric Administration, 2002; Natural Resources Conservation Service, 2002). See table 1 for site information. 
From about the middle to upper parts of the alluvial slopes that border the valley floor to nearly 9,000 $\mathrm{ft}$ in the surrounding mountains, the vegetation is characterized by a pinyon-juniper woodland assemblage (Charlet, 1996, p. 233). Sagebrush and grasses make up the understory of this assemblage and above about 7,500 ft mountain mahogany and aspen often are present, particularly along stream channels and in areas of ground-water seeps. Above 9,000 ft the subalpine zone includes whitebark pine, limber pine, Engleman spruce (only found in East Humboldt Range; Coats, 1987, p. 7), and aspen. Ancient bristlecone pines are found in the southern Ruby Mountains. The alpine-tundra zone is above about 11,000 ft (Nichols, 2000, p. C8).

The sagebrush community covers the lower parts of the alluvial slopes adjacent to the valley floor and in areas of the valley floor where the water table is greater than about $35 \mathrm{ft}$. This plant community is the largest in the study area. Several species of sagebrush are found in this community, including big, dwarf, and black. Spiny hopsage, bitterbrush, Morman tea, green rabbitbrush, and numerous species of grasses also are present.

In the lowlands of the valley, plants of the shadscalegreasewood and salt-desert communities are found. Phreatophytes, plants that have deep root systems and transpire water directly from the water table or capillary fringe above the water table, are included in these communities. Within the shadscale-greasewood community are shadscale, greasewood, basin wildrye, saltbrush, spiny hopsage, winterfat, big sage, and rabbitbrush. Greasewood is the principal phreatophyte and grows in areas where the depth to ground water ranges from about $5 \mathrm{ft}$ to nearly $35 \mathrm{ft}$ (Berger, 1995, p. 35). Along the margins of Franklin Lake and along the east side of Ruby Lake and other areas on the valley floor, picklewood, saltsage, and saltgrass make up the salt-desert community. Saltgrass is the most common phreatophyte of this community and grows in areas where depth to ground water is less than about $8 \mathrm{ft}$ (Nichols, 2000, p. C8). Wetlands of the Ruby Lake NWR consist of areas of open water that contain submerged aquatic vegetation as well as areas of moderate to dense bulrush and scattered stands of cattails. The wetlands are bordered by meadows in places where the water table rises periodically and causes flooding, or is very near the land surface. Riparian vegetation and grasses are found near springs and canals along the west side of the refuge as well as along stream channels in adjacent mountain blocks.

\section{Hydrogeologic Framework}

The geologic history that has shaped Ruby Valley is complex and includes periods of regional metamorphism, thick accumulations of sedimentary and volcanic rocks, major tectonic events, glaciation, and cyclic fluctuations of a large, closed-basin lake. The combination of geologic events and lithology greatly influences the hydrology of the study area by affecting the water-yield characteristics of the mountain blocks and controlling the movement of ground water. The more than two dozen geologic units recognized in the study area are grouped, using nomenclature modified from Maurer and others (2004a), into nine hydrogeologic units on the basis of lithology and hydrologic similarities. The hydrogeologic units are described in terms of geologic characteristics, occurrence, and general water-bearing properties in table 2 and the generalized hydrogeology of the study area and depth to pre-Cenozoic basement rock are shown in figure 3 .

\section{Geologic History and Structural Setting}

From as early as late Precambrian time to at least early Triassic time, the Ruby Valley area was within the miogeosynclinal belt of what was once the continental margin of North America (Stewart and Poole, 1974; Hose and Blake, 1976, p. 1; Stewart, 1980, p. 14-60). During that period, tens of thousands of feet of continental deposits and carbonate and shale sediments accumulated (Stewart, 1980, p. 14). Nearly $17,000 \mathrm{ft}$ of continuous Paleozoic rock, consisting mostly of dolomite and limestone, make up the southern Ruby Mountains, and form the carbonate hydrogeologic unit used in this report (fig. 3; Sharp, 1942, p. 651). These Paleozoic carbonate rocks exhibit karstic features such as sinkholes and solution channels. The Paleozoic rocks that comprise the northern part of the Ruby Mountains and East Humboldt Range have been subjected to regional metamorphism, which included intense recumbent folding and intrusion of granitic rocks (Howard, 1980 p. 336-337). Howard (1980, p. 335) describes the results of this regional metamorphism as a metamorphic-core complex which probably formed during the Jurassic(?) period. Granitic rocks of the Harrison Pass Pluton separate the metamorphic-core complex from the relatively simple structured Paleozoic rocks that comprise the southern part of the range.

The depositional environment in northeastern Nevada was disrupted by several tectonic events. The dominant disturbance was the Antler orogeny, which occurred during Late Devonian to early Early Mississippian time (Stewart, 1980, p. 36; Coats, 1987, p. 80). The most significant feature of the Antler orogeny was the Roberts Mountain thrust, which brought deep-water siliceous rocks eastward over shallowwater carbonate rocks of the same age (Stewart, 1980, p. 36). Although Ruby Valley lies east of Roberts Mountain thrust, the Antler orogeny created highlands that provided a depositional source of clastic material to many of the basins in the region, including Ruby Valley. A second period of intense tectonic activity, in the form of extensional faulting, took place in the late Tertiary. This extensional faulting is thought to have created the block-faulted basins and ranges that characterize the basin-and-range topography of today. The last major uplift of the Ruby Mountains and East Humboldt Range and most mountains that border Ruby Valley is thought to have occurred in late Pliocene to mid-Pleistocene time (Sharp, 1939a, p. 902-904). 
Table 2. Summary of hydrogeologic units, Ruby Valley, northeastern Nevada

[Composite description from Sharp (1939a, 1939b), Hose and Blake (1976), Stewart and Carlson (1978), and Coats (1987). Abbreviations: mi², square miles; ft, feet]

\begin{tabular}{|c|c|c|}
\hline Hydrogeologic unit ${ }^{1}$ (see fig. 3 ) & Geologic description & Occurrence and general hydrologic properties \\
\hline \multicolumn{3}{|c|}{ Cenozoic basin-fill deposits } \\
\hline Valley-floor deposits & $\begin{array}{l}\text { Moderate to well sorted unconsolidated sand and silt } \\
\text { with interbedded layers of clay. Playas unconsoli- } \\
\text { dated clay and silt. }\end{array}$ & $\begin{array}{l}\text { Occupies area of unconsolidated deposits with less } \\
\text { than } 3 \text { percent slope (Maurer and others, 2004a). } \\
\text { Comprises largest part of study area }\left(370 \mathrm{mi}^{2}\right) \text {. } \\
\text { Permeability moderate to low and tends to decrease } \\
\text { toward valley center. }\end{array}$ \\
\hline Alluvial-slope deposits & $\begin{array}{l}\text { Poorly to moderately sorted, unconsolidated sand, } \\
\text { gravel, and some silt. }\end{array}$ & $\begin{array}{l}\text { Occupies margin between valley floor and mountain } \\
\text { block }\left(290 \mathrm{mi}^{2}\right) \text {. Permeability high to moderate and } \\
\text { tends to decrease toward the valley floor. }\end{array}$ \\
\hline \multicolumn{3}{|c|}{ Cenozoic volcanic and sedimentary rocks } \\
\hline Tuffaceous rocks and sediments & $\begin{array}{l}\text { Light gray to white beds of ash and tuff in lower } \\
\text { part of section. Tuffaceous siltstone and sandstone, } \\
\text { conglomerate, claystone, and thinly bedded limestone } \\
\text { most abundant in upper half of section. Interbedded } \\
\text { with andesite, basaltic, and rhyolitic flows through- } \\
\text { out. Some beds have been altered to montmorillonite. }\end{array}$ & $\begin{array}{l}\text { Comprises much of northwest extension of Medi- } \\
\left.\text { cine Range ( } 42 \mathrm{mi}^{2}\right) \text { as scattered outcrops. Includes } \\
\text { large part of Humboldt Formation of Sharp (1939b). } \\
\text { Thickness at least 2,000 ft (Smith and Ketner, 1976, } \\
\text { p. B35) and may underlie much of valley floor (Sharp } \\
\text { 1939a, p. 894). Mostly fine grained and generally low } \\
\text { permeability. }\end{array}$ \\
\hline Andesitic flows & $\begin{array}{l}\text { Pyroxene andesite, hornblende rhyodacite, and bio- } \\
\text { tite-quartz latite. Basal unit typically white to green } \\
\text { tuffaceous clastic rock and pumice breccia. }\end{array}$ & $\begin{array}{l}\text { Large accumulation exposed in southern Maverick } \\
\text { Springs Range along basin boundary }\left(7 \mathrm{mi}^{2}\right) \text {. Other } \\
\text { isolated exposures occur in southern Ruby Mountains } \\
\text { and East Humboldt Range. Thickness at least } 2,000 \\
\mathrm{ft} \text { (Hose and Blake, 1976, p. 18). Generally the least } \\
\text { permeable of Cenozoic volcanic flows (Maurer and } \\
\text { others, 2004a). }\end{array}$ \\
\hline Volcanic breccias and tuffs & Medium gray to grayish red jasperoid breccia. & $\begin{array}{l}\text { Crops out as isolated exposures in extreme south- } \\
\text { ern part of Ruby Mountains and Maverick Springs } \\
\text { Range. Fills deep cuts in bedrock related to faults } \\
\text { (Hose and Blake, 1976, p. 22). Assumed to have low } \\
\text { permeability. }\end{array}$ \\
\hline
\end{tabular}




\begin{tabular}{|c|c|c|}
\hline Carbonate rocks & $\begin{array}{l}\text { Limestone, dolomite, and mixtures of limestone and } \\
\text { clastic rocks. }\end{array}$ & $\begin{array}{l}\text { Comprises most of the southern Ruby Mountains } \\
\text { (south of Harrison Pass Creek) and large part of } \\
\text { Maverick Springs and Medicine Ranges (total area } \\
168 \mathrm{mi}^{2} \text { ). Outcrops along west and south parts of East } \\
\text { Humboldt Range. Total thickness in Ruby Mountains } \\
\text { about 16,500 ft (Sharp, 1942, p. 651). Includes Ely } \\
\text { Limestone, Devils Gate, Nevada, and Lone Mountain } \\
\text { Formations, and Pogonip Limestone. Permeability } \\
\text { ranges from low in impure limestone to high due to } \\
\text { solution enlargement along joints. Secondary perme- } \\
\text { ability typically in direction of bedding (Dudley, } \\
\text { 1967, p. } 30-32 \text { ). }\end{array}$ \\
\hline \multicolumn{3}{|c|}{ Mesozoic and Cambrian-Precambrian sedimentary rocks } \\
\hline Clastic rocks & $\begin{array}{l}\text { Interbedded calcareous sandstone, sandy and shaley } \\
\text { limestone, shale, siltstone, quartzite, and conglomer- } \\
\text { ate. }\end{array}$ & $\begin{array}{l}\text { Crops out in northern part of Medicine Range and } \\
\text { central Ruby Mountains (north of Harrison Pass } \\
\text { Creek). Includes the Dinwoody and Thaynes Forma- } \\
\text { tions and Prospect Mountain Quartzite. Permeability } \\
\text { ranges from very low in quartzite to low in impure } \\
\text { limestone. }\end{array}$ \\
\hline
\end{tabular}

${ }^{1}$ Delineation of hydrogeologic units follows nomenclature presented by Maurer and others (2004a). 


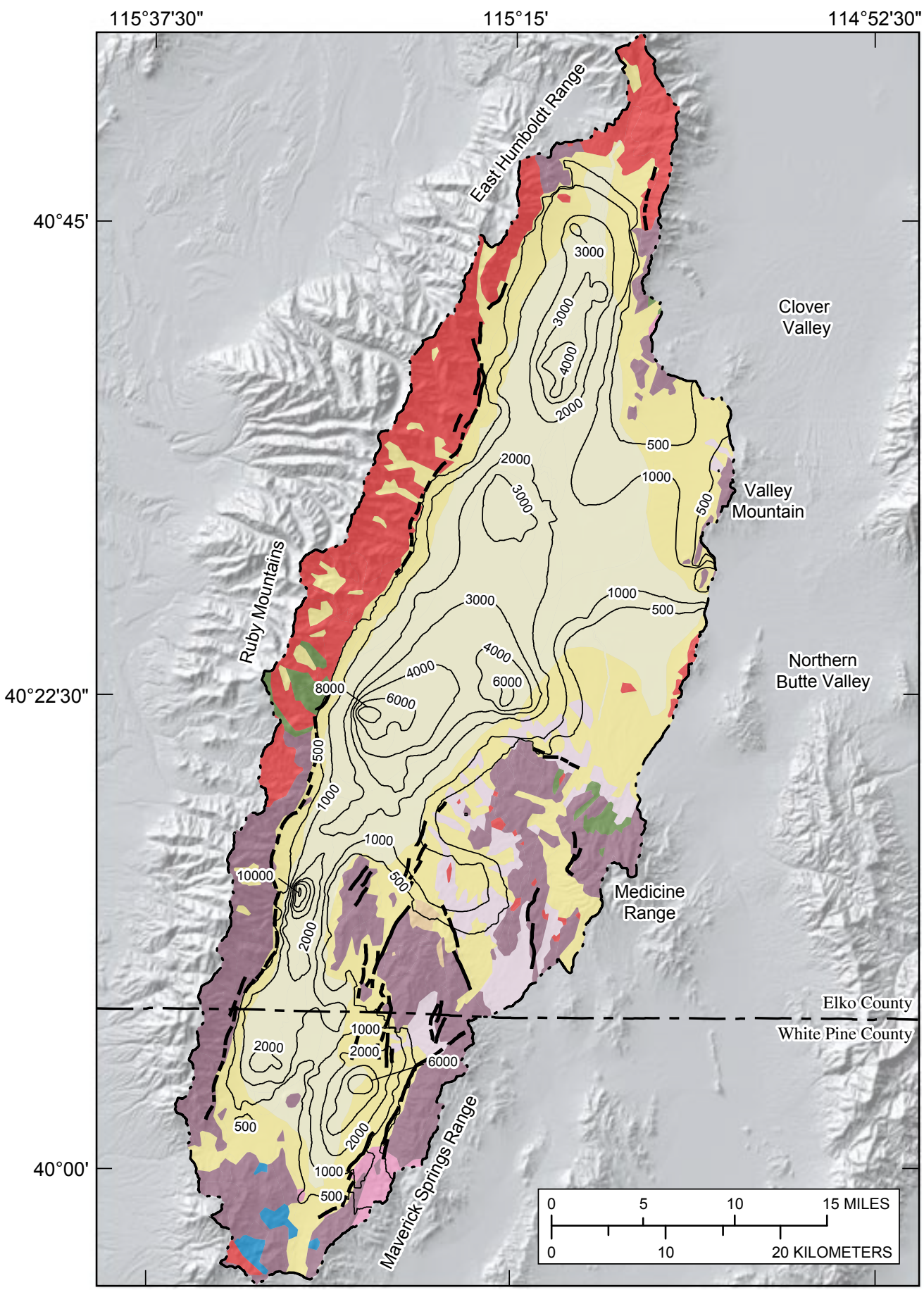

Base from U.S. Geological Survey digital data, 1:100,000, 1988. Universal Transverse Mercator projection, Zone 11. Shaded-relief from 30-meter Digital Elevation Model; sun illumination from northwest at 30 degrees above horizon.

\section{Hydrogeology}

Valley-floor deposits Alluvial-slope deposits

Tuffaceous rocks and sediments Rhyolitic flows

\section{EXPLANATION}

Delineation of hydrogeologic units from Maurer and others (2004a)

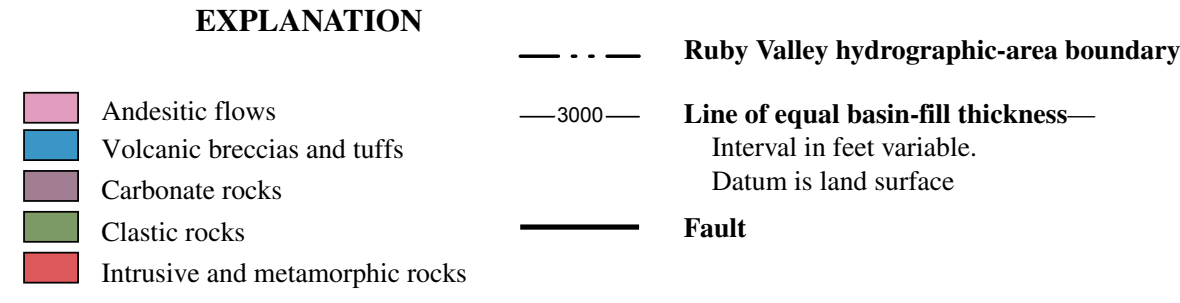

Figure 3. Map showing distribution of hydrogeologic units, faults, and depth to pre-Cenozoic basement rock, Ruby Valley, northeastern Nevada (modified from Maurer and others, 2004a). 
Accompanying the late Tertiary extensional tectonics, large volumes of detritus were eroded from adjacent mountain blocks and deposited in Ruby Valley and other down-dropped basins within the region. Designated as upper Tertiary sedimentary and volcanic rocks by Coats (1987, p. 62-63), these deposits include a large part of the Miocene Humboldt Formation (Sharp, 1939b, p. 133) and are grouped with the tuffaceous rocks in table 2 . The estimated thickness of the Tertiary sediments is several thousand feet and largely consist of semiconsolidated fluvial and lacustrine sedimentary rocks interbedded with andesite, basaltic and rhyolitic flows, ash, and associated tuffs (Sharp, 1939b; Smith and Ketner, 1976, p. B32; Stewart, 1980, p. 89). Results from an oil and gas exploration well indicate the Tertiary sediments are nearly $2,700 \mathrm{ft}$ thick near the center of the valley (Nevada Bureau of Mines and Geology, 2004). Sharp (1939b, p. 146) suggests that the Humboldt Formation and presumably other upper Tertiary sedimentary rocks rest directly on pre-Tertiary rocks and make up most of the Cenozoic basin-fill deposits that fill the structural basin beneath Ruby Valley. Eakin and Maxey (1951, p. 77) report that the Humboldt Formation was penetrated by a well at a depth of about $170 \mathrm{ft}$ in the northern part of Ruby Valley.

Large and frequent climatic fluctuations during the Quaternary period resulted in extensive glaciation and the development of large pluvial lakes in many of the basins in northeastern Nevada. During the Pleistocene (Wisconsin stage) two separate substages of glaciation took place in the northern Ruby Mountains and East Humboldt Range (Sharp, 1938). Pluvial Lake Franklin was synchronous with the glaciation and at its maximum extent covered about $480 \mathrm{mi}^{2}$ in Ruby Valley and the northern part of Butte Valley to a depth of about 115 ft (Mifflin and Wheat, 1979; Benson and Thompson, 1987, p. 247). Shorelines at an altitude of about $6,300 \mathrm{ft}$ indicate that an earlier Pleistocene lake that inundated the study area was nearly $300 \mathrm{ft}$ deep (Sharp, 1942, p. 685-686). Palynological data from sediment cores indicate that from about the middle Wisconsin $(40,000 \mathrm{yr}$ before present) to the middle Holocene (between 5,000 to 4,700 $\mathrm{yr}$ before present), the pluvial lakes in Ruby Valley cycled from shallow saline conditions and complete desiccation to a deep freshwater lake (Thompson, 1992). The overlying Pleistocene deposits are almost entirely clastic and are coarser and less consolidated than the underlying upper Tertiary sedimentary rocks (Eakin and Maxey, 1951, p. 75; Morrison, 1968, p. 874).

The most spectacular structural features within the study area are the escarpments associated with range-bounding faults along the east side of the Ruby Mountains (fig. 3). Repeated uplifts of the westward-tilted Ruby Mountains have produced vertical displacements of at least $6,500 \mathrm{ft}$ along the east boundary fault (Sharp, 1942, p. 687). Gravity data (David A. Ponce, U.S. Geological Survey, written commun., 2003) indicate depth to pre-Cenozoic basement may be $10,000 \mathrm{ft}$ east of the southern Ruby Mountains (fig. 3) suggesting the displacement probably is much greater than $6,500 \mathrm{ft}$. Although the surface expressions of the east boundary faults are buried near their southern end, the line of springs along Ruby Lake are evidence of the continuation of the faults (fig. 2).

The structural basin underlying Ruby Valley consists of a series of elongated grabens or depressions in the pre-Cenozoic basement rock (fig. 3). These depressions generally trend north-northeast and are structurally controlled by dip-slip boundary faults (Sharp 1939a, p. 898). The Cenozoic basinfill deposits and volcanic and sedimentary rocks that fill the structural basin, range in thickness from less than $500 \mathrm{ft}$ along the margins of the valley to about $10,000 \mathrm{ft}$ beneath the southcenter part of the valley (fig. 3).

\section{Areal Extent of Hydrogeologic Units}

Cenozoic basin-fill deposits are grouped into two hydrogeologic units: valley-floor deposits and alluvial-slope deposits (table 2; fig. 3). These units represent distinct geomorphic features and consist mostly of unconsolidated gravel and sand that readily transmit water. The valley-floor deposits, which cover about $370 \mathrm{mi}^{2}$, are defined as the area with a slope of less than 3 percent (fig. 3; Maurer and others, 2004a, p. 8). Included in the valley-floor unit are deposits of lacustrine origin that generally have low permeabilities. North of Delcer Buttes, valley-floor deposits extend into Northern Butte Valley along a low alluvial divide. Along the margin of the valley floor, between the consolidated rock of the mountain blocks and the valley-floor deposits, lay the alluvial-slope deposits. This unit covers about $290 \mathrm{mi}^{2}$ and consists of dissected pediments and alluvial fans (fig. 3). Unlike many basins in Nevada where alluvial slopes commonly have considerable thicknesses, the alluvial slopes in Ruby Valley, particularly along the east side of the Ruby Mountains, are comprised of thinly covered pediments (fig. 3; Sharp, 1940, p. 355).

Consolidated rocks, which form the mountain blocks and underlie the deposits that fill the valley, are grouped into seven hydrogeologic units (table 2). These units commonly have low permeability, with the exception of carbonate rocks, and do not readily transmit water except where fractured or along solution-enlarged joints and fissures. Outcrops of the carbonate unit cover nearly $170 \mathrm{mi}^{2}$ and make up the entire southern Ruby Mountains and much of the Maverick Springs Range and Valley Mountain (fig. 3). The existence of Ruby Lake and the associated wetland is due in large part to the highly permeable nature and stratigraphic position of the carbonate unit (Sharp, 1942, p. 685; Rush and Everett, 1966, p. 13). The water yield from the southern Ruby Mountains essentially has no streamflow component due to the enhanced permeability of the carbonate rocks, and as a consequence the eastward drainage is almost entirely made up of spring discharge (Dudley, 1967, p. 75; Johnson, 1980, p. 15-17; Thompson, 1992, p. 2).

The hydrogeologic characteristics of the carbonate unit are in sharp contrast to the characteristics of the intrusive and metamorphic unit that makes up the central and northern Ruby Mountains and much of the East Humboldt Range (fig. 3). These rocks, in part, have very low permeability, and typically act as barriers to ground-water movement. Relatively 
few springs issue from this hydrogeologic unit. Due to the relatively low permeability, streamflow makes up the largest component of the water yield from these areas (Dudley, 1967, p. 73).

The tuffaceous rocks and sediments unit makes up much of the Medicine Range (about $42 \mathrm{mi}^{2}$ ) and probably underlies much of the valley floor (Sharp, 1939a, p. 894). This unit mostly is semiconsolidated, fine- to coarse-grained deposits that generally have low permeability. Other hydrogeologic units within Ruby Valley are of lesser areal extent and include three units of Cenozoic volcanic rocks and one unit of clastic rocks ranging from Precambrian to the Mesozoic age. The Cenozoic volcanic rocks consist mostly of rhyolitic and andesitic flows, breccias, and tuffs. These units may develop some permeability along fractures and cooling joints, but typically are considered to have low permeability.

\section{Water Resources}

Most ground water in Ruby Valley originates as precipitation that falls within the drainage basin, either in the form of rain or snow. Precipitation typically increases with altitude, and tends to decrease eastward with distance from the Ruby Mountains. Streams that issue from the surrounding mountains either infiltrate to the ground-water system as they cross the alluvial slope, are consumed by ET, or continue flowing to Franklin or Ruby Lakes. Although Ruby Valley is a topographically closed basin, the ground-water system in Ruby Valley is not a closed system and is connected to adjacent basins to the east through basin-fill deposits. Table 3 lists site numbers, location, and type of data available for selected ET, well, spring, and surface-water sites used in this study.

Table 3. Site number, location, and type of data available for selected evapotranspiration, well, spring, and surface-water sites, Ruby Valley, northeastern Nevada

[Available data: ET, micrometeorological; GL, geophysical logs; Q, discharge; QW, water chemistry; WL, ground-water levels. Data from Allander and others (2001), Berger and others (2001), and Garcia and others (2002). Symbol: --, not available or unknown]

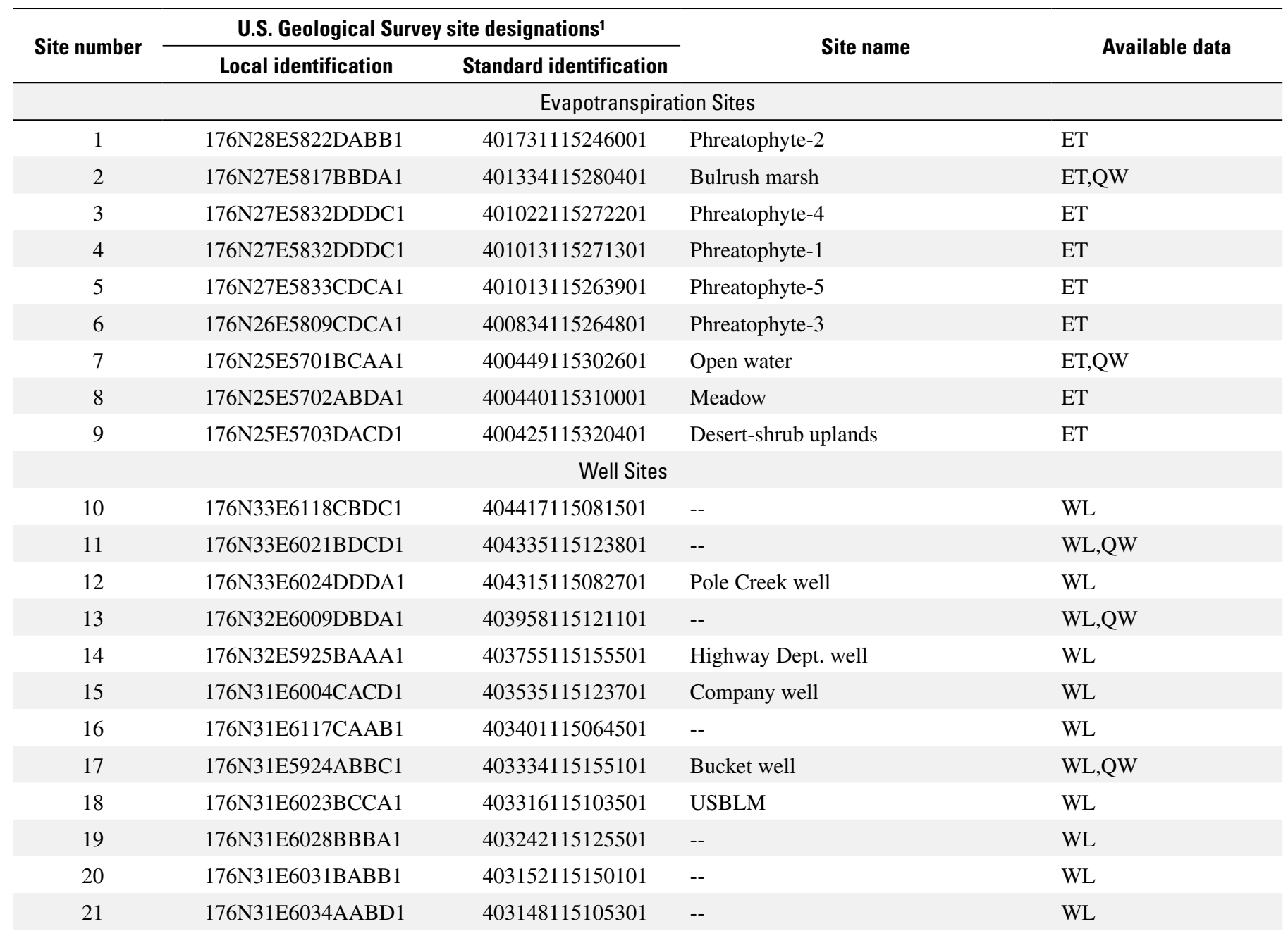


Table 3. Site number, location, and type of data available for selected evapotranspiration, well, spring, and surface-water sites, Ruby Valley, northeastern Nevada-Continued

\begin{tabular}{|c|c|c|c|c|}
\hline \multirow{2}{*}{ Site number } & \multicolumn{2}{|c|}{ U.S. Geological Survey site designations' } & \multirow{2}{*}{ Site name } & \multirow{2}{*}{ Available data } \\
\hline & Local identification & Standard identification & & \\
\hline \multicolumn{5}{|c|}{ Well Sites-Continued } \\
\hline 22 & 176N30E6005ABCD1 & 403050115134401 & South well & WL \\
\hline 23 & 176N30E6006ACAD1 & 403041115144101 & -- & WL \\
\hline 24 & 176N30 E6003DCBC1 & 403018115112901 & USBLM & WL \\
\hline 25 & 176N30E6002DDDD1 & 403013115095201 & -- & WL \\
\hline 26 & 176N30E6107DDDC1 & 402918115074301 & -- & WL \\
\hline 27 & 178AN30E6218CDCB1 & 402827115013601 & Dry Lake well & WL \\
\hline 28 & 176N30E5922DCAD1 & 402744115181001 & USBLM & WL \\
\hline 29 & 176N30E5928ABDC1 & 402724115192101 & River well & WL \\
\hline 30 & 176N30E5933CADB1 & 402607115193901 & -- & WL \\
\hline 31 & 178AN30E6233CACC1 & 402555114591801 & USBLM & WL,QW \\
\hline 32 & 176N29E6105BDBD1 & 402529115071201 & Frenchy well & WL \\
\hline 33 & 176N29E5915BBBC1 & 402360115190101 & Cross county windmill & WL,QW \\
\hline 34 & 176N29E6016BDBD1 & 402343115125801 & Basque well no. 2 & WL,QW \\
\hline 35 & 176N28E5804CBAC1 & 402010115265001 & Irrigation well & QW \\
\hline 36 & 176N28E5802CADA1 & 402001115241301 & -- & WL \\
\hline 37 & 176N28E5906DBDC1 & 402001115214601 & Stock well & WL \\
\hline 38 & 176N28E5809CBDB1 & 401913115265701 & -- & WL,QW \\
\hline 39 & 176N28E5909CDAA1 & 401900115200001 & Ruby Valley 1 & WL \\
\hline 40 & 176N28E5816CBAA1 & 401827115265601 & Irrigation well & WL \\
\hline 41 & 176N28E5917CACA1 & 401818115210001 & USBLM & WL \\
\hline 42 & 176N28E5815CCBB1 & 401813115255201 & Ruby Lake Estates 1 & WL,QW \\
\hline 43 & 176N28E5814DDCB1 & 401805115235401 & Stock well & WL \\
\hline 44 & 176N28E5822DBDA1 & 401728115250501 & USFWS & WL \\
\hline 45 & 176N28E5929DDBC1 & 401623115203101 & Stock well & WL \\
\hline 46 & 176N27E5806BADD1 & 401515115284901 & -- & WL,QW \\
\hline 47 & 176N27E5902DDBD1 & 401437115170401 & Ruby Wash well & WL \\
\hline 48 & 176N27E5910ABCD1 & 401417115182701 & Rock Cabin well & WL \\
\hline 49 & 176N27E5818BCCA1 & 401323115292801 & USFWS & WL \\
\hline 50 & 176N27E5828DBDD1 & 401121115262301 & USBLM & WL \\
\hline 51 & 176N26E5805ABAA1 & 401012115272901 & USFWS & WL \\
\hline 52 & 176N26E5810DDBB1 & 400838115251101 & USBLM & WL,QW \\
\hline 53 & 176N26E5816BBAA1 & 400827115265401 & USFWS & WL \\
\hline 54 & 176N25E5803DDBA1 & 400417115251901 & USBLM & WL,QW \\
\hline 55 & 176N25E5711BBBC1 & 400405115314901 & Fort Ruby Ranch 1 & WL,QW \\
\hline 56 & 176N25E5711BBBC2 & 400405115314902 & Fort Ruby Ranch 2 & WL \\
\hline 57 & 176N25E5711DADC1 & 400330115305101 & -- & WL \\
\hline 58 & 176N25E5714ADBB1 & 400301115305901 & -- & WL \\
\hline
\end{tabular}


Table 3. Site number, location, and type of data available for selected evapotranspiration, well, spring, and surface-water sites, Ruby Valley, northeastern Nevada-Continued

\begin{tabular}{|c|c|c|c|c|}
\hline \multirow{2}{*}{ Site number } & \multicolumn{2}{|c|}{ U.S. Geological Survey site designations ${ }^{1}$} & \multirow{2}{*}{ Site name } & \multirow{2}{*}{ Available data } \\
\hline & Local identification & Standard identification & & \\
\hline \multicolumn{5}{|c|}{ Well Sites-Continued } \\
\hline 59 & 176N25E5714ADBC1 & 400258115305901 & -- & $\mathrm{WL}$ \\
\hline 60 & 176N25E5714BDDC1 & 400252115312701 & Fort Ruby Ranch agriculture well & WL \\
\hline 61 & 176N25E5724BABB1 & 400222115302001 & -- & WL \\
\hline 62 & 176N25E5827BAAA1 & 400131115254501 & $\mathrm{RV}-2$ & WL,QW,GL \\
\hline 63 & 176N25E5829ABDC1 & 400119115274501 & -- & WL \\
\hline 64 & 176N25E5829ABDC2 & 400119115274801 & RV-1 shallow & WL,QW,GL \\
\hline 65 & 176N25E5829ABDC3 & 400119115274802 & RV-1 deep & WL,QW,GL \\
\hline \multicolumn{5}{|c|}{ Spring Sites } \\
\hline 66 & 176N27E6032CC 1 & 402039115141801 & Medicine Spring & QW \\
\hline 67 & 176N27E5802BD 1 & 401508115242201 & Hot Springs main pond east side & QW \\
\hline 68 & 176N27E5807BD 1 & 401412115285601 & 0.89 mi N Bressman Cabin & QW \\
\hline 69 & 176N27E5724DC 1 & 401205115301101 & Cave Spring & QW \\
\hline 70 & 176N27E5736AA 1 & 401105115292801 & Nino Spring at Fish Hatchery & QW \\
\hline 71 & 176N26E5714CD 1 & 400751115313001 & Spring at N County Line Pond & QW \\
\hline 72 & 176N25E5711DB 1 & 400450115303401 & Spring at south pond & QW \\
\hline 73 & 176N25E5711BB 1 & 400403115314701 & Fort Ruby Spring & QW \\
\hline 74 & 176N25E5711DD 1 & 400330115304801 & 1.09 mi SE Fort Ruby & $\mathrm{QW}$ \\
\hline 75 & 176N25E5712DD 1 & 400328115293801 & $0.64 \mathrm{mi}$ N Station Springs & QW \\
\hline 76 & 176N25E5713AD 1 & 400255115293801 & Station Springs at orifice & QW \\
\hline \multicolumn{5}{|c|}{ Surface-Water Sites } \\
\hline 77 & 176N34E6118CD 1 & 404925115081001 & Franklin River near Arthur & $\mathrm{Q}, \mathrm{QW}$ \\
\hline 78 & 176N31E5902BB 1 & 403610115172001 & Lutts Creek near Ruby Valley & Q \\
\hline 79 & 176N30E5823DD 1 & 402730115233001 & Overland Creek near Ruby Valley & Q \\
\hline 80 & 176N28E5817DB 1 & 401822115274001 & Harrison Pass Creek & $\mathrm{Q}, \mathrm{QW}$ \\
\hline
\end{tabular}

${ }^{1}$ Each U.S. Geological Survey data-collection site is assigned a unique identification on the basis of geographic location. For convenience, short site numbers (1-80) also are used for sites discussed in this report. A local site designation is used to identify a site by hydrographic area (Rush, 1968) and by the official rectangular subdivision of the public lands referenced to the Mount Diablo basde line and meridian. Each site designation consists of four units. The first unit is the hydrographic area number. The second unit is the township, preceded by " $\mathrm{N}$ " to indicate location north of the base line. The third unit is the range, preceded by "E" to indicate location east of the meridian. The fourth unit consists of the section number and letters designating the quarter section, quarter-quater section and so on (A, B, C and D indicate the northeast, northwest, southwest, and southeast quarter, respectively), following by a number indicating the sequence in which the site was recorded.

The standand identification is based on the grid system of latitude and longitude. The number consists of 15 digits. The first six digits denote the degrees, minutes, and seconds of latitude; the next seven digits denote the dgrees, minutes, and seconds of longitude; and the lst two digits (assigned sequentially) identify the sites within a 1-second grid. The assigned number is retained as a permanent identifier even if a more precise latitude and longitude are later determined. 


\section{Precipitation}

The distribution of annual precipitation in Ruby Valley (table 4) was previously estimated by Eakin and Maxey (1951) and Nichols (2000). Eakin and Maxey (1951, p. 80) estimated precipitation to be about 700,000 acre-ft/yr on the basis of the 1936 precipitation map of Nevada developed by Hardman (1936). The Hardman (1936) precipitation map was prepared from weather-station data correlated with data on altitude, general topography, latitude, and types of vegetation (Hardman and Mason, 1949, p. 54). Hardman (1936) found that the areal extent of native vegetation was a good indicator of the amount of annual precipitation. Accordingly, the Hardman precipitation map represents a long-term estimate of the distribution of annual precipitation prior to about 1934 (Hardman and Mason, 1949, p. 54).

Nichols (2000, p. C20) used the results from the May 1997 version of the computer model called Precipitationelevation Regression on Independent Slopes Model (PRISM; Daly and others, 1994) and estimated average precipitation in the study area to be about 870,000 acre- $\mathrm{ft} / \mathrm{yr}$. PRISM is designed to estimate and distribute precipitation at regional scales and represents average annual precipitation for the 30-year period (1961-90). For comparison purposes the PRISM data set used by Nichols was reanalyzed using a more accurately defined boundary (1:24,000 scale compared to the original 1:750,000 scale) for the hydrographic area of Ruby Valley. The revised PRISM estimate of 880,000 acre-ft/yr (table 4 ) is only about 1 percent different from the original estimate of Nichols (2000, p. C20), and probably is within the error associated with these estimates. However, both PRISM estimates are about 25 percent greater than the earlier estimate developed by Eakin and Maxey (1951).

To include more recent and local precipitation data and to resolve the rain-shadow effect created by the Ruby Mountains and East Humboldt Range, a relation between average annual precipitation, and station altitude and location was developed for the study area. Average annual precipitation over the 30-year period (1971-2000) for 18 stations in and near Ruby Valley (fig.1; table 1) was used in the development of the following regression equation:

$$
\begin{gathered}
P_{\text {ave }}=(E)\left(-6.76 \times 10^{-5}\right)+(N)\left(5.48 \times 10^{-5}\right)+ \\
(A)(0.0082)+(-33.92)
\end{gathered}
$$

where

$P_{a v e}$ is average precipitation (1971-2000), in inches per year;

$E$ is easting location of precipitation station relative to site $10 \mathrm{p}$ in east direction, in meters;

$N$ is northing location of precipitation station relative to

site $10 \mathrm{p}$ in north direction, in meters; and

$A$ is altitude of precipitation station, in feet.

The estimate of average precipitation using equation 1 is about 910,000 acre-ft/yr (table 4). Precipitation and location data for the 18 stations were obtained from the National Oceanic and Atmospheric Administration $(2002,2005)$. Altitude data for each station and as input to equation 1 were derived from a 90-meter digital elevation model (U.S. Geological Survey, 2001). The location of site 10p (easting $629574 \mathrm{~m}$; northing $4504520.32 \mathrm{~m}$ ) was used as the reference point in determining easting and northing locations. The coefficient of determination $\left(r^{2}=0.913\right)$ for equation 1 indicates that about 91 percent of the variance in annual precipitation at the selected stations can be explained by the regression relation. The residual plot shown in figure 4 indicates little evidence of structure and that residuals are nearly normally distributed; thus, the relation between average annual precipitation, and station altitude and location used in this analysis is acceptable. The distribution of precipitation in the area of study based on equation 1 is shown in figure 5 . Annual precipitation estimated for the mountain blocks that make up the eastern border of the study area likely is over estimated using equation 1 . The accuracy of equation 1 above about $8,300 \mathrm{ft}$, the altitude of the highest station used in the relation, is unknown. Regardless of these uncertainties, equation 1 provides an estimate of average annual precipitation that incorporates recent data collected in and near Ruby Valley.

Estimates of precipitation commonly are made based on the relation between station altitude and annual precipitation. The Ruby Mountains and East Humboldt Range create a significant rain shadow on the distribution of precipitation in the area of study. Varying the coefficients (slopes) of the easting and northing variables in equation 1 was used to determine the importance of incorporating station location in estimating the distribution of precipitation in Ruby Valley (table 5). Increasing the rain-shadow effect by doubling the easting and northing coefficients results in about a 7 percent decrease in total precipitation and lowers the $\mathrm{r}^{2}$ value to about 0.86 (table 5). Reducing the coefficients by half, diminishes the rain-shadow effect, increases total precipitation by about 4 percent, and slightly lowers the $\mathrm{r}^{2}$ value to about 0.89 . Varying the coefficients of the location variables only has a small effect on the estimate of total precipitation; however, the distribution of precipitation is affected greatly. Doubling the coefficients creates unreasonably low estimates of precipitation in the lower altitudes, which represents the largest area in Ruby Valley. Reducing the coefficients by half increases precipitation in the low-altitude area, but leads to unreasonably low precipitation in the higher altitudes of the Ruby Mountains and East Humboldt Range.

The resultant estimate of average annual precipitation using equation 1 predicts about 4 percent more precipitation than the PRISM estimates (table 4) and about 31 percent more than estimated by Eakin and Maxey (1951, p. 80). Although the PRISM estimates and the results of equation 1 represent different 30-year periods (1961-90 compared to 1971-2000), average annual precipitation at the 18 stations for those two periods generally are similar (fig. 6). Most of the differences in total precipitation between the estimate of Eakin and Maxey (1951, p. 80) and the other estimates are related to differences in climatic conditions during the period of estimated precipitation. 


\begin{tabular}{|c|c|c|c|c|c|c|c|c|}
\hline \multirow{2}{*}{$\begin{array}{l}\text { Precipitation } \\
\text { range, in inches }\end{array}$} & \multicolumn{2}{|c|}{ Eakin and Maxey (1951, p. 80) } & \multicolumn{2}{|c|}{ Nichols (2000, p. C50) } & \multicolumn{2}{|c|}{$\begin{array}{c}\text { Revised Precipitation-elevation } \\
\text { Regression on Independent Slopes } \\
\text { Model (PRISM) }\end{array}$} & \multicolumn{2}{|c|}{ Altitude-location relation (eq. 1) } \\
\hline & $\begin{array}{c}\text { Area, } \\
\text { in acres }\end{array}$ & $\begin{array}{c}\text { Estimated precipitation, } \\
\text { in acre-feet }\end{array}$ & $\begin{array}{c}\text { Area, } \\
\text { in acres }\end{array}$ & $\begin{array}{c}\text { Estimated precipitation, } \\
\text { in acre-feet }\end{array}$ & $\begin{array}{c}\text { Area, } \\
\text { in acres }\end{array}$ & $\begin{array}{c}\text { Estimated precipitation, } \\
\text { in acre-feet }\end{array}$ & $\begin{array}{c}\text { Area, } \\
\text { in acres }\end{array}$ & $\begin{array}{c}\text { Estimated precipitation, } \\
\text { in acre-feet }\end{array}$ \\
\hline $8-12$ & 372,400 & 310,000 & 161,395 & 161,870 & 162,358 & 162,332 & 176,046 & 175,365 \\
\hline $12-15$ & 126,100 & 142,900 & 240,590 & 279,195 & 241,563 & 280,268 & 219,774 & 250,524 \\
\hline $15-20$ & 82,500 & 120,000 & 144,181 & 209,517 & 150,185 & 218,011 & 124,183 & 183,359 \\
\hline$>20$ & 58,900 & 122,800 & 92,769 & 216,641 & 92,541 & 216,210 & 126,629 & 299,922 \\
\hline Total (rounded) & 640,000 & 700,000 & 639,000 & 870,000 & 647,000 & 880,000 & 647,000 & 910,000 \\
\hline
\end{tabular}

${ }^{1}$ The U.S. Geological Survey and Nevada Division of Water Resources delineated formal hydrographic areas in Nevada systematically in the late 1960's for scientific and administrative purposes (Cardinalli and other, 1968; Rush, 1968). The official hydrographic-area names, numbers, and geographic boundaries continue to be used in Geological Survey scientific reports and Division of Water Resources administrative activities. Hydrographic-area boundaries generally coincide with drainage-area boundaries.

Table 5. Results of varying location coefficients in equation 1 on the distribution of precipitation, Ruby Valley, northeastern Nevada

\begin{tabular}{|c|c|c|c|c|c|c|}
\hline Equation 1 & Easting coefficient ${ }^{1}$ & Northing coefficient ${ }^{1}$ & $\begin{array}{l}\text { Altitude } \\
\text { coefficient }\end{array}$ & Intercept & $\begin{array}{c}\text { Coefficient of } \\
\text { determination } \\
\left(\mathbf{r}^{2}\right)\end{array}$ & $\begin{array}{c}\text { Change }^{2} \text {, } \\
\text { in percent }\end{array}$ \\
\hline Best fit & $-6.764 \times 10^{-5}$ & $5.485 \times 10^{-5}$ & 0.00818 & -33.92 & 0.913 & 0 \\
\hline Increase rain-shadow effect & $-1.353 \times 10^{-4}$ & $1.097 \times 10^{-4}$ & 0.00822 & -32.70 & 0.858 & 93 \\
\hline Decrease rain-shadow effect & $-3.382 \times 10^{-5}$ & $2.742 \times 10^{-5}$ & 0.00816 & -34.53 & 0.894 & 104 \\
\hline
\end{tabular}

${ }^{1}$ Location of site 10p (fig.1, table 1) is used as a reference point (easting $629574 \mathrm{~m}$; northing $4504520.32 \mathrm{~m}$ ).

${ }^{2}$ Percent change from precipitation derived from best fit. 


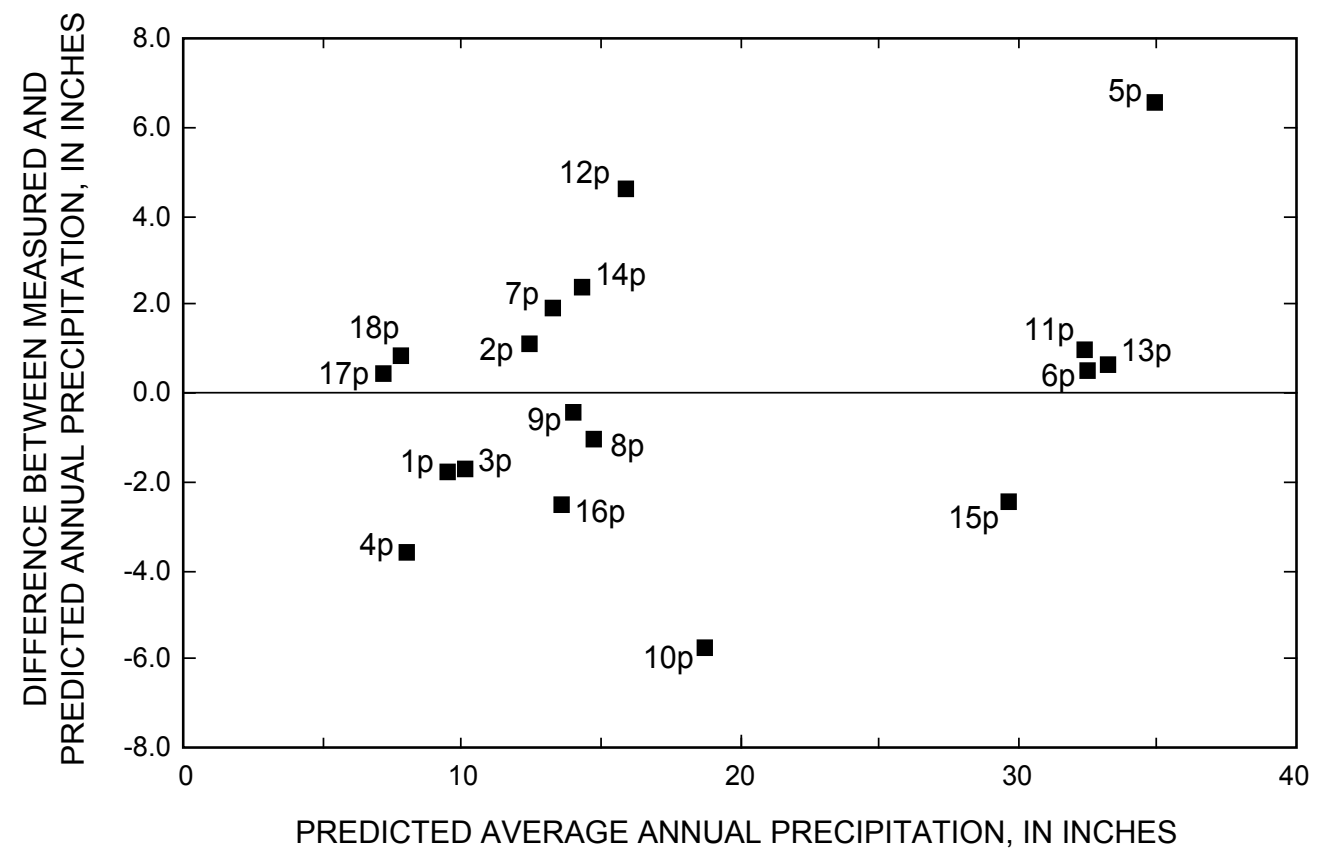

Figure 4. Graph showing difference between measured and predicted average annual precipitation versus the predicted average annual precipitation for 18 stations in and near Ruby Valley, northeastern Nevada, 1971-2000. See table 1 and figure 1.

The Palmer Drought Severiy Index (PDSI) responds to long-term weather conditions and provides a cursory indication of regional meteorological wet or dry periods (National Oceanic and Atmospheric Administration, 2005). The period of record used in the development of the Hardman precipitation map generally was prior to about 1934 (Hardman and Mason, 1949, p. 54). The PDSI indicates dry conditions dominated the period from about 1915 through 1939 in northeastern Nevada, with severe to extreme drought conditions occurring from 1924 through 1940 (fig. 7). Reconstruction of precipitation in northeastern Nevada from tree-ring data indicate that 1934 was the driest year since at least 1600 (Smith, 1986, p. 1257).

In comparison, the PDSI for the two 30-year periods (1961-90 and 1971-2000) indicate somewhat wetter conditions (fig. 7). The effect of these different climatic conditions are represented, in part, by differences in areas associated with particular precipitation zones (table 4). The area estimated by Eakin and Maxey $(1951$, p. 80$)$ to receive 8 to $12 \mathrm{in} / \mathrm{yr}$ is two times larger than the other estimates. In addition, the area estimated by Eakin and Maxey (1951, p. 80) to receive more than $20 \mathrm{in} / \mathrm{yr}$ is considerably less and the average amount of precipitation in that zone is about $3 \mathrm{in} / \mathrm{yr}$ less than the other estimates.

\section{Runoff}

For purposes of estimating runoff, watersheds are grouped in subareas on the basis of annual precipitation, water-yield characteristics, and hydrogeology. Streams in mountains that form the eastern border of the study area, mainly the southern extension of the East Humboldt Range, Valley Mountain, Delcer Buttes, Medicine Range, and Maverick Springs Range (fig. 1) are ephemeral and flow reaches the valley floor only during exceptionally wet seasons or after periods of intense rainfall. Because of the intermittent flow and small size of the eastern drainage areas, these streams probably contribute relatively small amounts of inflow to the ground-water system. In the carbonate terrain of the southern Ruby Mountains, streamflow largely is nonexistent due to the solution enlargement along joint fractures which enhances infiltration (Rush and Everett, 1966, p. 13; Dudley, 1967, p. 74; Johnson, 1980, p. 16). However, numerous streams issue to Ruby Valley from the northern Ruby Mountains and East Humboldt Range. Many of these streams are perennial and often reach the valley floor, where much of the water is diverted and used for irrigation.

Streamflow data in the area of study generally are sparse; however, continuous gaged streamflow data are available for Franklin River and Overland Creek (fig. 1; table 3; sites 77 and 79, respectively). Periodic streamflow measurements also are available for Franklin River, Lutts Creek, Overland Creek, and Harrison Pass Creek (fig. 1; table 3; sites 77, 78, 79 , and 80 ). The data from the gaged streams and the periodic measurements have been previously published in the USGS annual series "Water Resources Data for Nevada."

The Franklin River is the principal watershed that drains the southern flank of the East Humboldt Range and has a drainage area of about $11.1 \mathrm{mi}^{2}$ (site 77; fig. 1). Average annual discharge from the Franklin River for 19 years 


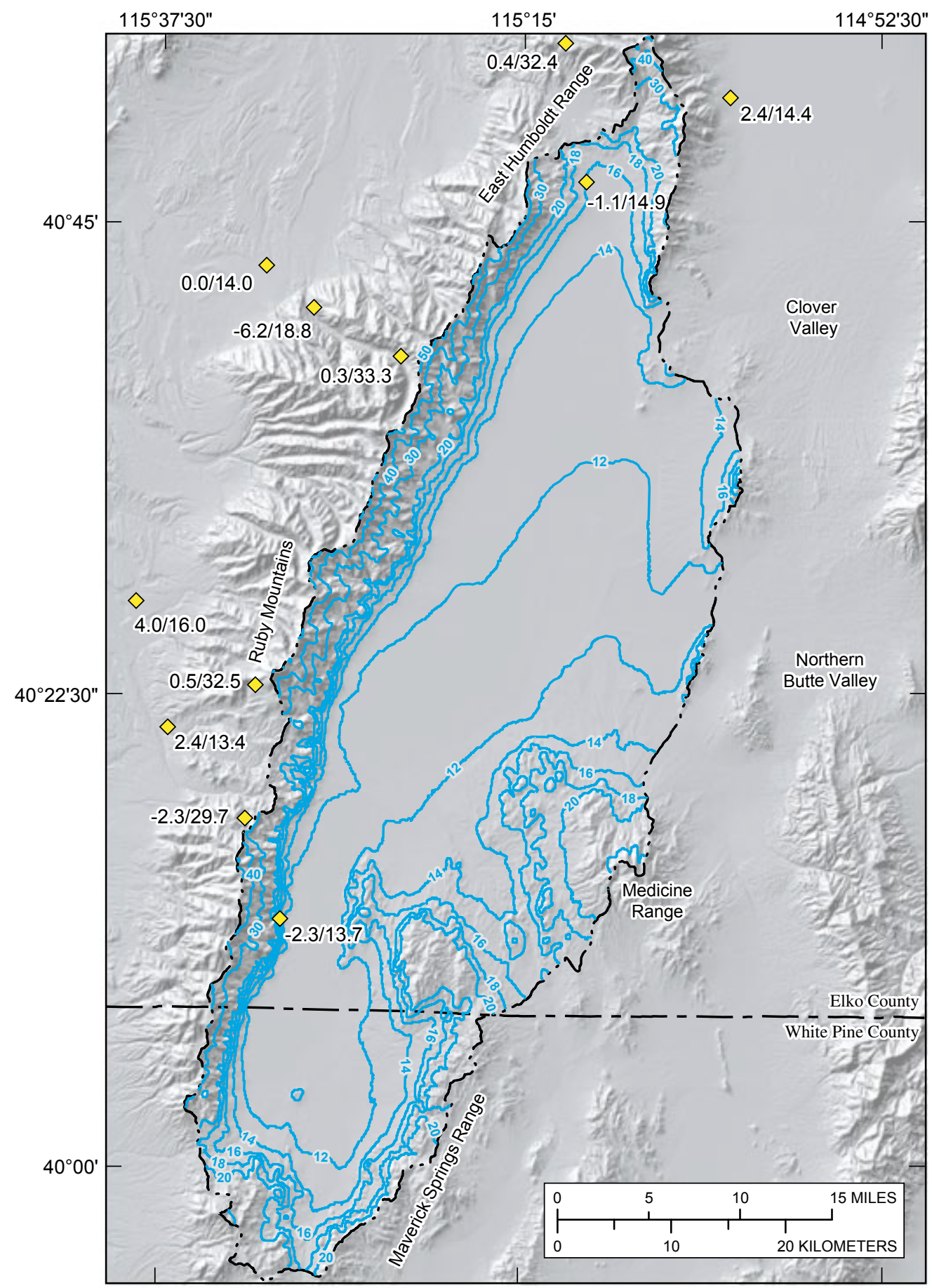

Base from U.S. Geological Survey digital data, 1:100,000,

1988. Universal Transverse Mercator projection, zone 11.

Shaded-relief from 30-meter Digital Elevation Model; sun

illumination from northwest at $\mathbf{3 0}$ degrees above horizon.

\section{EXPLANATION}

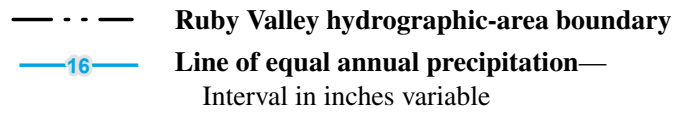

$-2.3 / 13.7^{\diamond}$

Precipitation station-First number is difference between measured and predicted precipitation, in inches; second number is average precipitation, 1971-2000

Figure 5. Map showing distribution of annual precipitation based on altitude-location relation, Ruby Valley, northeastern Nevada (derived from eq. 1). 


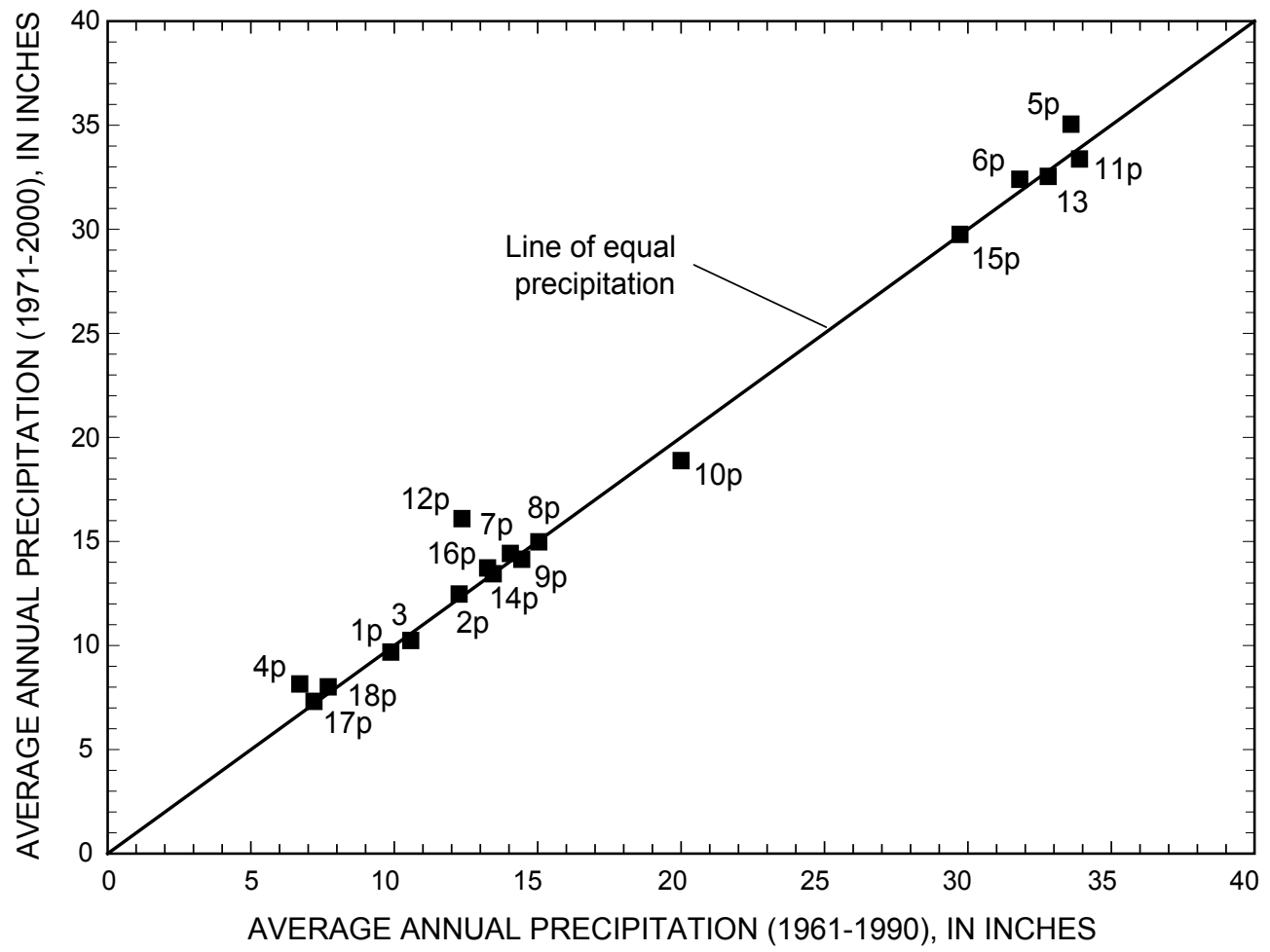

Figure 6. Graph showing comparison of average annual precipitation for 18 stations in and near Ruby Valley, northeastern Nevada, 1961-90 and 1971-2000. See table 1 and figure 1.

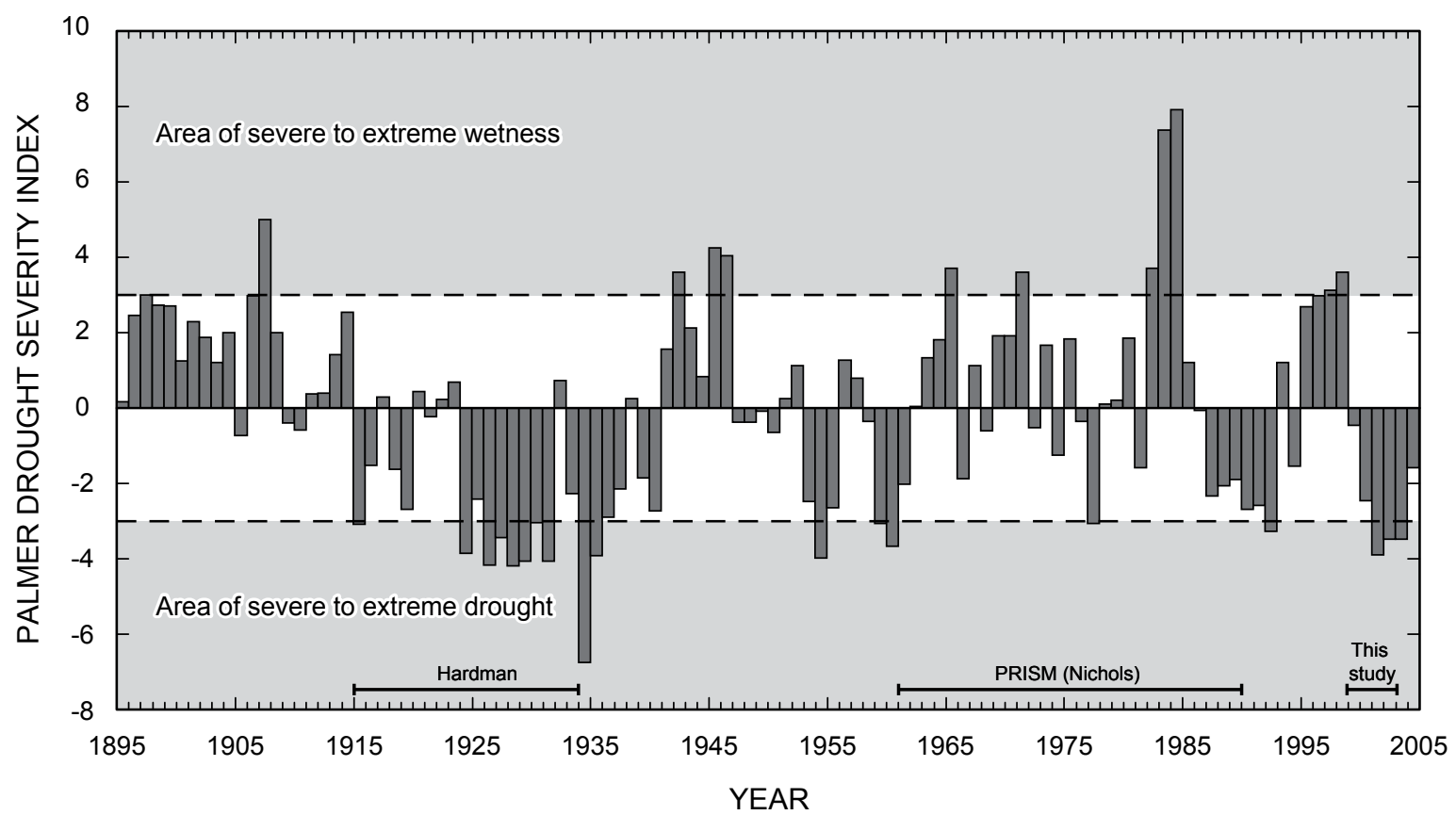

Figure 7. Graph showing Palmer drought severity index for northeastern Nevada, 1895-2004 (National Oceanic and Atmospheric Administration, 2005). 
Table 6. Computed or estimated annual streamflow, drainage area, and annual unit-area runoff for Franklin River, Lutts Creek, and Overland Creek, Ruby Valley, northeastern Nevada

\begin{tabular}{|c|c|c|c|c|}
\hline $\begin{array}{l}\text { Watershed } \\
\text { (see fig. 1) }\end{array}$ & $\begin{array}{c}\text { Station } \\
\text { identification } \\
\text { number }{ }^{1}\end{array}$ & $\begin{array}{l}\text { Drainage area, } \\
\text { in square miles }\end{array}$ & $\begin{array}{c}\text { Average annual } \\
\text { streamflow, } \\
\text { in acre-feet }\end{array}$ & $\begin{array}{l}\text { Annual unit-area runoff, } \\
\text { in acre-feet per square } \\
\text { miles, rounded }\end{array}$ \\
\hline Franklin River (site 77) & 10244720 & 11.1 & $8,260^{2}$ & 740 \\
\hline Lutts Creek (site 78) & 10244650 & 7.5 & $7,130^{3}$ & 950 \\
\hline \multirow[t]{2}{*}{ Overland Creek (site 79) } & 10244745 & 9.1 & $8,190^{2}$ & 900 \\
\hline & & & Average (rounded) & 860 \\
\hline
\end{tabular}

(1965-83) is about 8,260 acre-ft/yr. Although Franklin Lake is the terminus for the Franklin River, flow of the river typically infiltrates to the water table or is used for irrigation in the northern part of the valley before reaching the lake. Overland Creek, which drains the east side of the Ruby Mountains near the center of the valley, has a drainage area of about $9.1 \mathrm{mi}^{2}$ (site 79; fig. 1). Average discharge from Overland Creek for 13 years (1960-67 and 1977-81) is about 8,190 acre-ft/yr (table 6).

Lutts Creek also drains the east side of the northern Ruby Mountains and has a drainage area of about $7.5 \mathrm{mi}^{2}$ (site 78; fig. 1). Although Lutts Creek does not have continuous streamflow data, about 90 miscellaneous streamflow measurements are available over a 20-year period (1964-83). Gaged streamflow data (daily mean) from Franklin River that coincides in time with individual flow measurements from Lutts Creek were used to derive an estimate of annual streamflow for Lutts Creek for the period of 1964-83 (fig. 8). Based on the relation shown in figure $8 A$, average annual streamflow for Lutts Creek is about 7,130 acre-ft/yr (table 6). The coefficient of determination $\left(\mathrm{r}^{2}=0.913\right.$; fig. $\left.8 \mathrm{~A}\right)$ for this relation indicates that about 91 percent of the variance in streamflow at Lutts Creek can be explained by the relation with Franklin River shown in figure $8 \mathrm{~A}$. Comparison of predicted streamflow with measured streamflow (fig. $8 B$ ) indicates the relation predicts annual streamflow for Lutts Creek reasonably well for the period of record (1964-83).

The Ruby Mountains, north from about Harrison Pass Creek and the southern flank of the East Humboldt Range (fig. 1), generate the greatest amount of surface-water runoff in the study area. About 61 individual watersheds, encompassing about $105 \mathrm{mi}^{2}$, make up this area and range in drainage area from less than 0.1 to about $11.1 \mathrm{mi}^{2}$. Of these 61 watersheds, about 21 (about $18 \mathrm{mi}^{2}$ ) do not extend to the mountain crest and most are ephemeral. To estimate annual runoff from the northern Ruby Mountains and East Humboldt Range, estimates of annual unit-area runoff were derived on the basis of data from Franklin River, Lutts Creek, and Overland Creek. Annual unit-area runoff was calculated by dividing the computed or estimated annual streamflow, in acre-feet per year, by drainage area, in square miles. Annual unit-area runoff for the three watersheds ranged from about 740 to 950 acre-ft $/ \mathrm{mi}^{2}$ and averaged about $860 \mathrm{acre}-\mathrm{ft} / \mathrm{mi}^{2}$ (table 6).

Applying the estimated range of unit-area runoff to the drainage area of the 40 perennial watersheds (about $87 \mathrm{mi}^{2}$ ) results in about 64,000 to 83,000 acre-ft of annual runoff from the northern Ruby Mountains and East Humboldt Range. Maurer and others (2004b, p. 17) assumed that unit-area runoff from ephemeral watersheds along the east slope of the Carson Range in western Nevada is about half that of perennial watersheds. The Carson Range, which is part of the Sierra Nevada, consists mostly of granitic rock with low permeability where the water yield is dominated by surfacewater runoff, similar to the northern Ruby Mountains and East Humboldt Range. Applying an annual unit-area runoff of $430 \mathrm{acre}-\mathrm{ft} / \mathrm{mi}^{2}$, about half of the average of the perennial watersheds, results in about 7,700 acre-ft of annual runoff from ephemeral watersheds. Combining the runoff estimates for perennial and ephemeral watersheds in the northern Ruby Mountains and East Humboldt Range results in a range of runoff to Ruby Valley of 72,000 to $91,000 \mathrm{acre}-\mathrm{ft} / \mathrm{yr}$. The east side of the northern Ruby Mountains contributes about 59,000 to 74,000 acre-ft/yr of this total. In comparison, Rush and Everett (1966, p. 17), using the method of Riggs and Moore (1965), estimated runoff from the west side of the northern Ruby Mountains to be about 124,000 acre-ft/yr. Runoff from the east side of the northern Ruby Mountains is about 50 to 60 percent of the estimated runoff generated on the west side.

Streamflow in the southern Ruby Mountains, Medicine Range, Maverick Springs Range, and the southern extension of the East Humboldt Range is ephemeral. Because of this and the lack of runoff data, estimates of surface-water runoff for these areas are presented cautiously. Dudley (1967, p. 77) noted that during spring runoff many streams that drain the east side of the southern Ruby Mountains can carry a fair amount of flow, but by the end of June the streams are dry. During the course of the current study (1999-2003), however, no streamflow was observed to reach Ruby Lake. Most of the runoff is lost to infiltration as the stream traverses highly permeable carbonate rock and alluvial-slope deposits 

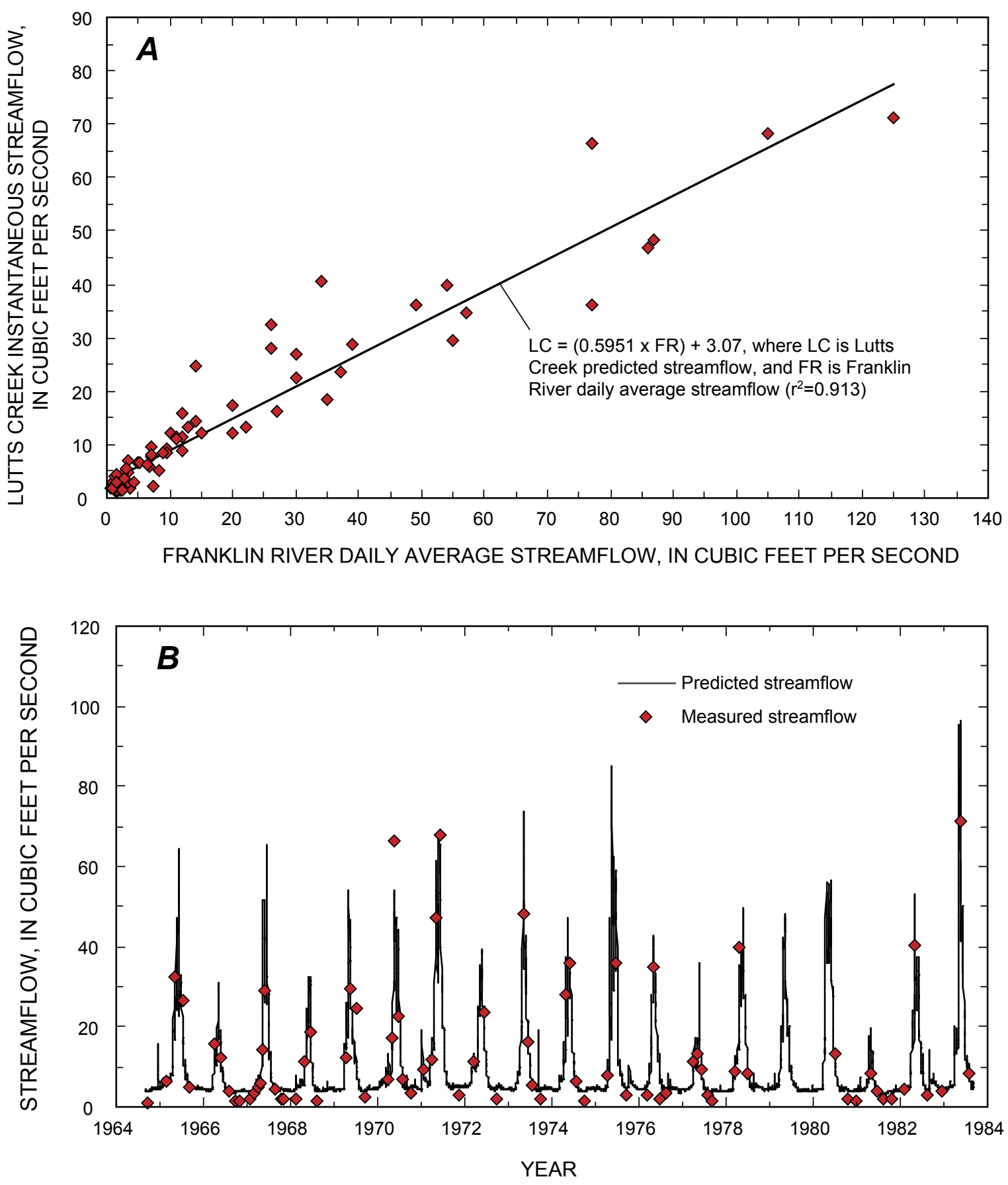

Figure 8. Graphs showing $(A)$ relation of Franklin River daily average streamflow to Lutts Creek instantaneous streamflow and $(B)$ comparison between predicted streamflow and measured streamflow for Lutts Creek, Ruby Valley, northeastern Nevada. 
and as a result contributes relatively large amounts of inflow to the ground-water system (Dudley, 1967, p. 78). The 29 watersheds that make up the southern Ruby Mountains cover about $40.7 \mathrm{mi}^{2}$, of which about $39.2 \mathrm{mi}^{2}$ (27 watersheds) extend to the mountain crest and receive more than $40 \mathrm{in}$. of annual precipitation. Applying a unit-area runoff of 430 acre-ft $/ \mathrm{mi}^{2}$, half of the estimated perennial unit-area runoff, to the watershed area in the southern Ruby Mountains results in about 18,000 acre-ft/yr of runoff. Most likely this value is unreasonably high when compared to the runoff estimate of 13,000 acre-ft/yr for the west side of the southern Ruby Mountains (Rush and Everett, 1966, p. 17). Using similar runoff ratios (about 50 to 60 percent), as those observed between the east and west drainages of the northern Ruby Mountains, a more reasonable estimate for runoff for the southern Ruby Mountains may range from 9,000 to 10,000 acre-ft/yr.

Runoff from the mountain blocks that form the eastern boundary of the study area (Medicine Range, Maverick Springs Range, and the southern extension of the East Humboldt range) is unknown and likely is small. The watersheds in these mountain blocks have a combined area of about $70 \mathrm{mi}^{2}$ of relatively low altitude area that lies in the rain shadow of the Ruby Mountains and as a result receive significantly less precipitation than the Ruby Mountains and East Humboldt Range. Glancy (1968, p. 17) reports that only ephemeral streamflow takes place from the east side of the Medicine Range. Maurer and others (2004b, p. 17) estimate that ephemeral drainages on the east side of Carson Valley have a combined unit-area runoff of about $24 \mathrm{acre}-\mathrm{ft} / \mathrm{mi}^{2}$. The Carson Range acts as a rain shadow to mountain blocks farther east, similar to the Ruby Mountains. The estimate of Maurer and others (2004b, p. 17) is very similar to the 21 acre$\mathrm{ft} / \mathrm{mi}^{2}$ estimated by Glancy (1968, p. 21) for the northeastern flank of the Medicine Range and southeastern flank of Valley Mountain in Northern Butte Valley (fig. 1). For computational purposes, a range of 20 to $25 \mathrm{acre}-\mathrm{ft} / \mathrm{mi}^{2}$ was applied to the watersheds along the eastern side of the study area and results in about 1,400 to 1,800 acre-ft/yr of runoff. Combining all estimates, total runoff to Ruby Valley from mountainblock areas ranges from 82,000 to 100,000 acre-ft/yr. For comparison, a runoff relation developed in mountain-block areas of north-central Nevada (Berger, 2000a, p. 14, eq. 1) was applied to the mountain-block areas in Ruby Valley and resulted in about 110,000 acre-ft of annual runoff.

The estimated annual runoff from the northern Ruby Mountains and East Humboldt Range accounts for nearly 50 percent of the annual precipitation that falls in those areas. This is similar to that of the Lamoille Creek watershed, which drains the west side of the northern Ruby Mountains (Berger, 2000a, p. 15). Average annual precipitation at available stations in and near the study area over the 20-year period (1964-83) of available streamflow data (sites 1p, 3p, 8p, and 16p; fig. 1) was about 5 to 6 percent greater than the average annual for two 30-year periods (1961-90 and 1971-2000). The range in annual runoff derived from unit-area calculation may represent an above average range. The percent of precipitation that becomes runoff in the southern Ruby Mountains is estimated to be about 15 percent. The remaining precipitation is either consumed by evapotranspiration and sublimation or infiltrates and recharges the ground-water system. Surfacewater runoff generated in the northern Ruby Mountains and East Humboldt Range represent about 80 percent of the total runoff to the area of study.

\section{Evapotranspiration}

The amount of water lost through ET is an important consideration in describing the water resources of Ruby Valley. ET represents the largest outflow and for this study was subdivided into several individual components. Measurements of ET and sublimation are not available for mountain-block areas in northeastern Nevada. Berger (2000a; 2000b) used a mass-balance approach between precipitation and water yield to estimate ET in mountain-block areas in north-central Nevada. A method to estimate average annual water yield for watersheds in western Nevada (Maurer and Berger, 1997, p. 32) was modified to include areas in north-central Nevada (Berger, 2000a, p. 15) and used in this study to estimate about 150,000 acre-ft/yr of water yield from mountain-block areas in Ruby Valley. From equation 1, about 420,000 acre-ft/yr of precipitation falls on mountain-block areas in Ruby Valley of which about 270,000 acre-ft/yr is lost to ET and sublimation. The remainder of the precipitation either contributes to runoff or infiltrates and provides inflow to the ground-water system as recharge.

The estimated rate of ET on alluvial slopes in the area of study, where the only source of water is soil moisture from precipitation and infiltrated streamflow, is 180,000 acre-ft/yr (table 7). Micrometeorological data collected on an alluvial slope in southern Ruby Valley (site 9; fig. 1) indicate that during the 2000 water year, ET was about $12.0 \mathrm{in} / \mathrm{yr}$ (Berger and others, 2001, p. 16). Additional micrometeorological data collected in low hills that border the Truckee River basin and an alluvial fan in western Nevada indicate ET ranges from about 11.0 to $18.0 \mathrm{in} / \mathrm{yr}$ (Carl Thodal and Mary Tumbusch, U.S. Geological Survey, written commun., 2005; Maurer and others, in press). As part of a water-budget evaluation of 14 hydrographic areas in north-central Nevada, Berger (2000a; 2000b) reports that ET on alluvial slopes may range from 9.0 to $12.0 \mathrm{in} / \mathrm{yr}$, depending on altitude and precipitation. Annual precipitation, in part, appears to be the limiting factor for ET in areas where the water table is too deep to be reached by vegetation. A rate of $12.0 \mathrm{in} / \mathrm{yr}$, similar to the ET rate measured in Ruby Valley, was applied to an area of about 184,000 acres to estimate annual ET from the alluvial slopes.

Total estimated ET on the valley floor in Ruby Valley in 2001 ranges from 330,000 to a maximum of about 420,000 acre-ft/yr and is comprised from five different land-cover types (table 7) on the basis of a July 16, 2001, satellite image. These types include areas of natural phreatophytic and nonphreatophytic vegetation, areas of open water and associated wet- 
Table 7. Estimated annual water budget for the Ruby Valley Hydrographic Area, northeastern Nevada

[The U.S. Geological Survey and Nevada Division of Water Resources delineated formal hydrographic areas in Nevada systematically in the late 1960's for scientific and administrative purposes (Cardinalli and other, 1968; Rush, 1968). The official hydrographic-area names, numbers, and geographic boundaries continue to be used in Geological Survey scientific reports and division of Water Resources administrative activities. Hydrographic-area boundaries generally coincide with drainage-area boundaries]

\begin{tabular}{|c|c|c|}
\hline \multirow{2}{*}{ Budget component } & \multicolumn{2}{|c|}{ Estimated flow, in acre-feet } \\
\hline & Minimum & Maximum \\
\hline \multicolumn{3}{|c|}{ Inflow (rounded) } \\
\hline Precipitation & $700,000^{1}$ & $910,000^{2}$ \\
\hline \multicolumn{3}{|l|}{ Subsurface inflow } \\
\hline Huntington Valley ${ }^{3}$ & 9,000 & 15,000 \\
\hline Northern Butte Valley ${ }^{4}$ & 800 & 800 \\
\hline 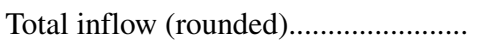 & 710,000 & 930,000 \\
\hline
\end{tabular}

\begin{tabular}{|c|c|c|}
\hline \multicolumn{3}{|l|}{ Evapotranspiration } \\
\hline Mountain block 5 & 270,000 & 270,000 \\
\hline Alluvial slope ${ }^{6}$ & 180,000 & 180,000 \\
\hline \multicolumn{3}{|l|}{ Valley floor ${ }^{7}$} \\
\hline Phreatophytic vegetation 6 & 170,000 & 170,000 \\
\hline Nonphreatophytic vegetation ${ }^{8}$ & 100,000 & 130,000 \\
\hline Open water and wetlands ${ }^{6}$ & 46,000 & 95,000 \\
\hline Wet playas ${ }^{9}$ & 1,500 & 5,000 \\
\hline Irrigated land ${ }^{10}$ & 11,000 & 16,000 \\
\hline Valley floor subtotal (rounded).... & 330,000 & 420,000 \\
\hline \multicolumn{3}{|l|}{ Subsurface outflow } \\
\hline Long Valley ${ }^{11}$ & 2,000 & 2,000 \\
\hline Clover Valley ${ }^{12}$ & 1,000 & 4,400 \\
\hline Total outflow (rounded)... & 780,000 & 870,000 \\
\hline \multicolumn{3}{|c|}{${ }^{1}$ Calculated from table 3 of Eakin and Maxey $(1951$, p. 80$)$} \\
\hline \multicolumn{3}{|c|}{${ }^{2}$ Altitude-location relation, equation 1 this report. } \\
\hline \multicolumn{3}{|l|}{${ }^{3}$ Dudley (1967). } \\
\hline \multicolumn{3}{|l|}{${ }^{4}$ Glancy (1968). } \\
\hline \multicolumn{3}{|l|}{${ }^{5}$ Mass-balance approach, this report. } \\
\hline \multicolumn{3}{|c|}{${ }^{6}$ Evapotranspiration rates from Berger and others (2001). } \\
\hline \multicolumn{3}{|c|}{$\begin{array}{l}{ }^{7} \text { Areal distributions of land-cover types used to estimate } \\
\text { evapotranspiration on valley floor are based on satellite imagery } \\
\text { obtained on July 16, } 2001 \text {. }\end{array}$} \\
\hline \multicolumn{3}{|c|}{${ }^{8}$ Evapotranspiration rates from Berger (2000a). } \\
\hline \multicolumn{3}{|c|}{${ }^{9}$ Evapotranspiration rates from Nichols (2000). } \\
\hline \multicolumn{3}{|c|}{$\begin{array}{l}{ }^{10} \text { Evapotranspiration rates from Harrill (1968), Prudic and Herman } \\
\text { (1996), Berger and others (1997), Plume (2003), and Maurer and others (in } \\
\text { press). }\end{array}$} \\
\hline \multicolumn{3}{|l|}{${ }^{11}$ Prudic and others (1995). } \\
\hline $\mathrm{n} 2$ th & & \\
\hline
\end{tabular}

lands, wet playas, and areas of irrigated land. Each land-cover type covers different areas on the valley floor and has different annual ET rates.

Based on the July satellite image, about 108,000 acres of the valley floor include phreatophytic vegetation where the depth to ground water generally is less than about $35 \mathrm{ft}$ below land surface. The source of water for ET in these areas is soil moisture derived mostly from precipitation and shallow ground water. Annual ET rates for phreatophytic vegetation in Ruby Valley have been determined from an energy-budget calculation based on micrometeorological data collected from May 1999 to October 2000 (Berger and others, 2001). The ET estimates were made in areas of sparse to moderate cover of mixed phreatophytes where the depth to ground water ranges from less than $5 \mathrm{ft}$ to nearly $200 \mathrm{ft}$ below land surface (sites 1 and 3-6; fig. 1). The average ET rate for the five sites is about $19.0 \mathrm{in} / \mathrm{yr}$ and is used to estimate about 170,000 acre-ft/yr of ET in areas of phreatophytic vegetation. For comparison, other ET estimates based on an energy-budget calculation range from 7.0 to $17.0 \mathrm{in} / \mathrm{yr}$ in areas of sparse to moderately dense shrub land in southern Nevada, where the water table ranges from 5 to about $20 \mathrm{ft}$ below land surface (Reiner and others, 2002, p. 30).

Nonphreatophytic vegetation on the valley floor covers about 133,000 acres, where the depth to ground water generally is greater than about $35 \mathrm{ft}$ below land surface and the source of water for ET principally is soil moisture derived from precipitation. Estimates of ET for nonphreatophytic vegetation on valley floors in Nevada are scarce. For purposes of developing the water budget for Ruby Valley, ET rates similar to those applied on the alluvial slopes in north-central Nevada (9 to 12 in/yr; Berger, 2000a; 2000b) where annual precipitation is less, were used. ET in areas of nonphreatophytic vegetation on the valley floor of the study area is estimated to range from 100,000 to 130,000 acre-ft/yr (table 7).

In Ruby Valley, the ET rate for open-water bodies was about $64 \mathrm{in} / \mathrm{yr}$ and for bulrush marsh was about $50 \mathrm{in} / \mathrm{yr}$ (Berger and others, 2001, p. 16). In 2001, about 9,900 acres were covered by open water and marsh vegetation in the Ruby Lake area. About 41 percent (4,050 acres) of the total area is open water and the remainder $(5,830$ acres) is covered by marsh vegetation. ET rates estimated by Berger and others (2001, p. 16) were applied for these area types that resulted in a total ET rate of about 46,000 acre-ft/yr (table 7). Franklin Lake had no areas of open water and consisted mostly of wet playa in 2001. In 1985, an estimated 8,500 acres of valley floor were covered by open water and about 12,000 acres were covered by marsh vegetation. Applying similar rates results in total ET of about 95,000 acre-ft in 1985 and may represent a maximum ET from these land-cover types.

As open-water bodies and wetlands associated with Ruby and Franklin Lakes recede, due to below average precipitation and evaporation, wet playas are created. ET take place through bare-soil evaporation in these wet playa areas. In Ruby Valley, wet playas covered about 9,800 acres in 2001 and about 33,000 acres in 1985. Depth to ground water beneath these wet 
playas typically is less than $1 \mathrm{ft}$ and the soils characteristically are saturated. Using an estimated ET rate of $1.8 \mathrm{in} / \mathrm{yr}$ for playas in Ruby Valley reported by Nichols (2000, p. C44) results in a minimum of about 1,500 to a maximum of about 5,000 acre-ft of ET in 2001.

The amount of irrigation water that is applied and subsequently consumed by ET depends, in part, on the application method. In 2001, about 2,000 acres of alfalfa were irrigated in Ruby Valley using the center-pivot sprinkler method. The center-pivot sprinkler method uses ground water from a well in the center of a circular field. The sprinkler system revolves in a circle of about 1/4-mile radius from the center-pivot well. Water-application rates by center-pivot sprinkler systems to irrigate alfalfa fields in central Nevada typically range from 2.5 to 3.0 acre-ft/acre per year (30 to 36 in/yr; Prudic and Herman, 1996, p. F. 28; Plume, 2003, p. 11). Using this range in application rate, an estimated 5,000 to $6,000 \mathrm{acre}-\mathrm{ft} / \mathrm{yr}$ of water is used to irrigate the 2,000 acres in Ruby Valley. Harrill (1968, p. 47) reported that about 75 percent of the total amount of water pumped for center-pivot sprinklers is consumed by ET or lost by spray and surface evaporation in Diamond Valley, about 15 mi southwest of Ruby Valley. Applying a similar consumption rate in Ruby Valley, results in an ET estimate for center-pivot irrigation from 3,800 to 4,500 acre-ft/yr. The remaining 25 percent is assumed to infiltrate to the water table.

Surface water that issues from the Ruby Mountains and East Humboldt Range was used to flood irrigate about 3,700 acres in Ruby Valley in 2001. Application rates for alfalfa using the flood-irrigation method range from about 3.0 to 4.0 acre-ft/acre per year (36 to $48 \mathrm{in} / \mathrm{yr}$; Prudic and Herman, 1996, p. F. 28; Plume, 2003, p. 11). Using this range in application rate, an estimated 11,000 to 15,000 acre-ft/yr of water is used to flood irrigate the 3,700 acres in Ruby Valley. Micrometeorological data collected in Carson Valley indicates ET rates for flood irrigation range from 2.0 to about 3.0 acre$\mathrm{ft} /$ acre per year (24 to $36 \mathrm{in} / \mathrm{yr}$; Maurer and others, in press). Applying this range to the 3,700 acres in Ruby Valley results in 7,400 to 11,000 acre-ft/yr of ET in flood irrigated areas. Estimated total ET for irrigated land in Ruby Valley ranges from 11,000 to 16,000 acre-ft/yr (table 7).

\section{Ground Water}

Virtually all ground water in Ruby Valley is derived from three sources: precipitation that falls within the hydrographic area, infiltration of streamflow from the west side of the southern Ruby Mountains, and subsurface inflow from Northern Butte Valley. Ground-water outflow takes place northeastward toward Clover Valley and possibly southeastward toward Long Valley. Most of the readily available ground water in the area of study occurs in basin-fill deposits under both unconfined (water table) and confined conditions.

\section{Sources and Movement}

The depth to ground water in basin-fill deposits in Ruby Valley during the spring of 2003 ranged from less than $5 \mathrm{ft}$ along the margins of Ruby Lake to more than $200 \mathrm{ft}$ beneath the alluvial slope in the northeast part of the valley (fig. 9). Depth to ground water tends to increase eastward and away from major sources of inflow generated in the Ruby Mountains.

During a 4-year period, (2000-03) water levels generally declined over much of the study area (fig. 10). The greatest decline, about $7 \mathrm{ft}$, was measured at well site 61 in the extreme southern part of the valley. Seasonal fluctuations in water levels were observed at well sites near Franklin and Ruby Lakes in response to changes in the lake's stage (sites 43 and 51, respectively; figs. 9 and 10). Well sites near areas of irrigation exhibited relatively steeper declines (sites 13 and 29; figs. 9 and 10), probably due to increased ground-water pumpage in response to below average precipitation and runoff. Ground-water levels in the east-central part of the valley show little change (site 32; figs. 9 and 10).

The general configuration of the water table in Ruby Valley in the spring of 2003 is shown in figure 11. The water-level contours were constructed from water-level measurements collected mostly in May 2003; however, for well sites 12, 13, and 16 (fig. 9) data collected in the previous spring were used. During this study, well site 26 was not accessible to collect water-level data. Water-level data from Glancy (1968, p. 30) was used for well site 26 and is assumed to be a fairly good representation of depth to water for spring 2003 based on small differences (about $1 \mathrm{ft}$ ) in water levels at sites 27 and 31 for the same measurement periods (19682003). Because the characteristics of the basin-fill aquifer are for the most part unknown, the water-level contours were constructed assuming homogeneous aquifer properties using linear interpolation between water-level data points. Total drilled depth of most wells used to construct the contour map is $200 \mathrm{ft}$ or less, implying that the water-level data, for the most part, represent the water table.

In the southern part of the valley, ground-water flow generally is toward Ruby Lake from adjacent mountains and continues north from Ruby Lake toward Franklin Lake. The amount of ground water that moves toward Franklin Lake from the Ruby Lake basin can be estimated using a modified form of Darcy's Law (Heath, 1983, p. 26):

$$
Q=0.0084 T W d h / d l
$$

where

$Q$ is the quantity of ground-water flow, in acre-feet per year;

$T$ is the transmissivity, in squared feet per day;

$W$ is the effective width of the flow section, in feet; $d h / d l$ is the hydraulic gradient, in feet of water-level change per foot of horizontal distance; and

0.0084 is the factor to convert cubic feet per day into acre-feet per year. 


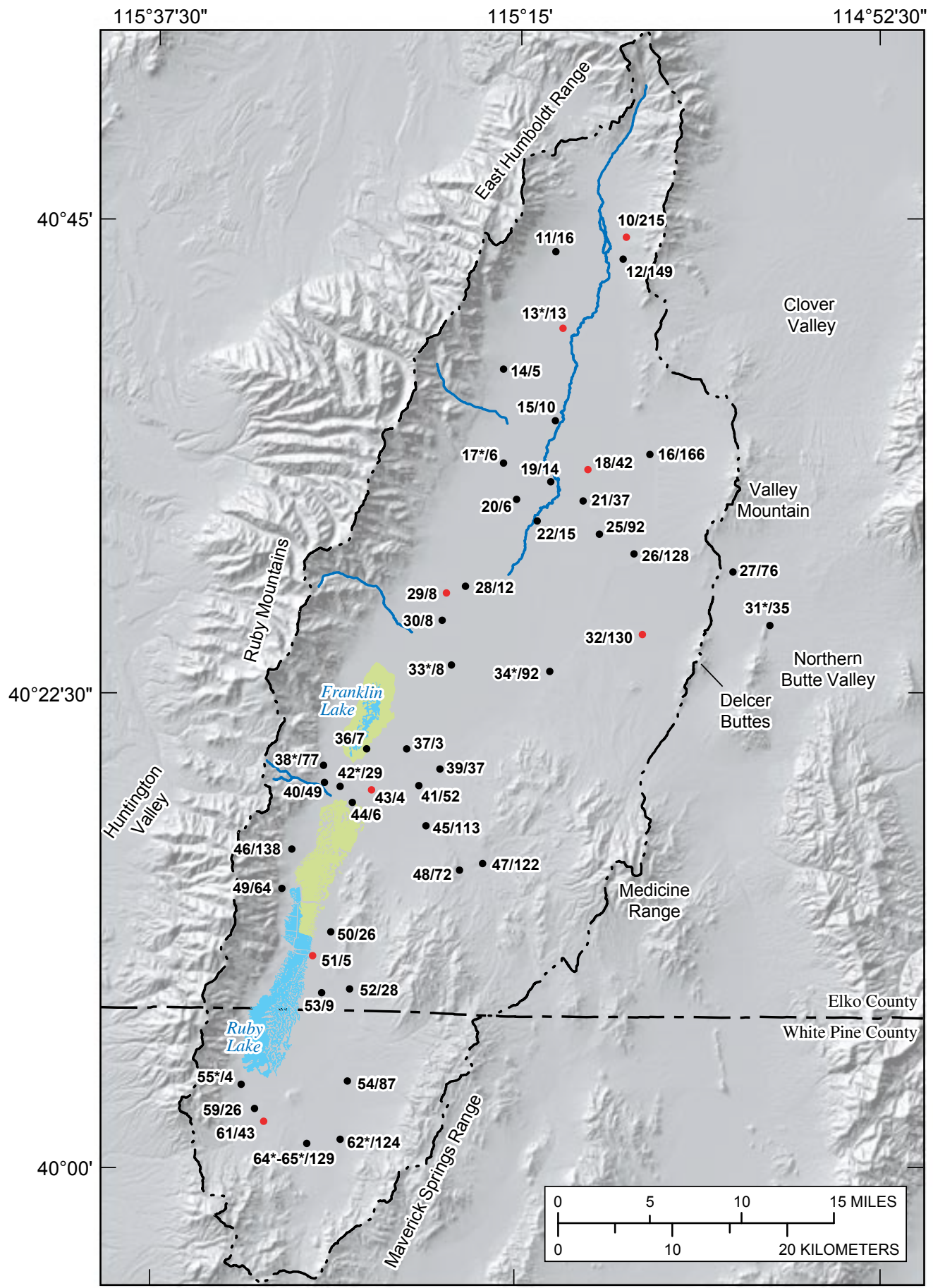

Base from U.S. Geological Survey digital data, 1:100,000,

1988. Universal Transverse Mercator projection, Zone 11.

Shaded-relief from 30-meter Digital Elevation Model; sun

illumination from northwest at 30 degrees above horizon.

\section{EXPLANATION}

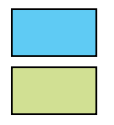

\section{Lake}

Wetland

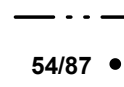

\section{Ruby Valley hydrographic-area boundary}

Well-First number is site number; second number is depth to water in feet below land surface. Site numbers listed in table 8 . Red symbol indicates hydrograph shown in figure 10; asterisk indicates water-quality data listed in table 8

Figure 9. Map showing site number and depth to ground water, for selected wells in spring 2003, in and near Ruby Valley, northeastern Nevada. 

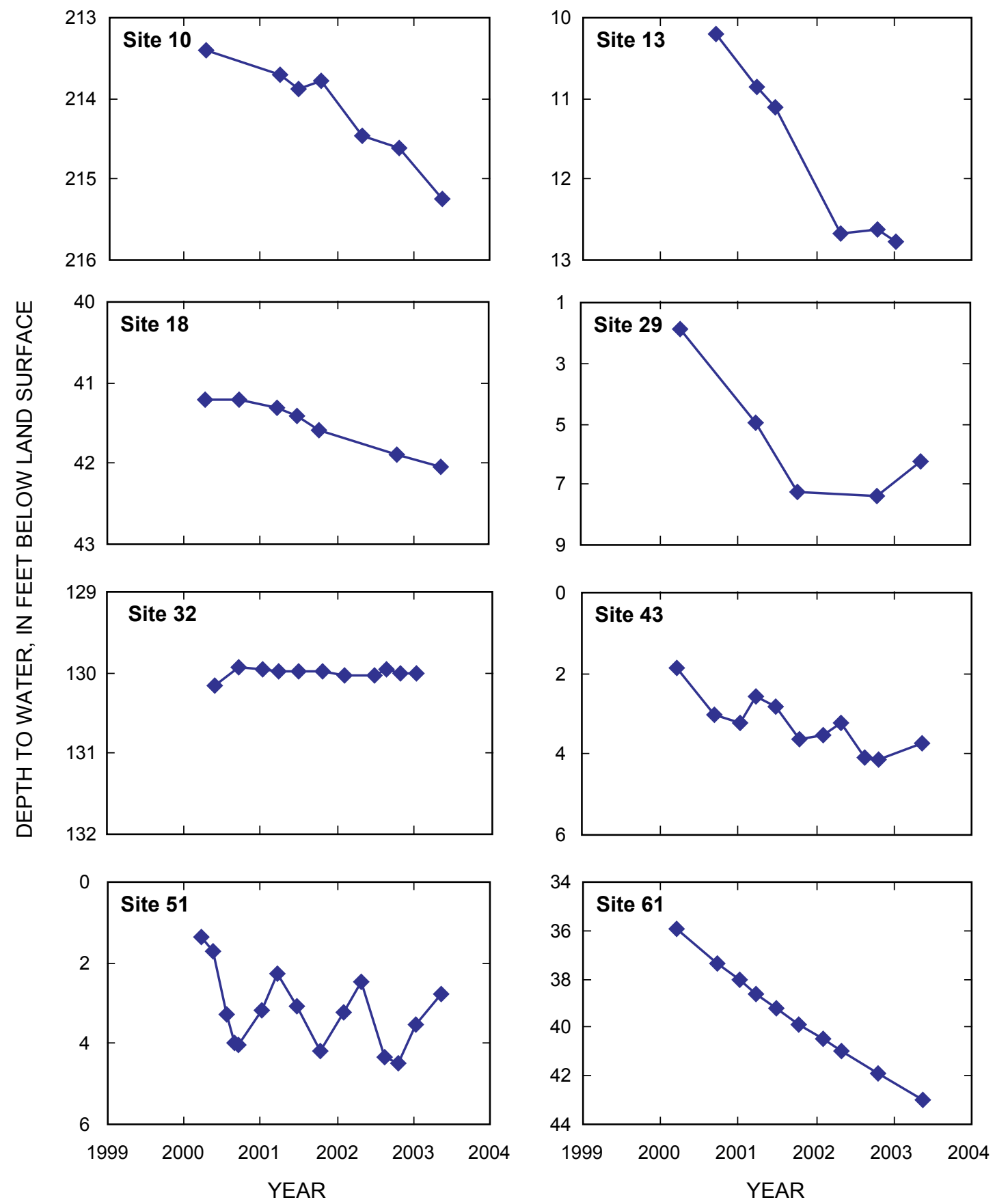

Figure 10. Hydrographs showing changes in water levels in selected wells in Ruby Valley, northeastern Nevada, 2000-03. See table 3 for site information. 


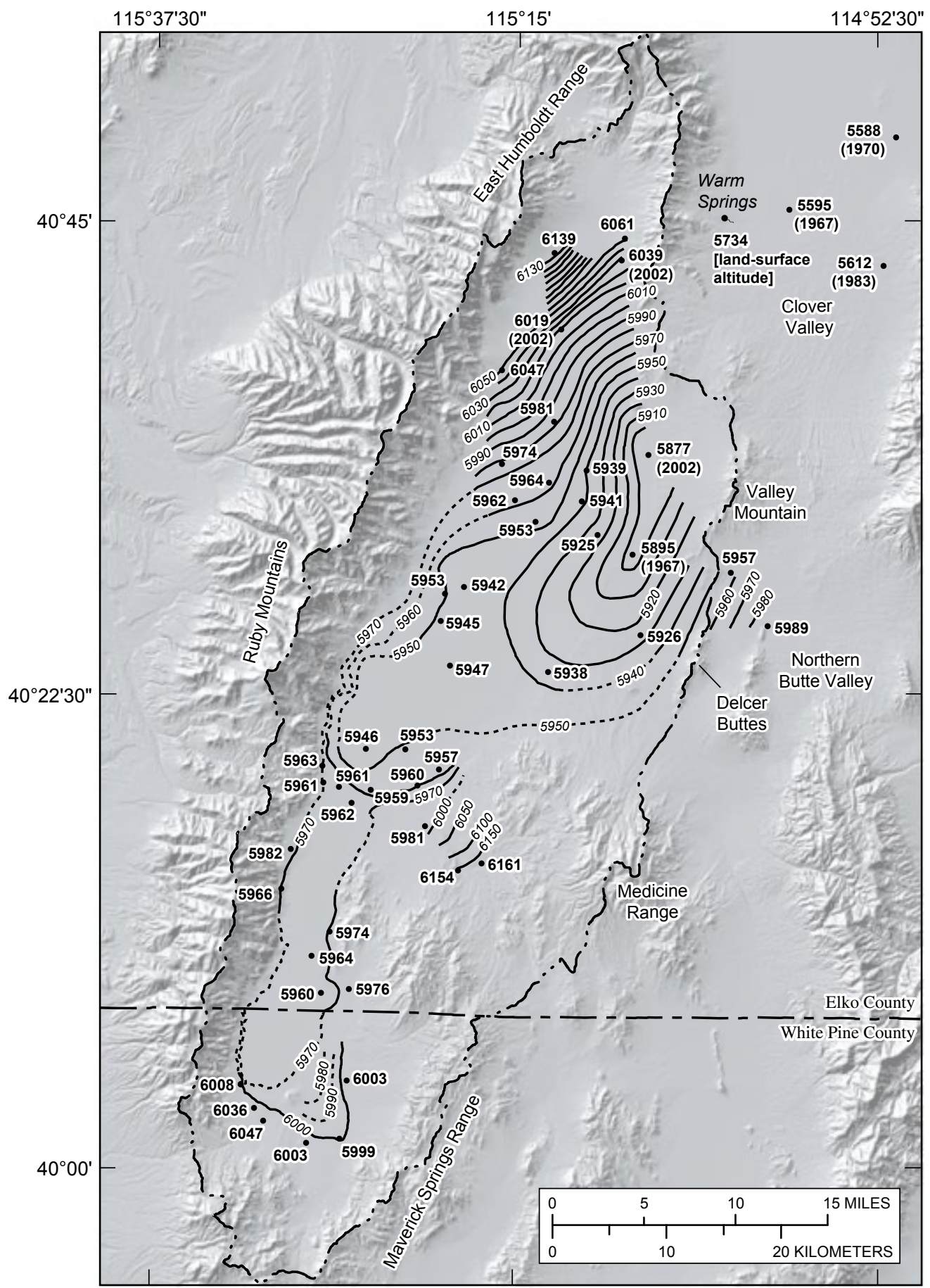

Base from U.S. Geological Survey digital data, 1:100,000,

1988. Universal Transverse Mercator projection, Zone 11.

Shaded-relief from 30-meter Digital Elevation Model; sun

illumination from northwest at 30 degrees above horizon.

\section{EXPLANATION}

- - - Ruby Valley hydrographic-area boundary

-5970---- Line of equal water-level altitude-

Interval in feet above sea level variable.

Dashed where uncertain
- 5595 Well with water-level altitude-In feet. (1967) Number in parentheses indicates year water level was measured

Figure 11. Map showing generalized ground-water levels in basin-fill deposits, spring 2003, in and near Ruby Valley, northeastern Nevada. 
A reasonable range of transmissivity for the basin-fill deposits between Ruby and Franklin Lakes is from 2,000 to 8,000 ft²/d (Glancy, 1968, p. 30; Harrill, 1968, p. 15; Prudic and others, 1995, p. D20). The effective flow width of the section is about $5 \mathrm{mi}(26,400 \mathrm{ft})$ and the hydraulic gradient is $5.3 \mathrm{ft} / \mathrm{mi}(0.001 \mathrm{ft} / \mathrm{ft})$. The estimated quantity of groundwater flow toward Franklin Lake from the south, based on equation 2, is from about 400 to 1,800 acre-ft/yr.

South of Ruby Lake, in the extreme southern part of the study area, well sites 64 and 65 (fig. 9) are housed in the same borehole and screened in basin-fill deposits (site 64) and carbonate rock (site 65). Water-level data from these wells indicate that there is a slight downward hydraulic gradient (less than $0.001 \mathrm{ft} / \mathrm{ft}$ ), indicating the potential for vertical flow of ground water from the basin-fill deposits to the underlying carbonate rock in that part of the study area during the measurement period (July 2002-August 2003). An unknown amount of ground water may flow through the carbonate rocks and out of the Ruby Valley HA to the south. Results of flow-model simulations indicate that about 2,000 acre-ft/yr of ground water flows south toward Long Valley along deep flow paths from Ruby Valley (Prudic and others, 1995, p. D80).

Rush and Everett (1966, p. 15) estimate about 10,000 acre-ft/yr of streamflow infiltration flows from Huntington Valley (HA 47) to Ruby Valley through solution openings in the carbonate rocks of the southern Ruby Mountains. Their estimate was based on lower than anticipated streamflow in Huntington Valley when compared to watershed drainage area and altitude. The movement of water from the west side of the southern Ruby Mountains to Ruby Valley is enhanced by the stratigraphic position and eastward dip of the carbonate rocks (Sharp, 1942, p. 685; Berger and others, 2001, p. 6). Dudley (1967, p. 77) states that, in addition, sinkholes and cirque lakes that form in the carbonate rocks are a source of persistent infiltration to the ground-water system in Ruby Valley. Based on synthesis of field evidence and results of an electric analog model, Dudley (1967, p. 98) estimated interbasin flow from Huntington Valley to Ruby Valley may range from 9,000 to 15,000 acre-ft/yr, which brackets the estimate of Rush and Everett (1966, p. 15). Much of this inflow is assumed to discharge at springs that lie along the western side of Ruby Lake and presumably beneath the lake.

The greatest concentration of perennial springs in the study area lie along the west side of Ruby Lake in the southern part of Ruby Valley (fig. 1). A spring inventory made in 1994 of 47 springs within the Ruby Lake NWR estimated nearly 75,000 acre-ft of ground-water discharge (Michael L. Richey, U.S. Fish and Wildlife Service, written commun., 1994). The 1994 estimate of spring discharge may represent a minimum because precipitation in the Ruby Mountains generally was below average during the 9 -year period preceding the spring inventory in 1994 (fig. 2). Cave Spring (site 69; fig. 1), which accounts for more than half of the total spring discharge within the Ruby Lake NWR, issues directly from the carbonate rocks and flows to Ruby Lake. The sulfur hexafluoride age-dating method (Busenberg and Plummer, 2000) was used to date the discharge from Cave Spring. The age-dating results indicate that recharge water in the southern Ruby Mountains takes about 5 to 7 years to discharge at Cave Spring. Similar travel times are assumed for other perennial springs in the area.

In the east-central part of the valley, water-level contour data indicate that ground water enters Ruby Valley from Northern Butte Valley (HA 178A) beneath an alluvial divide between Valley Mountain and Delcer Buttes (fig. 11). Glancy (1968, p. 30), applying Darcy's Law, estimated about 800 acre-ft/yr of ground-water inflow beneath this divide through basin-fill deposits from Northern Butte Valley. Glancy (1968, p. 30) used a hydraulic gradient across the divide of $7 \mathrm{ft} / \mathrm{mi}$ $(0.0013 \mathrm{ft} / \mathrm{ft})$, a transmissivity of about $6,700 \mathrm{ft}^{2} / \mathrm{d}$, and an effective flow width of about 2 mi.

Water-level data indicate that ground water moves from Ruby Valley, northeastward toward Clover Valley (fig. 11; HA 177), beneath an alluvial divide north of Valley Mountain. Based on available spring and ground-water-level data in Clover Valley, the hydraulic gradient across the divide ranges between 12 and $14 \mathrm{ft} / \mathrm{mi}(0.0023-0.0027 \mathrm{ft} / \mathrm{ft})$. Applying Darcy's Law (eq. 2) and assuming an effective flow width of the basin-fill deposits between consolidated rocks of about $4.5 \mathrm{mi}(24,000 \mathrm{ft})$ and a range in transmissivity of 2,000 to $8,000 \mathrm{ft}^{2} / \mathrm{d}$, ground-water outflow to Clover Valley is estimated to range from about 1,000 to $4,400 \mathrm{acre}-\mathrm{ft} / \mathrm{yr}$ through basin-fill deposits. This estimate may be a minimum if the carbonate rocks that make up the southern extension of the East Humboldt Range are permeable. Average discharge from Warm Springs, a regional spring along the eastern side of the southern extension of the East Humboldt Range in Clover Valley (fig. 11), is about 3,300 acre-ft/yr (Eakin and Maxey, 1951, p. 108). The land-surface altitude of Warm Springs (about 5,734 ft; fig. 11) and available ground-water levels, are more than $100 \mathrm{ft}$ lower than water levels in Ruby Valley. Prudic and others (1995, p. D33) simulated 5,000 acre-ft/yr of discharge from Warm Springs in a regional ground-water flow model of the carbonate-rock province.

\section{Recharge}

Precipitation is the principle source of ground-water recharge to Ruby Valley. Ground-water recharge from precipitation is unpredictable, particularly in arid and semiarid environments where precipitation is episodic and often of short duration. Previous estimates of ground-water recharge to Ruby Valley range from 68,000 acre-ft/yr (Eakin and Maxey, 1951 , p. 80) to 146,000 acre-ft/yr (Nichols, 2000, p. C54). Both estimates were derived as fixed fractions of precipitation and are a direct function of the particular precipitation data used in the recharge estimate. Basin-scale methods commonly are used to estimate recharge from precipitation in Nevada and generally are considered to be reconnaissance-level estimates.

The chloride-balance method is another basin-scale reconnaissance method for estimating ground-water recharge that is, in part, a function of precipitation (Claassen and others, 1989; Dettinger, 1989). Because the concentration of 
chloride dissolved in ground water generally is not affected by adsorption or ion exchange, it can be used as a natural tracer for estimating ground-water recharge from precipitation, assuming that all sources of chloride are known. This method is based on the balance between total chloride concentration in bulk precipitation (dry and wet) that falls in recharge-source areas (typically mountain-block areas and upper parts of alluvial slopes) and chloride concentration in ground water in and near recharge areas. The annual volume of groundwater recharge based on the chloride-balance method can be approximated as follows:

where

$$
R=P\left(C l_{p} / C l\right)
$$

$R$ is recharge, in acre-feet per year,

$P$ is total precipitation that falls in recharge-source areas, in acre-feet per year,

$\mathrm{Cl}_{p}$ is chloride concentration in bulk precipitation, in milligrams per liter, and

$\mathrm{Cl}_{r}$ is chloride concentration in ground water from recharge areas, in milligrams per liter.

About 420,000 acre-ft/yr of precipitation $(P)$ falls on mountain-block areas and about 230,000 acre-ft/yr falls on the alluvial slopes in Ruby Valley and are assumed, in this study, to represent principal recharge-source areas. Chloride concentration in precipitation $\left(\mathrm{Cl}_{p}\right)$ is reported to be about 0.4 $\mathrm{mg} / \mathrm{L}$ for much of the Great Basin (Dettinger, 1989, p. 62; Berger and others, 1997, p. 46). Concentration of chloride in ground water from recharge areas $\left(\mathrm{Cl}_{r}\right)$ is assumed to be represented by the average concentration in samples from sites $38,42,55,69,70,71$, and 76 and is about $2.6 \mathrm{mg} / \mathrm{L}$ (table 8; figs. 1 and 9). Substituting these values into equation 3 results in an estimate of about 100,000 acre-ft/yr.

Additional ground-water recharge takes place from applied irrigation water. Applied irrigation water not consumed by ET is assumed to recharge the shallow groundwater system. About 4,800 to 5,500 acre-ft/yr were estimated to become recharge beneath irrigated lands in Ruby Valley in 2001. Average ground-water recharge to the Ruby Valley ground-water flow system is about 105,000 acre-ft/yr.

\section{Water Quality}

Water samples were collected from 16 wells and 11 springs in and near Ruby Valley (table 8; figs. 1 and 9) and analyzed for major-ion and nutrient concentrations and stableisotopic composition. Field parameters (dissolved oxygen, $\mathrm{pH}$, specific conductance, and water temperature) were measured on site. Concentrations of selected constituents measured in the ground water are compared to primary and secondary drinking-water standards (U.S. Environmental Protection Agency, 2005). Primary standards are an enforceable, maximum concentration allowed in public water supplies; secondary standards are not enforceable and are based on aesthetic properties of constituents, not health related effects. No primary drinking-water standards were exceeded for any of the constituents that were analyzed. Several secondary standards were exceeded at three wells (sites 17, 31, and 33; table 8; fig. 9). Samples from sites 17 and 33 were 1.98 $\mathrm{mg} / \mathrm{L}$ and $2.04 \mathrm{mg} / \mathrm{L}$ for fluoride, respectively, very near the secondary standard of $2 \mathrm{mg} / \mathrm{L}$, and site 17 was $57.2 \mu \mathrm{g} / \mathrm{L}$ for manganese, which exceeded the secondary standard of 50 $\mu \mathrm{g} / \mathrm{L}$. Site 31 exceeded the secondary standard of $300 \mu \mathrm{g} / \mathrm{L}$ for iron at 2,620 $\mu \mathrm{g} / \mathrm{L}$ and manganese at $80 \mu \mathrm{g} / \mathrm{L}$. Secondary standards for sulfate $(250 \mathrm{mg} / \mathrm{L})$ and dissolved solids $(500$ $\mathrm{mg} / \mathrm{L}$ ) also were exceeded in samples from site 31 at 300 $\mathrm{mg} / \mathrm{L}$ and $883 \mathrm{mg} / \mathrm{L}$, respectively (table 8 ). Site 33 was outside the range of the secondary standard for $\mathrm{pH}$ of 6.5 to 8.5 at 8.9 and exceeded the standard for dissolved solids at $1,330 \mathrm{mg} / \mathrm{L}$.

Trilinear (Piper) diagrams (fig. 12) show the chemical character of water in terms of milliequivalents-per-liter percentages of major dissolved constituents (Hem, 1985). Most ground water sampled in the area of study is a calciumbicarbonate type water (fig. 12). The sample from well site 31, in Northern Butte Valley, is a sodium-sulfate type water with dissolved-solids concentration of $883 \mathrm{mg} / \mathrm{L}$. The sample from well site 33, near the center of Ruby Valley, is a sodiumbicarbonate type water with dissolved-solids concentration of $1,330 \mathrm{mg} / \mathrm{L}$. Dissolved-solids concentration for the remaining sites range from 177 to $346 \mathrm{mg} / \mathrm{L}$ (table 8).

The elevated dissolved-solids concentration in groundwater samples from sites 31 and 33 (fig. 1) is a result of either ET or dissolution of evaporative salts. The relation between the stable hydrogen isotope of water (delta deuterium) and chloride concentration has been used to indicate the processes concentrating ions in ground water (Welch and Preissler, 1990, p. 31; Berger, 1995, p. 32). On the basis of a plot of delta deuterium as a function of chloride concentration, the increase in dissolved solids in the ground water appears to be related to transpiration or the dissolution of evaporative salts, or both, rather than direct evaporation (fig. 13). Transpiration and salt dissolution increase ion concentrations in solution without appreciably changing the delta-deuterium composition. Water sampled from the Ruby Lake NWR (sites 2 and 7; fig. 13) have much more positive delta-deuterium values than most ground water in the study area indicating the lake water has been evaporated.

\section{Lakes}

Ruby and Franklin Lakes are terminal lakes that occupy the lowest areas in Ruby Valley (fig. 1). Ruby Lake is maintained primarily from perennial spring discharge with little surface-water inflow with only about 20 to 25 percent direct precipitation (Thompson, 1992, p. 2). Ruby Lake has maintained at least small open-water pools through nearly all of the historic droughts (Thompson, 1992, p. 2). In contrast, Franklin Lake was completely dry for 6 of the 26 years between 1960 and 1986 (Csuti, 1987) and is maintained 
Table 8. Results of chemical analyses for water samples from selected evapotranspiration, well, spring and surface-water sites, Ruby Valley, northeastern Nevada

[Abbreviations and symbols: $\mathrm{mg} / \mathrm{L}$, milligrams per liter; $\mu \mathrm{g} / \mathrm{L}$, micrograms per liter; $\mu \mathrm{S} / \mathrm{cm}$, microsiemens per centimeter at 25 degrees Celsius; ${ }^{\circ} \mathrm{C}$, degrees Celsius; per mil, parts per thousand; <, less than; E, estimated value; —, not determined. Deuterium and oxygen are relative to Vienna Standard Mean Ocean Water]

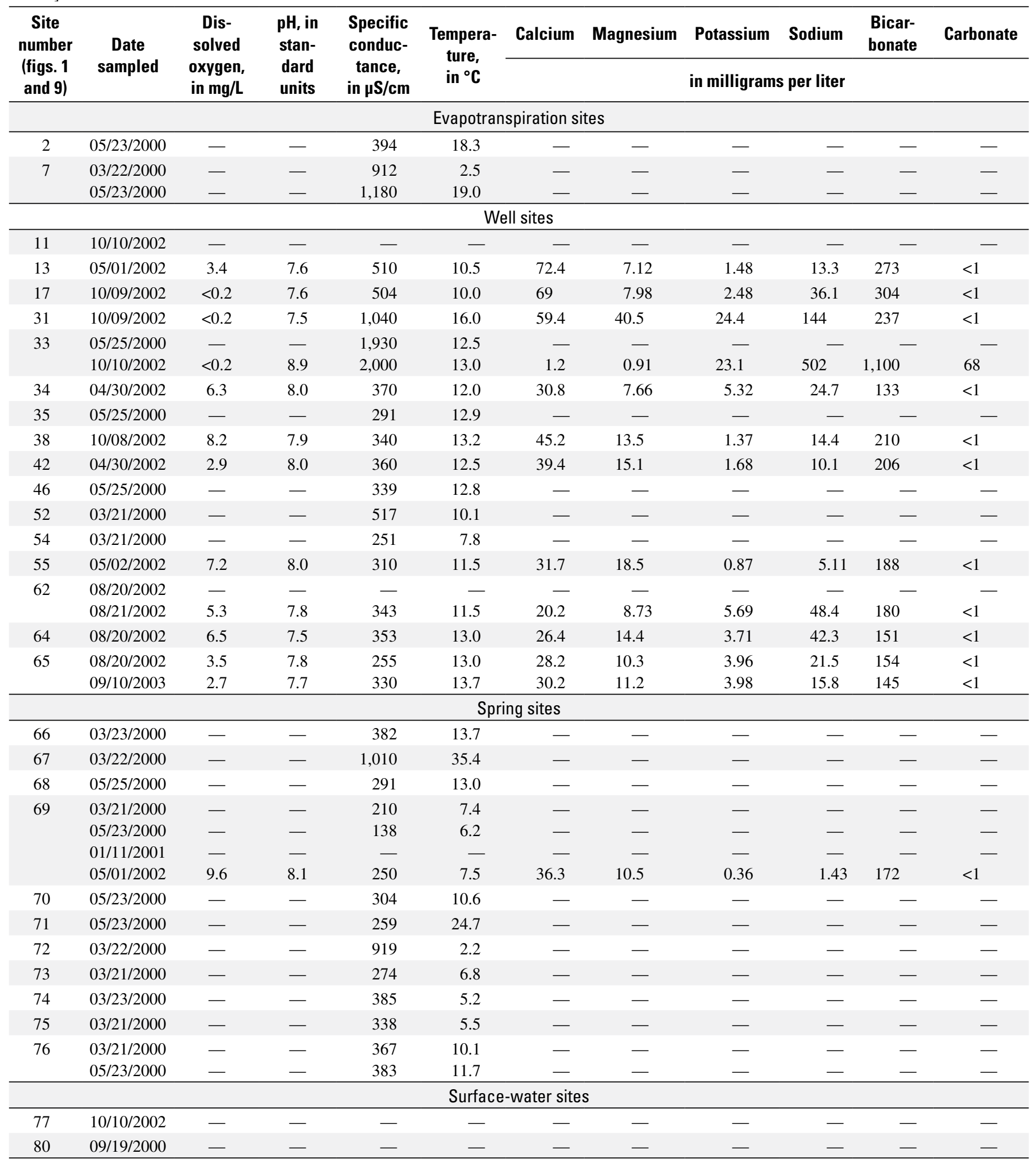


Table 8. Results of chemical analyses for water samples from selected evapotranspiration, well, spring and surface-water sites, Ruby Valley, northeastern Nevada-Continued

[Abbreviations and symbols: $\mathrm{mg} / \mathrm{L}$, milligrams per liter; $\mu \mathrm{g} / \mathrm{L}$, micrograms per liter; $\mu \mathrm{S} / \mathrm{cm}$, microsiemens per centimeter at 25 degrees Celsius; ${ }^{\circ} \mathrm{C}$, degrees Celsius; per mil, parts per thousand; <, less than; E, estimated value; - , not determined. Deuterium and oxygen are relative to Vienna Standard Mean Ocean Water]

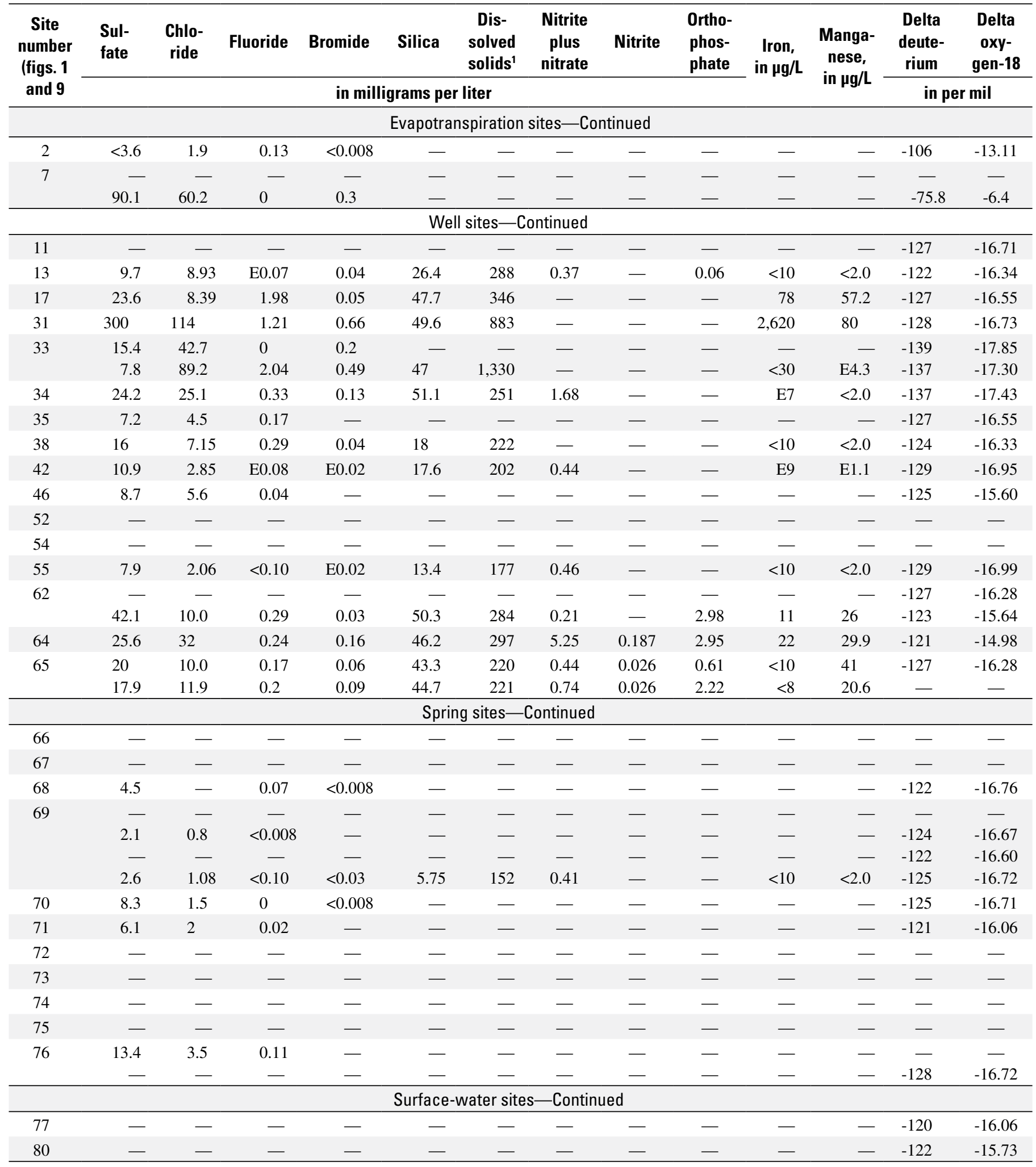

${ }^{1}$ Dissolved solids determined as residue on evaporation at $180^{\circ} \mathrm{C}$. 


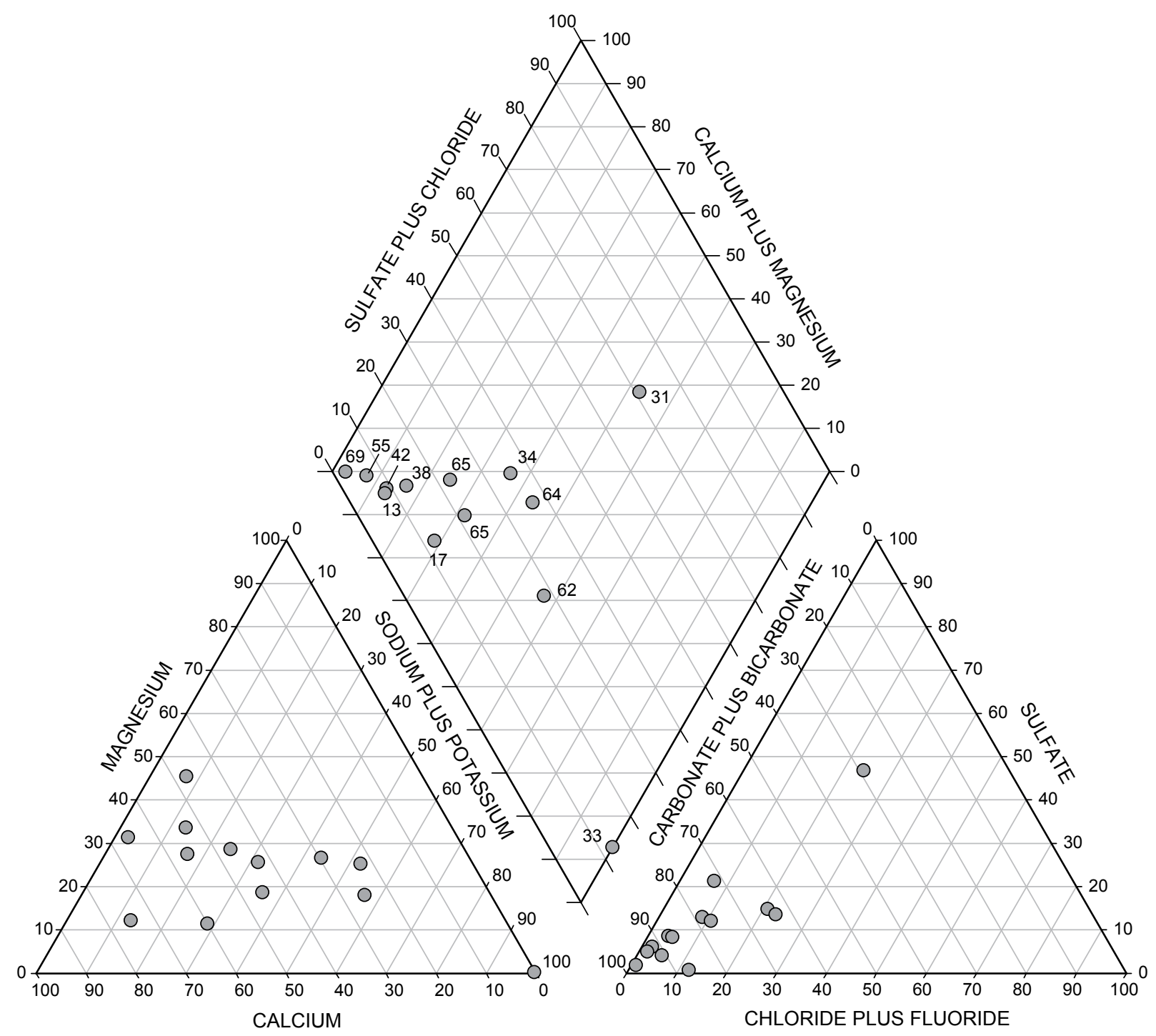

Figure 12. Graph showing major ion composition of ground water sampled in and near Ruby Valley, northeastern Nevada. See table 8 for site information.

ephemerally by direct precipitation, surface-water runoff, and irrigation return flow, and as a result fluctuates with seasonal precipitation and evaporation. Satellite imagery indicates that in June 1985, Franklin Lake had about 5,800 acres of open water and bulrush marsh, whereas Ruby Lake had about 15,000 acres. Although precipitation in 1985 generally was below average, the 3 years preceding 1985 were well above average (fig. 2). Conditions in 1985 may represent a near maximum extent of open water during the 30 -year period (1971-2000). In July 2001, Franklin Lake had no open water and Ruby Lake had declined to about 4,000 acres of open water and about 5,800 of wetland vegetation.

The proportion of the stable isotopes of oxygen-18 and deuterium in water molecules can be used to infer the source and evaporative history of the water. The relation of oxygen-18 to deuterium in water sampled for this study is shown in figure
14. Because a local meteoric water line has not been developed for the area of study, the mean global meteoric-water line developed by Craig (1961) is used to represent the isotopic composition of precipitation. During the process of evaporation, water becomes progressively enriched in oxygen-18 and deuterium (less negative values). This enrichment results in a deviation from the meteoric-water line along a trajectory with a lower slope (evaporation line). Samples collected from Ruby Lake NWR define an evaporation line that indicates the source of water to Ruby Lake principally is spring discharge, although precipitation may contribute a small amount (fig. 14; sites 2 and 7).

The generally low salinity of Ruby Lake initially was reported by Dudley (1962, p. 72) who stated that because there is no surface-water outlet, ground-water outflow from the lake basin must take place in order for the lake to remain 


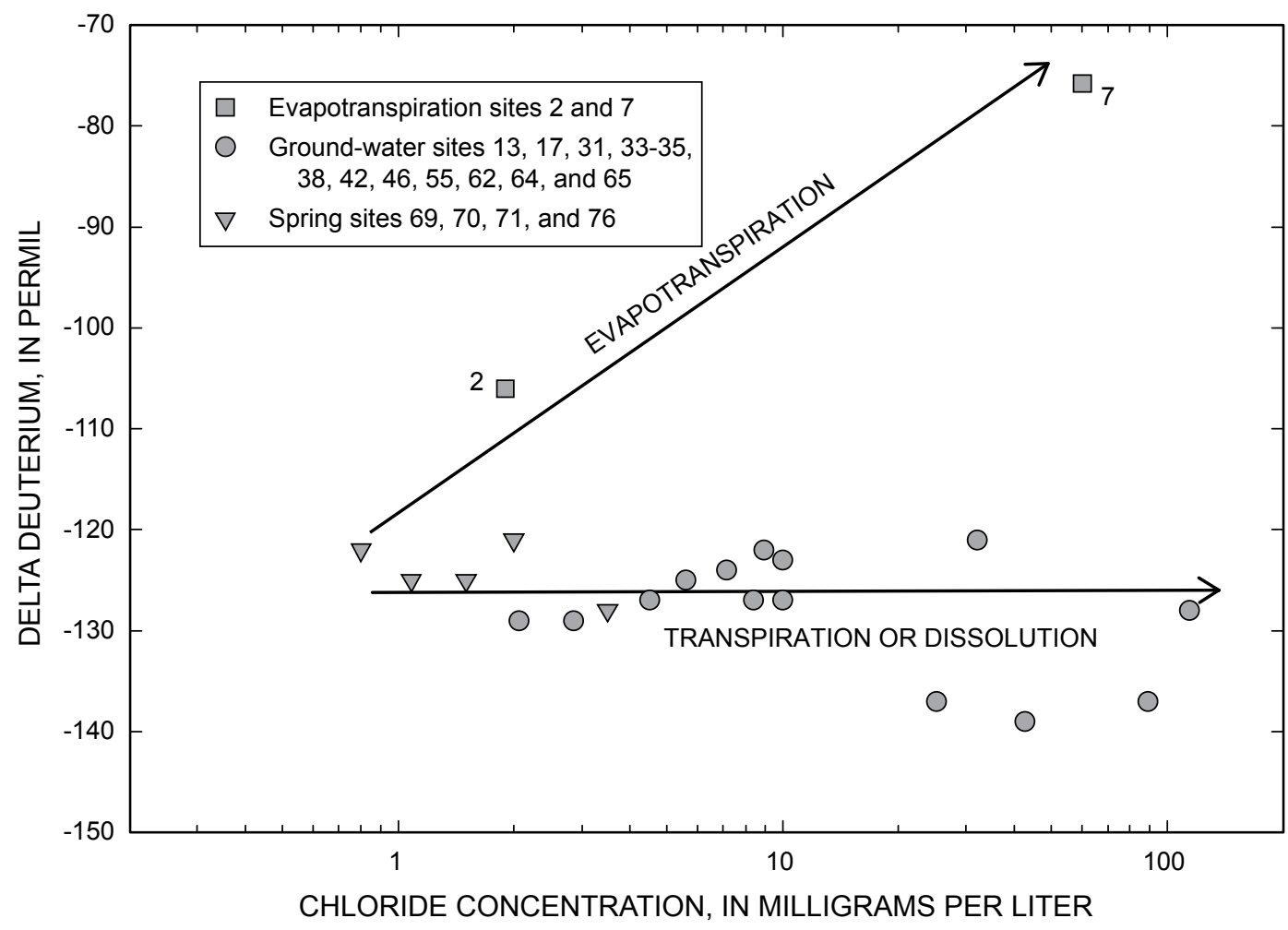

Figure 13. Graph showing relation between delta deuterium and logarithm of chloride concentrations in sampled water in and near Ruby Valley, northeastern Nevada. See figures 1 and 9 for site location.

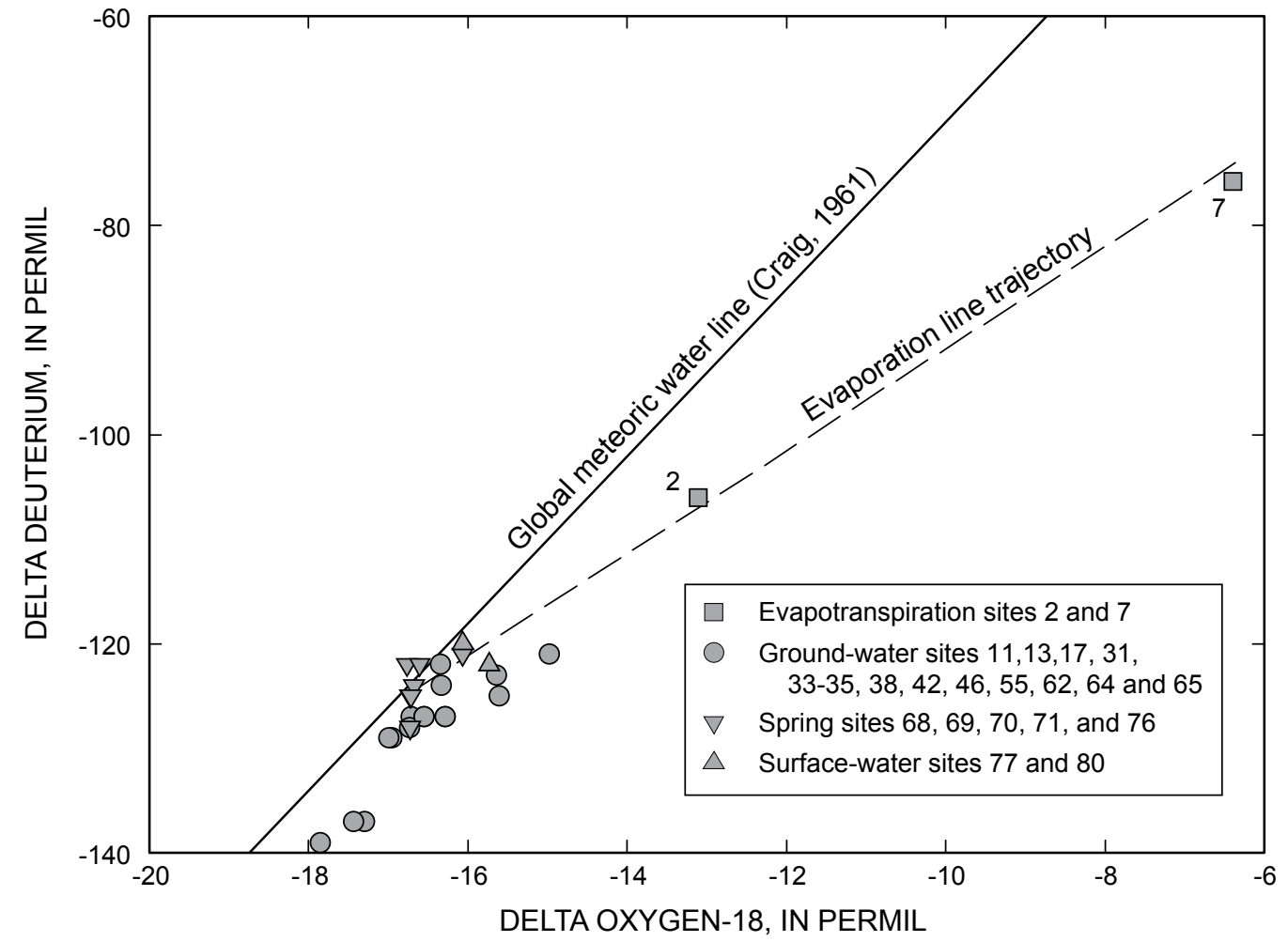

Figure 14. Graph showing relation of delta deuterium to delta oxygen-18 in sampled water from evapotranspiration, ground-water, spring, and surface-water sites in and near Ruby Valley, northeastern Nevada. 
fresh. Dudley (1967, p. 72) also stated ground-water inflow to the lake probably is significantly greater than ground-water outflow. A chloride-mass-balance calculation was used to better understand the mechanisms that maintain the freshwater quality of the lake. The chloride-mass-balance equation can be written as:

$$
C l_{p} Q_{p}+C l_{s p r} Q_{s p r}=C l_{e t} Q_{e t}+C l_{o w} Q_{o w}
$$

where

$\mathrm{Cl}_{p}, \mathrm{Cl}_{s p r}, \mathrm{Cl}_{e t}$, and $\mathrm{Cl}_{\text {ow }}$ are concentrations of chloride in precipitation, spring discharge, water vapor, and outflow water, respectively, in milligrams per liter; and

$Q_{p}, Q_{s p r}, Q_{e t}$, and $Q_{o w}$ are quantities of precipitation that falls directly on the lake, spring discharge to the lake, evapotranspiration from the lake, and ground-water outflow from the lake basin, respectively, in acre-feet per year.

Chloride concentration in precipitation $\left(\mathrm{Cl}_{p}\right)$ is reported to be about $0.4 \mathrm{mg} / \mathrm{L}$ for much of the Great Basin (Dettinger, 1989, p. 62; Berger and others, 1997, p. 46). Water samples from spring sites 69 and 70 (table 8), indicate chloride concentration in springs that discharge directly to the lake $\left(C l_{s p r}\right)$ is about $1.1 \mathrm{mg} / \mathrm{L}$. Chloride is not removed by ET processes, so $\mathrm{Cl}_{e t}$ is zero. Chloride concentration in Ruby Lake, representing outflow water $\left(\mathrm{Cl}_{\text {ow }}\right.$; site 7 ; table 8$)$ is 60.2 $\mathrm{mg} / \mathrm{L}$. The quantity of precipitation that falls directly on Ruby Lake $\left(Q_{p}\right)$ is about 8,000 acre-ft/yr (Berger and others, 2001, p. 25). Spring discharge to the lake $\left(Q_{s p r}\right)$ is estimated to be 75,000 acre-ft/yr (Michael L. Richey, U.S. Fish and Wildlife Service, written commun., 1994). Evapotranspiration from Ruby Lake $\left(Q_{e t}\right)$ and associated wetlands is about 50,000 acre$\mathrm{ft} / \mathrm{yr}$ (Berger and others, 2001, p. 24). However, because $\mathrm{Cl}_{e t}$ is zero, the value is not used in the calculation.

Solving equation 4 for ground-water outflow $\left(Q_{o w}\right)$ results in about 1,400 acre-ft/yr of ground-water outflow required to maintain the chloride balance and the freshwater quality of the lake. This estimate falls within the range of ground-water outflow derived using Darcy's Law of 400 to 1,800 acre-ft/yr. The low salinity in Ruby Lake appears to be maintained by the large contribution of freshwater from spring discharge and to a lesser extent by ground-water flow toward Franklin Lake. Using the previous values of inflow and outflow in a water budget for Ruby Lake results in an imbalance of about 32,000 acre-ft. Either the quantity of ET is underestimated, the inflow from spring discharge is overestimated, or some combination of the two accounts for the imbalance.

\section{Water Budget}

The hydrologic conditions used to develop the water budget for Ruby Valley are characterized by data collected as part of the overall study of Ruby Valley and other contemporary investigations. Estimates for many of the budget components presented in the following section have been derived from recently collected data, generally spanning from 1999 through 2003. For purposes of this analysis, the precipitation distribution determined from equation 1 , which is based on recent data (1971-2000), is used in the water budget for consistency. Determination of areal distributions of open-water bodies, wetlands, wet playas, phreatophytic and non-phreatophytic vegetation, and irrigated lands were developed from a satellite image obtained on July 16, 2001, and augmented by comparison with earlier satellite images and recent field mapping. Areas of open water and associated wetland vegetation and wet playas vary seasonally and annually, depending on the quantity of precipitation in proceeding years. Precipitation during 2001 generally was below the average for the period 1971-2000 (fig. 2). Estimates of inflow and outflow that make up the annual water budget for Ruby Valley are summarized in table 7.

\section{Inflow}

Total inflow to Ruby Valley ranges from about 710,000 to nearly 930,000 acre-ft/yr (table 7). Precipitation represents the largest inflow component and ranges from 700,000 acre-ft/yr, based on the Hardman (1936) precipitation map (Eakin and Maxey, 1951, p. 80), to 910,000 acre-ft/yr, derived from the relation between altitude and location (eq. 1). Precipitation in the mountain-block areas accounts for about 46 percent of the total precipitation. About equal amounts of precipitation fall on the alluvial slopes and valley floor annually. Estimates of subsurface inflow represent less than 2 percent of the total and range from about 10,000 to 16,000 acre-ft/yr (table 7; Rush and Everett, 1966, p. 15; Dudley, 1967, p. 98; Glancy, 1968, p. $30)$.

\section{Outflow}

Estimates of total outflow from Ruby Valley range from about 780,000 to 870,000 acre-ft/yr (table 7). Estimated total ET on the valley floor of Ruby Valley ranges from about 330,000 to 420,000 acre-ft/yr (table 7). Subsurface outflow northeast toward Clover Valley and south toward Long Valley totals about 3,000 to 6,400 acre-ft/yr and represents less than 1 percent of the total outflow from Ruby Valley (table 7). These estimates may represent minimum values because some ground water may move through carbonate rocks that is not accounted for in these estimates.

Although the estimated water budget is subject to a number of qualifications and uncertainties, the budget illustrates the relative distribution and movement of water. The range in values for several budget components also illustrates the uncertainty, some of which may be due to climatic variability, particularly precipitation and components of ET. Uncertainty in the water-budget components could be reduced by collection of additional climatic and hydrologic data. Additional 
precipitation data on the valley floor and in the mountains that border the eastern part of Ruby Valley would help in understanding the rain-shadow effect on the distribution of annual precipitation. A numerical ground-water flow model could be used with additional hydrologic data to refine estimates of subsurface inflow and outflow, particularly through carbonate rocks that border the area of study.

Annual precipitation estimated from the altitude-location relation (eq. 1) was derived using 30-year averages (19712000). In contrast, much of the ET components are based on 2001 hydrologic conditions. Although age-dating of spring discharge indicates a 5- to 7-year lag time between precipitation and discharge, the relation between annual precipitation and the distribution of ET is unknown. A more complete analysis of temporal satellite images may provide insight to the relation among annual precipitation, ET, and the areal extent of Ruby and Franklin Lakes and associated wetland areas.

\section{Summary and Conclusions}

Ruby Valley is a large, topographically closed basin in northeastern Nevada with an area of about 1,000 $\mathrm{mi}^{2}$ in Elko and White Pine Counties. The valley is relatively undeveloped and currently the subject of water-right adjudication proceedings. Although Ruby Valley is sparsely populated, steady rural development is taking place and expected to increase in the future. Because Ruby Valley is a "Designated Basin," the use of committed ground-water rights are limited to the basin's long-term recharge. The water resources of Ruby Valley were last evaluated in 1951 and since then additional hydrologic and climatic data have been collected, and new techniques and approaches have been developed for water-resources analysis.

The geologic history that has shaped Ruby Valley is complex and includes periods of regional metamorphism, thick accumulations of sedimentary and volcanic rocks, major tectonic events, glaciation, and cyclic fluctuations of a large closed-basin lake. The more than two dozen geologic units recognized in the study area are grouped into nine hydrogeologic units on the basis of lithology and hydrologic similarities. Cenozoic basin-fill deposits are grouped into two hydrogeologic units, valley-floor and alluvial-slope deposits. Valley-floor deposits cover about $370 \mathrm{mi}^{2}$ and consist mostly of unconsolidated gravel and sand that readily transmit water. Included in the valley-floor unit are deposits of lacustrine origin that generally have low permeabilities. Alluvial-slope deposits, which cover about $290 \mathrm{mi}^{2}$ and occupy the area between the valley floor and the mountain blocks, consists of several topographic parts, including dissected pediments and alluvial fans.

Consolidated rocks, which form the mountain blocks and underlie the deposits that fill the valley are grouped into seven hydrogeologic units. The carbonate unit covers nearly $170 \mathrm{mi}^{2}$ and makes up the entire southern Ruby Mountains and much of the Maverick Springs Range and Valley Mountain.
The existence of Ruby Lake and the associated wetland is due to the highly permeable nature and stratigraphic position of the carbonate unit. The water yield from the southern Ruby Mountains essentially has no streamflow component due to the enhanced permeability of the carbonate rocks, and as a consequence the eastward drainage is almost entirely made up of spring discharge. The hydrogeologic characteristics of the carbonate unit are in sharp contrast to the characteristics of the intrusive and metamorphic units that makes up the central and northern Ruby Mountains and much of the East Humboldt Range. Due to the relatively low permeability, streamflow makes up the largest component of the water yield from these areas. The tuffaceous rocks and sediments units probably underlie much of the valley floor. The remaining hydrogeologic units are of limited extent and consist of three units of Cenozoic volcanic rocks, and one clastic unit of Precambrian to Mesozoic age. The Cenozoic basin-fill deposits, and volcanic and sedimentary rocks that fill the structural basin beneath Ruby Valley range in thickness from less than $500 \mathrm{ft}$ along the margins to about $10,000 \mathrm{ft}$ beneath the south-central part of the valley.

The amount of precipitation in Ruby Valley, derived from four estimates, ranges from about 700,000 acre-ft/yr developed from the Hardman precipitation map of Nevada to 910,000 acre-ft/yr based on a relation that incorporates station altitude and location. The Hardman precipitation map shows about 25 to 31 percent less annual precipitation than the other estimates. Most of the differences in the total precipitation are related, in part, to differences in climatic conditions during the period of estimated precipitation. The Hardman precipitation map was developed prior to 1935 when severe drought conditions were occurring in northeastern Nevada. The other estimates, however, were developed based on data from 1961-90 and 1971-2000, when the climatic conditions were somewhat wetter.

Total runoff to Ruby Valley, based on a range in unit-area runoff from 740 to $950 \mathrm{acre}-\mathrm{ft} / \mathrm{mi}^{2}$ per year, is about 82,000 to 100,000 acre-ft/yr. Runoff that issues from the east side of the Ruby Mountains north of Harrison Pass Creek and from the southwest flank of the East Humboldt Range, under natural conditions, terminates in Franklin Lake. Streams south of and including Harrison Pass Creek and those issuing from the Maverick Springs Range terminate in Ruby Lake. The northern Ruby Mountains and East Humboldt Range generate about 80 percent of the total runoff to Ruby Valley.

Virtually all ground water in Ruby Valley is derived from three sources: precipitation that falls within the hydrographic area, infiltration of streamflow from the west side of the southern Ruby Mountains, and subsurface inflow from Northern Butte Valley. Ground-water outflow takes place northeastward toward Clover Valley and possibly southward toward Long Valley. Most of the readily available ground water in the area of study occurs in basin-fill deposits under unconfined and confined conditions. The depth to ground water in basin-fill deposits in Ruby Valley during the spring of 2003 ranges from less than $5 \mathrm{ft}$ along the margins of Ruby Lake to more than 20 
$\mathrm{ft}$ beneath the alluvial slope in the northeast part of the valley. During the 4-year period (2000-03) water levels generally declined over much of the study area.

Previous estimates of ground-water recharge from precipitation range from 68,000 to 146,000 acre-ft/yr. Results of applying the chloride-balance method indicate average ground-water recharge is about 100,000 acre-ft/yr. These basin-scale estimates are considered reconnaissance-level estimates and generally are a function of the particular precipitation data used in the recharge estimate.

Water samples were collected from 16 wells and 11 springs in and near Ruby Valley and analyzed for major-ion and nutrient chemistry and stable-isotopic composition. No primary drinking-water standards were exceeded for any of the constituents that were analyzed. Secondary drinkingwater standards were exceeded for manganese, sulfate, iron, dissolved solids, and $\mathrm{pH}$ at three wells. Most of the water sampled in the area of study is a calcium-bicarbonate type.

Although Ruby Lake is a terminal lake and has no surface-water outlet, the lake water generally is fresh. Based on a chloride-mass-balance calculation, the low salinity in Ruby Lake is maintained by a large contribution of freshwater from spring discharge and to a lesser extent by ground-water flow toward Franklin Lake. Ruby Lake has maintained at least small open-water pools through nearly all of the historic droughts. In contrast, Franklin Lake was completely dry for 6 of the 26 years between 1960 and 1986. Ruby Lake receives perennial spring discharge, whereas Franklin Lake is maintained ephemerally by direct precipitation, surface-water runoff, and irrigation return flow. Based on satellite imagery, in June 1985 an estimated 5,800 acres of valley floor was covered by open water and about 15,000 acres was covered by marsh vegetation. In July 2001, Franklin Lake had no open water and Ruby Lake had declined to about 4,000 acres.

The hydrologic conditions used to develop the water budget for Ruby Valley are characterized by data collected as part of the overall study of Ruby Valley and other contemporary investigations. Total inflow to Ruby Valley ranges from about 710,000 to nearly 930,000 acre-ft/yr. Precipitation represents the largest inflow component and ranges from about 700,000 acre-ft/yr, based on the Hardman precipitation map, to 910,000 acre-ft/yr, derived from the relation between altitude and location. Estimates of subsurface inflow represent less than 2 percent of the total inflow and range from 10,000 to 16,000 acre-ft/yr.

Estimates of total outflow from Ruby Valley range from about 780,000 to 870,000 acre-ft/yr. Evapotranspiration represents the largest outflow and is subdivided into areas of the mountain block, alluvial slopes, and valley floor. Estimated ET from mountain-block areas that border Ruby Valley is about 270,000 acre-ft/yr. Estimated ET on alluvial slopes in the area of study, where the only source of water is soil moisture from precipitation, is about 180,000 acre-ft/yr. Estimated total ET on the valley floor of Ruby Valley ranges from about 330,000 to 420,000 acre-ft/yr and is comprised from five different land-cover types. These types include areas of natural phreato- phytic and nonphreatophytic vegetation, areas of open water and associated wetlands, wet playas, and areas of irrigated land. Based on estimates from five sites in Ruby Valley, about 170,000 acre-ft/yr of water is consumed by ET in areas of phreatophytic vegetation. Nonphreatophytic vegetation on the valley floor covers about 133,000 acres and is estimated to use about 100,000 to 130,000 acre-ft/yr. ET in areas of open water, associated wetlands, and wet playas ranges from about 48,000 to 100,000 acre-ft/yr. The amount of applied irrigation water that is consumed by ET depends on the application method of irrigation. About 3,800 to 4,500 acre-ft/yr of water is consumed by ET in areas that use center-pivot irrigation and about 7,400 to 11,000 acre- $\mathrm{ft} / \mathrm{yr}$ is consumed in areas that use flood irrigation.

Subsurface outflow northeast toward Clover Valley and southwest toward Long Valley total about 3,000 to 6,400 acre$\mathrm{ft} / \mathrm{yr}$ and represents less than 1 percent of the total outflow from Ruby Valley. These estimates may represent minimum values because some ground water may move through carbonate rocks that is not accounted for in these estimates.

Although the estimated water budget is subject to a number of qualifications and uncertainties, the budget indicates the relative distribution and movement of water. The range in values for several budget components also indicates the uncertainty, some of which may be due to climatic variability, particularly components of precipitation and ET. Uncertainty in the water-budget components could be reduced by collection of additional climatic and hydrologic data.

\section{References Cited}

Allander, K.K., Gortsema, G.C., Hutchinson, D.D., and Schwartzenberger, J.T., 2001, Water resources data, Nevada water year 2000: U.S. Geological Survey Water-Data Report NV-00-1, 570 p.

Bedinger, M.S., Harrill, J.R., and Thomas, J.M., 1984, Maps showing ground-water units and withdrawal, Basin and Range Province, Nevada: U.S. Geological Survey WaterResources Investigations Report 83-4119-A, 10 p., 2 sheets, scale 1:500,000.

Benson, Larry, and Thompson, R.S., 1987, The physical record of lakes in the Great Basin, in Ruddiman, W.F., and Wright, H.E., Jr., eds., The geology of North America, volume K-3, North America and adjacent oceans during the last deglaciation: Boulder, Colo., Geological Society of America, p. 241-260.

Berger, D.L., 1995, Ground-water conditions and effects of mine dewatering in Desert Valley, Humboldt and Pershing Counties, northwestern Nevada, 1962-91: U.S. Geological Survey Water-Resources Investigations Report 95-4119, 94 p. 
Berger, D.L., 2000a, Water budgets for Pine Valley, Carico Lake Valley, and Upper Reese River Valley Hydrographic Areas, middle Humboldt River Basin, north-central Nevada-Methods for estimation and results: U.S. Geological Survey Water-Resources Investigations Report 99-4272, 40 p.

Berger, D.L., 2000b, Water-budget estimates for the 14 hydrographic areas in the middle Humboldt River Basin, north-central Nevada: U.S. Geological Survey WaterResources Investigations Report 00-4168, 55 p.

Berger, D.L., Johnson, M.J., Tumbusch, M.L., and Mackay, Jeffrey, 2001, Estimates of evapotranspiration from the Ruby Lake National Wildlife Refuge area, Ruby Valley, northeast Nevada, May 1999-October 2000: U.S. Geological Survey Water-Resources Investigations Report 01-4234, 38 p.

Berger, D.L., Ross, W.C., Thodal, C.E., and Robledo, A.R., 1997, Hydrogeology and simulated effects of urban development on water resources of Spanish Springs Valley, Washoe County, west-central Nevada, U.S. Geological Survey Water-Resources Investigations Report 96-4297, $80 \mathrm{p}$.

Berris, S.N., Crompton, E.J., Joyner, J.D., and Ryan, Roslyn, 2003, Water resources data, Nevada, water year 2002: U.S. Geological Survey Water-Data Report NV-02-1, 600 p.

Bossong, C.R., Caine, J.S., Stannard, D.I., Flynn, J.L., Stevens, M.R., and Heiny-Dash, J.S., 2003, Hydrologic conditions and assessment of water resources in the Turkey Creek watershed, Jefferson County, Colorado, 1998-2001: U.S. Geological Survey Water-Resources Investigations Report 03-4034, 140 p.

Busenberg, E., and Plummer, L.N., 2000, Dating young groundwater with sulfur hexafluoride: Natural and anthropogenic sources of sulfur hexafluoride: Water Resources Research, v. 36(10), p. 3011-3030.

Cardinalli, J.L., Roach, L.M., Rush, F.E., and Vasey, B.J., comps., 1968, State of Nevada hydrographic areas: Nevada Division of Water Resources Map, scale 1:500,000.

Charlet, D.A., 1996, Atlas of Nevada conifers: Reno, University of Nevada Press, 320 p.

Claassen, H.C., Reddy, M.M., and Halm, D.R., 1989, Use of the chloride ion in determining hydrologic-basin water budgets-A 3-year case study in the San Juan Mountains, Colo., USA.: Journal of Hydrology, v. 85, p. 49-71.

Coats, R.R., 1987, Geology of Elko County, Nevada: Nevada Bureau of Mines and Geology Bulletin 101, 112 p.

Craig, H., 1961, Isotopic variations in natural water: Science, v. 133, p. $1702-1703$.
Csuti, Blair, 1987, Franklin Lake, Nevada, ecological survey: Report from the files of the Great Basin Field Office of the Nature Conservancy, $12 \mathrm{p}$.

Daly, Christopher, Neilson, R.P., and Phillips, D.L., 1994, A statistical-topographic model for mapping climatological precipitation over mountainous terrain: Journal of Applied Meteorology, v. 33, no. 2, p. 140-158.

Dettinger, M.D., 1989, Reconnaissance estimates of natural recharge to desert basins in Nevada, U.S.A., by using chloride-balance calculations: Journal of Hydrology, v. 106, p. $55-78$.

Dudley, W.W., Jr., 1967, Hydrogeology and ground-water flow system of the central Ruby Mountains, Nevada: Urbana, University of Illinois, unpublished doctoral thesis, $107 \mathrm{p}$.

Eakin, T.E., and Maxey, G.B., 1951, Ground water in Ruby Valley, Elko and White Pine Counties, Nevada, in Eakin, T.E., Maxey, G.B., Robinson, T.W., Fredericks, J.C., and Loeltz, O.J., Contributions to the hydrology of eastern Nevada: Nevada State Engineer, Water Resources Bulletin 12, p. 65-93.

Garcia, K.T., Munson, R.H., Spaulding, R.J., and Vasquez, S.L., 2002, Water resources data, Nevada, water year 2001: U.S. Geological Survey Water-Data Report NV-01-1, 528 p.

Glancy, P.A., 1968, Water-resources appraisal of Butte Valley, Elko and White Pine Counties, Nevada: Nevada Division of Water Resources, Reconnaissance Report 49, 50 p.

Hardman, George, 1936, Nevada precipitation and acreages of land by rainfall zones: University of Nevada, Reno, Agricultural Experiment Station report, 10 p. and map.

Hardman, George, and Mason, H.G., 1949, Irrigated lands in Nevada: University of Nevada, Reno, Agricultural Experiment Station Bulletin 183, 57 p.

Harrill, J.R., 1968, Hydrologic response to irrigation pumping in Diamond Valley, Eureka and Elko Counties, Nevada, 1950-65, with a section on Surface water, by R.D. Lamke: Nevada Department of Conservation and Natural Resources, Water Resources Bulletin 35, 85 p.

Harrill, J.R., Gates, J.S., and Thomas, J.M., 1988, Major ground-water flow systems in the Great Basin region of Nevada, Utah, and adjacent states: U.S. Geological Survey Hydrologic Investigations Atlas HA-694-C, 2 sheets.

Heath, R.C., 1983, Basic ground-water hydrology: U.S. Geological Survey Water-Supply Paper 2220, 84 p.

Hem, J.D., 1985, Study and interpretation of chemical characteristics of natural water ( $3 \mathrm{~d}$ ed.): U.S. Geological Survey Water-Supply Paper 2254, 264 p. 
Hess, Ronald, Davis, David, and Boldi, Karen, comps., 2004, Oil and gas well drilled in Nevada listed by township, range, and section: Nevada Bureau of Mines and Geology, accessed January 4, 2005, at URL: <http://www.nbmg.unr. edu/lists/oil/oillisttr.php>.

Hill, J.M., 1916, Notes on some mining districts in eastern Nevada: U.S. Geological Survey Bulletin 648, p. 54-63.

Hose, R.K., and Blake, M.C., Jr., 1976, Geology and mineral resources of White Pine County, Nevada, Part I, Geology: Nevada Bureau of Mines and Geology Bulletin 85, 35 p., $1: 250,000$.

Houghton, J.G., Sakamoto, C.M., and Gifford, R.O., 1975, Nevada's weather and climate: Nevada Bureau of Mines and Geology Special Publications 2, 78 p.

Howard, K.A., 1966a, Large-scale recumbent folding in the metamorphic rocks of the northern Ruby Mountains, Nevada [abs.]: Geological Society of America Special Paper $87,210 \mathrm{p}$.

Howard, K.A., 1966b, Structure of the metamorphic rocks of the northern Ruby Mountains, Nevada [Ph.D. thesis]: New Haven, Conn., Yale University, 302 p.

Howard, K.A., 1971, Paleozoic metasediments in the northern Ruby Mountains, Nevada: Geological Society of America Bulletin, v. 82, no. 1, p. 259-264.

Howard, K.A., 1980, Metamorphic infrastructure in the northern Ruby Mountains, Nevada, in Crittenden, M.D., Jr., Coney, P.J., and Davis, G.H., eds., Metamorphic core complexes: Geological Society of America Memoir 153, p. 335-347.

Johnson, C.A., 1980, Environmental controls on occurrence and chemistry of ground water in a carbonate terrace of eastern Nevada: University of Nevada, Desert Research Institute, publication no. 41066, 101 p.

Maurer, D.K., and Berger, D.L., 1997, Subsurface flow and water yield from watersheds tributary to Eagle Valley Hydrographic Area, west-central Nevada: U.S. Geological Survey Water-Resources Investigations Report 97-4191, $56 \mathrm{p}$.

Maurer, D.K., Berger, D.L., Tumbusch, M.L., and Johnson, M.J., in press, Rates of evapotranspiration, recharge from precipitation beneath selected areas of native vegetation, and streamflow gain and loss in Carson Valley, Douglas County, Nevada, and Alpine County, California: U.S. Geological Survey Scientific Investigations Report 2005-5288. Available at URL: <http://pubs.water.usgs.gov/sir20055288>.
Maurer, D.K., Lopes, T.J., Medina, R.L., and Smith, J.L., 2004a, Hydrogeology and hydrologic landscape regions of Nevada: U.S. Geological Survey Scientific Investigations Report 2004-5131, 35 p.

Maurer, D.K., Watkins, S.A., and Burrows, R.L., 2004b, Updated computations and estimates of streamflows tributary to Carson Valley, Douglas County, Nevada, and Alpine County, California, 1990-2002: U.S. Geological Survey Scientific Investigations Report 2004-5179, 29 p., available at URL: <http://pubs.water.usgs.gov/sir20045179>.

Mifflin, M.D., and Wheat M.M., 1979, Pluvial lakes and estimated pluvial climates of Nevada: Nevada Bureau of Mines and Geology Bulletin 94, 57 p.

Morrison, R.B., 1968, Pluvial lakes, in Fairbridge, R.W., ed., The Encyclopedia of Geomorphology: Reinhold Book Corp., p. 873-883.

National Oceanic and Atmospheric Administration, 2002, Monthly station normals of temperature, precipitation, and heating and cooling degree days, 1971-2000: National Climatic Data Center, Asheville, N.C., Climatography of the United States, no. 81, (Nevada), 26 p.

National Oceanic and Atmospheric Administration, 2005, National Climatic Data Center, Palmer Drought Severity Index: National Oceanic and Atmospheric Administration, accessed March 22, 2005, at URL: <http://www.drought. noaa.gov>.

Natural Resources Conservation Service, 2002, SNOTEL data network: U.S. Department of Agriculture, Natural Resources Conservation Service, accessed March 22, 2002, at URL: <http://www.wcc.nrcs.usda.gov/snow>.

Nevada Revised Statues, 2003, Nevada water laws: Division of Water Resources, Title 48-water (chapters 532-544), 319 p.

Nichols, W.D., 2000, Regional ground-water evapotranspiration and ground-water budgets, Great Basin, Nevada: U.S. Geological Survey Professional Paper 1628, 82 p.

Olmsted, F.H., Glancy, P.A., Harrill, J.R., Rush, F.E., and Van Denburgh, A.S., 1975, Preliminary hydrogeologic appraisal of selected hydrothermal systems in northern and central Nevada: U.S. Geological Survey Open-File Report 75-56, $267 \mathrm{p}$.

Plume, R.W., 1996, Hydrogeologic framework of the Great Basin region of Nevada, Utah, and adjacent states: U.S. Geological Survey Professional Paper 1409-B, 64 p. 
Plume, R.W., 2003, Ground-water use, locations of production wells, and areas irrigated using ground water in 1998, middle Humboldt River Basin, north-central Nevada: U.S. Geological Survey Water-Resources Investigations Report 03-4227, $16 \mathrm{p}$.

Prudic, D.E., Harrill, J.R., and Burbey, T.J., 1995, Conceptual evaluation of regional ground-water flow in the carbonaterock province of the Great Basin, Nevada, Utah, and adjacent states: U.S. Geological Survey Professional Paper 1409-D, 102 p.

Prudic, D.E., and Herman, M.E., 1996, Ground-water flow and simulated effects of development in Paradise Valley, a basin tributary to the Humboldt River in Humboldt County, Nevada: U.S. Geological Survey Professional Paper 1409-F, $92 \mathrm{p}$.

Reiner, S.R., Laczniak, R.J., DeMeo, G.A., Smith, J.L., Elliott, P.E., Nylund, W.E., and Fridrich, C.J., 2002, Ground-water discharge determined from measurements of evapotranspiration, other available hydrologic components, and shallow water-level changes, Oasis Valley, Nye County, Nevada: U.S. Geological Survey Water-Resources Investigations Report 01-4239, 65 p.

Riggs, H.C., and Moore, D.O., 1965, A method of estimating mean runoff from ungaged basins in mountainous regions, in Geological Survey Research 1965: U.S. Geological Survey Professional Paper 525-D, p. D199-D202.

Rush, F.E., 1968, Index of hydrographic areas in Nevada: Nevada Division of Water Resources, Information Report 6, $38 \mathrm{p}$.

Rush, F.E., and Everett, D.E., 1966, Water-resources appraisal of the Huntington Valley area, Elko and White Pine Counties, Nevada: Nevada Department of Conservation and Natural Resources, Water Resources - Reconnaissance Report 35, $37 \mathrm{p}$.

Sharp, R.P., 1938, Pleistocene glaciation in the RubyEast Humboldt Range, northeastern Nevada: Journal of Geomorphology, v. 1, no. 4, p. 296-323.

Sharp, R.P., 1939a, Basin-range structure of the Ruby-East Humboldt Range, northeastern Nevada: Geological Society of America Bulletin, v. 50, p. 881-919.

Sharp, R.P., 1939b, The Miocene Humboldt Formation in northeastern Nevada: Journal of Geology, v. 47, p. 133-160.

Sharp, R.P., 1940, Geomorphology of the Ruby-East Humboldt Range, Nevada: Geological Society of America Bulletin, v. 51, p. 337-371.

Sharp, R.P., 1942, Stratigraphy and structure of the southern Ruby Mountains, Nevada: Nevada: Geological Society of America Bulletin, v. 53, p. 647-690.
Smith, W.P., 1986, Reconstruction of precipitation in northeastern Nevada using tree rings, 1600-1982: Journal of Climate and Applied Meteorology, v. 25, no. 9, p. 12551263.

Smith, J.F., Jr., and Ketner, K.B., 1976, Stratigraphy of postPaleozoic rocks and summary of resources in the CarlinPinon Range area, Nevada, with a section on Aeromagnetic survey, by D.R. Mabey: U.S. Geological Survey Professional Paper 867-B, 48 p.

Stewart, J.H., 1980, Geology of Nevada: Nevada Bureau of Mines and Geology Special Publication 4, 136 p.

Stewart, J.H., and Carlson, J.E., 1978, Geologic map of Nevada: U.S. Geological Survey, scale 1:500,000.

Stewart, J.H., and Poole, F.G., 1974, Lower Paleozoic and uppermost Precambrian Cordilleran miogeocline, Great Basin, Western United States, in Dickinson, W.R., ed., Tectonics and sedimentation: Society of Economic Paleontologists and Mineralogists Special Publication 22, p. 28-57.

Taylor, G.H., 1940, Memorandum relative to ground water in Ruby Valley, Nevada (typewritten report in files of USGS), $9 \mathrm{p}$.

Thomas, J.M., Mason, J.L., and Crabtree, J.D., 1986, Groundwater levels in the Great Basin region of Nevada, Utah, and adjacent states: U.S. Geological Survey Hydrologic Investigations Atlas HA-694-B, 2 sheets, scale 1:1,000,000.

Thompson, R.S., 1992, Late Quaternary environments in Ruby Valley, Nevada: Quaternary Research, v. 37, p. 1-5.

U.S. Environmental Protection Agency, 2005, List of contaminants \& their MCLs: U.S. Environmental Protection Agency, National drinking water regulations, accessed May 20, 2005, at URL: <http://www.epa.gov/safewater/mcl. html\#mcls>.

U.S. Geological Survey, 2001, USGS geographic data download-Digital line graph (DLG) digital elevation model (DEM) distribution update: U.S. Geological Survey topographic map series accessed 2001, available at URL: $<$ http://edc.usgs.gov/geodata/>.

Welch, A.H., and Preissler, A.M., 1990, Geothermal resources of the western arm of the Black Rock Desert, northwestern Nevada-Part II, Aqueous geochemistry and hydrology: U.S. Geological Survey Water-Resources Investigations Report 87-4062, 91 p. 


\section{אב}

色

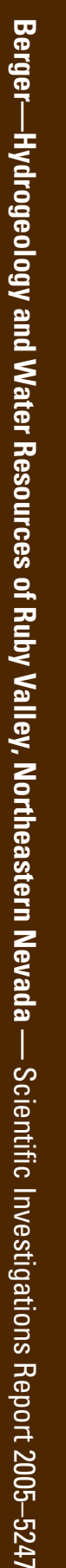

